\title{
Rainfall Distribution Functions for Irrigation Scheduling: Calculation Procedures Following Site of Olive (Olea europaea L.) Cultivation and Growing Periods
}

\author{
Chiraz Masmoudi-Charfi ${ }^{*}$, Hamadi Habaieb ${ }^{2}$ \\ ${ }^{1}$ Institution of Agriculture Research \& High Education, Tunis, Tunisia \\ ${ }^{2}$ National Institute of Agronomy, Tunis, Tunisia \\ Email: ${ }^{*}$ masmoudi.chiraz@yahoo.fr
}

Received 9 May 2014; revised 6 June 2014; accepted 23 June 2014

Copyright (C) 2014 by authors and Scientific Research Publishing Inc. This work is licensed under the Creative Commons Attribution International License (CC BY). http://creativecommons.org/licenses/by/4.0/

(c) (7) Open Access

\section{Abstract}

In Tunisia $\left(36.5^{\circ} \mathrm{N}, 10.2^{\circ} \mathrm{E}\right.$, Alt. $\left.10 \mathrm{~m}\right)$, rainfall is the major factor governing olive production. It is characterized by large variability in time and space, making yields of olive trees highly dependent on the amount of water received and timing. Thus, improvement of olive productivity by irrigation is necessary. This study aimed to determine the crop water needs of olive orchards and the rainfall frequencies at which they are covered following age and sites of olive production. For this purpose, the rainfall distribution functions are established for different cities of Tunisia (Tunis, Bizerte, Béja, Nabeul, Sidi Bouzid, Gabes and Sousse). For all sites and growing periods, the reference evapotranspiration $\left(\mathrm{ET}_{0}\right)$ was computed by using several formulas. Their performance against the Penman Monteith (PM) method was evaluated graphically and statistically in all considered cities in order to evaluate their accuracy for better adapting them to the existing environmental conditions, particularly when data are missing to compute $\mathrm{ET}_{0}-\mathrm{PM}$. Results presented herein show that the estimated $\mathrm{ET}_{0}$ values strongly correlate with $\mathrm{ET}_{0}-\mathrm{PM}$ at all sites and formulas with $r$ values up to 0.88 . Particularly, the methods of Turc and Ivanov appropriately predict the

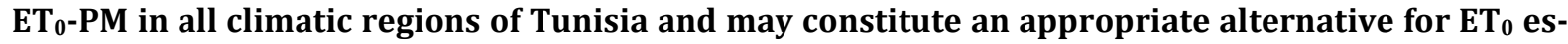
timation when data are missing to compute $\mathrm{ET}_{0}-\mathrm{PM}$. However, although the Turc method performs well with all climatic zones, arid and semi-arid, in western, northern and coastal areas of Tunisia, the Ivanov method appears to be more appropriate to the northern areas (Béja and Bizerte) characterized by semi arid climate and having annual rainfall of up to $450 \mathrm{~mm}$, though a poorer agreement was found when using the Eagleman formula. Estimates of $\mathrm{ET}_{0}$ by using the Hargreave-Samani (HS) formula for the east-southern area (Gabes) characterised by arid climate show satisfactory agreement with $\mathrm{ET}_{0}-\mathrm{PM}$ estimates, corroborating previous findings reporting

\footnotetext{
${ }^{*}$ Corresponding author.

How to cite this paper: Masmoudi-Charfi, C. and Habaieb, H. (2014) Rainfall Distribution Functions for Irrigation Scheduling: Calculation Procedures Following Site of Olive (Olea europaea L.) Cultivation and Growing Periods. American Journal of Plant Sciences, 5, 2094-2133. http://dx.doi.org/10.4236/ajps.2014.513224
} 
that the HS method performs well in most climatic regions, with the exception of humid areas where it tends to overestimate $\mathrm{ET}_{0}$. It appears also that at a given site, the most appropriate method for $\mathrm{ET}_{0}$ estimation at annual scale may be different from that giving the best value of $\mathrm{ET}_{0}$ when considering the growing stages of the olive tree. The formula of Turc, although it was appropriate when estimating the annual $\mathbf{E T}_{0}$ value for Sousse, it wasn't adequate at seasonal scale. Adversely, although the method of $B C$ is suitable for stages $1,2,4$ and 5 at Sousse, the appropriate method for the overall cycle is that of Turc. Results also show that the average annual value of $\mathrm{ET}_{0}$-PM calculated by using full datasets from January to December is well correlated to the maximum and minimum daily estimates with $r$ values ranging between 0.70 and 0.83 . These variations indicate that there is no weather-based evapotranspiration equation that can be expected to predict evapotranspiration perfectly under every climatic situation due to simplification in formulation and errors in data measurement. Nevertheless we can say that when data are missing, $\mathrm{ET}_{0}$ can be estimated with a specific formula, suggesting that of Turc for Tunis, Sidi Bouzid, Sousse and Béja at annual scale despite of their appartenance to different climatic regions, while the method of Ivanov is quite valuable for Bizerte and Nabeul. Determination of the crop evapotranspiration (ETC) on the basis of $\mathrm{ET}_{0}$-PM computations following age and the growing periods show positive values of (ETC-P) at annual scale for Tunis, Nabeul, Sousse Bizerte and Beja when young olive plantations are considered, but for old trees, values are positive only for Tunis, Bizerte and Béja. Seasonal differences between ETC and $P$ (rainfall) recorded during the irrigation period are negative even for young plantations. The lowest and highest deficits are observed at Béja and Gabes cities, respectively. The rainiest periods are December-February for Béja, Tunis and Bizerte and September-November for the other sites with similar trends for rainfall frequency (F). The driest period is that of July-August for all sites, with $F$ values exceeding 0.9 in most cases. Only $10 \%$ of water needs are supplied by rainfall during this period of fruit development even for one year old orchards. Therefore, irrigation is needed all time for adult trees even at the rainiest locations. For young plantations, irrigation becomes necessary beginning from the second period of tree development, i.e. April-June for Bizerte, Béja, Nabeul and Tunis since the early spring period for both young and old plants for Gabes and Sidi-Bouzid. It appears from this analysis based on the seasonal rainfall frequencies and water needs computed with the PM-formula, that there is a need for irrigating olive plantations aging more than 5 years in most case studies and especially when olive is cultivated in the western areas of Tunisia. Irrigation is needed during the growing fruit period but also during the other seasons, when shoots grow. Results also indicate that the use of no adequate method to estimate $\mathrm{ET}_{0}$ allowed overestimating or underestimating of water requirements. So it is desirable to have a method that estimates ET consistently well and future research is needed to reconcile which should be the standard method of calculating the change in the crop coefficient over time. However, despite a quite good performance of the PM-equation in most applications, particularly when it is used for irrigation scheduling purposes, some problems may appear because of lack of local information on values and determination of the effective rainfall. In conclusion we can say that on the basis of the results produced, we can decide for each region and growing period if complementary irrigation is needed or not. Indicative amounts are given for each case study. Also, it appears to our best knowledge that this work with that of Nasr (2002) [1] is the only one that has estimated $\mathrm{ET}_{0}$ for the whole country using PM-ET $\mathrm{P}_{0}$ compared to other empirical methods, but we didn't test the possible advantages in using calibrated values for the radiation adjustment coefficient or temperature adjustment for dew point temperature estimation as proposed by Allen (1996) [2]. This calibration is therefore a line to be explored. Additional research is needed on developing crop coefficients that use the Penman-Monteith equation when calculating ET and a standardized method of calculating the time base for the crop coefficients preferably based on a growing degree day concept.

\section{Keywords}

Methods of ET $_{0}$ Computation, FAO-PM Method, Climatic Water Deficit, Irrigation Application, Rainfall Frequency 


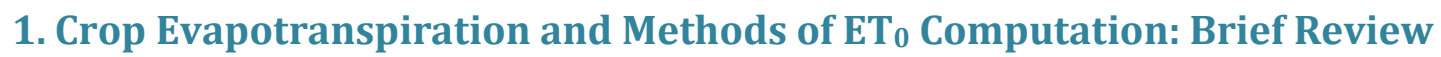

Most water absorbed by roots is lost through leaf stomata. This process is driven by the climatic demand and involves the need of measuring many biological and environmental variables like evapotranspiration. A large number of formulas have been developed and/or improved from 1942 to 2005 to compute the monthly or the seasonal "consumptive water use" later termed reference evapotranspiration $\left(\mathrm{ET}_{0}\right)$, starting with the BlaneyCriddle formula (BC) method and ending with the Penman-Monteith equation (PM) [3]-[6].

Empirical methods were primarily based on solar radiation (Turc, 1961; Christiansen-Hargreaves, 1969; Hargreaves-Samani, 1985), temperature (Blaney-Criddle, original and modified, 1950) and relative humidity (Ivanov, 1954; Eagleman, 1967). The formulas of Penman (Penman Original, 1963) and FAO-PM [7] [8] are based on combination theory and necessitate intermediary calculi, involving simultaneous measurements of radiation, air temperature, humidity and wind speed. Calculation procedures are described in Rana and Katerji (2000) and Habaieb and Masmoudi-Charfi (2003) [6]-[9] and recently summarized by Sammis et al. (2011) [10].

Many of these formulas have been used for irrigation and water rights management and yield prediction, but some of them provided errors and large uncertainities because most evapotranspiration available data are site specific and are difficult to apply to other situations. For this reason a consultation of experts and researchers, with the International Commission for Irrigation and Drainage and the World Meteorological Organization, have been organized by the FAO in the 90th in order to review the methodologies and procedures adopted for determinating the crop water requirements $(E T C)$. This consultation considered the PM-model as the most advanced method for ETc determination in commercial orchards. It is aimed to define the grass reference evapotranspiration, i.e., the rate of evapotranspiration from an hypothetical crop approximately resembling the evapotranspiration from an extensive surface of a disease-free green well-watered grass cover of uniform height, actively growing, completely shading the ground, and with adequate water and nutrient supply. Though, it is selected as the method by which the evapotranspiration of this reference surface $\left(\mathrm{ET}_{0}\right)$ can be unambiguously determined, providing consistent ET0 values in all regions and climates. Indeed, as the methodology of $\mathrm{ET}_{0}$-PM estimation was successfully applied at different time scales in various climatic regions of the world [11]-[24], it was adopted since the year 1998 as the referenced method [8].

As redefined by The Food and Agricultural Organization of United Nations [8], the PM-equation overcomes shortcomings of the previous FAO Penman method, providing values of $\mathrm{ET}_{0}$ more consistent with actual crop water use data worldwide and was found to be more consistent over a wider range of climatic conditions than other equations [16]. It became the American Society of Civil Engineers (ASCE) Standardized Reference ET equation and the current recommended equation to calculate the evapotranspiration rate from non-water stressed crop, i.e., the evaporation power of the atmosphere which is expressed by the reference crop evapotranspiration $\left(\mathrm{ET}_{0}\right)$.

The PM-equation has two components: the radiation component controls ET by providing energy to drive the ET process [20] and the wind and vapor pressure deficit component which "controls the rate of transport of water vapor from the plant and soil surface and the capacity of the air to absorb water vapor". But estimating all these parameters needs auxiliary sub-models locally calibrated or parameterizations for conductances [13]. This implies many uncertainties which are introduced through the parameterization of the other variables [25]. In addition, as most available evapotranspiration data are site specific and are difficult to apply to other situations, the panel of experts developed a simplified way to deal with evapotranspiration dependence on climate by relating it to standard reference evapotranspiration $\left(\mathrm{ET}_{0}\right)$ by the crop coefficient, $K_{c}$, which is defined as the ratio of the crop evapotranspiration to the reference evapotranspiration as: $K_{c}=$ crop ETc/grass ET, where ET is the maximum daily, monthly or seasonal evapotranspiration determined under non-stressed conditions. It is an empirical seasonal factor relating the seasonal plant water usage for a specific crop to the total seasonal consumptive water use factor generated under experimental conditions. $K_{c}$ depends on the development rate of the crop and varies following year, season, the amount of water available to roots and the effective transpiring leaf area which was used in the PM-model to estimate daily tree transpiration of whole trees [8] [12] [26]-[28]. But as optimal conditions are difficult to realize, crop coefficients were taken as the ratio of evapotranspiration of well-watered orchards.

However, although the PM-method is considered as the most rational and elaborated approach, it could not be used for reliable estimation of $\mathrm{ET}_{0}$ with incomplete series of climatic data. The lack of full weather datasets in many parts of the world, particularly in remote areas, limits the application of $\mathrm{ET}_{0}$-PM, which is a major prob- 
lem. Indeed, computation of $\mathrm{ET}_{0}$ with the PM-equation requires a large number of climatic data, which are often very scanty, forcing the user to choose some other alternatives. Alternative accurate approaches requiring limited data has led to a huge number of related studies focusing various climates [15]-[32]. These procedures have been tested by Nandagiri and Kovoor (2005) [33].

Basing upon former studies to compare the performance of ET temperature methods, mainly the study made by Jensen et al. (1990 and 1997) [27]-[34], when full weather data are lacking, $\mathrm{ET}_{0}$ can be estimated either using the empirical Hargreaves-Samani (HS) equation [4], or empirically estimating $R_{n}$, VPD and $U_{2}$ for using in the $\mathrm{ET}_{0}-\mathrm{PM}$ equation, including using data from neighbour weather stations [16]. Various ET temperature methods were then excluded, particularly the ET climatic equation of Thornthwaite (1948) [35], that largely underestimates $\mathrm{ET}_{0}$ comparatively to $\mathrm{ET}_{0}-\mathrm{PM}$ [36]. In both aforementioned methods the minimum set of data required consists of $T_{\max }$ and $T_{\min }$. The latter approach for using the $\mathrm{ET}_{0}-\mathrm{PM}$ with only $\mathrm{T}_{\max }$ and $\mathrm{T}_{\min }$ is called PM temperature (PMT) method and is also referred in literature as reduced set PM method [32]. Both the HS and PMT methods have received a continuous attention from research contrarily to the use of neighbour weather data. The recent methodology reported by Martí and Zarzo (2012) [37] based on principal component analysis to estimate $\mathrm{ET}_{0}$ when no local climatic inputs are available may provide new developments in this domain.

The $\mathrm{ET}_{0}-\mathrm{PM}$ is widely used to manage irrigation of orchards characterized by incomplete soil cover. Irrigation water supplies are computed on the basis of the crop evapotranspiration (ETc) and rainfall amounts (R). In Tunisia $\left(36.5^{\circ} \mathrm{N}, 10.2^{\circ} \mathrm{E}\right.$, Alt. $\left.10 \mathrm{~m}\right)$, rainfall is the main fresh water resource providing annually $36 \mathrm{Km}^{3}$ of water in average, of which only $3 \mathrm{~km}^{3}$ could be potentially collected as runoff water in large dams [38]. Large spatio-temporal variability characterise rainfall distribution with annual amounts ranging between $1500 \mathrm{~mm}$ in the extreme north of the country (Mogods mountains) and less than $80 \mathrm{~mm}$ in the southern area (Sahara). Non-arid area is estimated only at $37,000 \mathrm{~km}^{2}$ (24\%), arid area at 55,000 $\mathrm{km}^{2}$ (35\%) and desert at 63,000 $\mathrm{km}^{2}$ (41\%) [39] [40]. Renewable groundwater resources are estimated at $1.7 \mathrm{~km}^{3}$ and mostly used (83\%) for agriculture [41]. About 500,000 ha of annual and perennial crops are irrigated permanently, amongst 66,000 ha of olives beneficiate regularly of complementary irrigation.

Olive (Olea europaea L.) is the main component of our agricultural system covering one third of the agricultural area which approximates 1400,000 ha. Most plantations are rainfed, receiving annually no more than 250 $\mathrm{mm}$ of rainfall. A major part of these falls is received during the autumn and winter (quiescent period) seasons and only $25 \%$ of this amount and perhaps less is profitable to the growing fruits (May to October), that's why fruit size and olive production remain highly dependent on water provided during that period and particularly in the centre and southern areas [42]-[44]. Yields fluctuate from year to year between 60,000 and 300,000 tons as well as the amount of extracted oil (16\% to $26 \%$ ). This situation is very uncomfortable for both orchadists and the government because olive benefits are the main financial resource for agriculture, and Tunisia has to provide obviously thousand tons of olive oil each year for exportation to the EU, which is a strategic partner.

Supplemental irrigation [40] of olive orchards has emerged during the last few decades as an appropriate practice that has the potential to improve their productivity and stabilize yields by reducing spatial and temporal production variability. It has been adopted in different parts of Tunisia, and even institutionalized as a major strategy to respond to growing water scarcity in the irrigated areas and at the same time to increase crop productivity in traditionally rainfed plantations. Furthermore, the Tunisian government has taken since the 90th through its financial and development programs to develop many water conservation strategies as building important hydraulic catchments [39]-[41]. Also, the government encourages farmers to densify the traditional plantations in order to increase their benefits and oil production and to plant olive trees at higher densities, by distributing in some cases free cuttings and N-fertilizers. All kind of waters, fresh, brakish [45] and even margines and waste waters [46] are used. With appropriate horticultural practices, olive production has risen significantly during this last decade, but crops still suffer from a large gap between applying the correct water needs and the optimal production because of summer water shortage and cyclic droughts [42]-[40] [47]-[49]. That's why, other methods and technologies like assisted drip irrigation [50]-[52], strategies of deficit irrigation [51] [53]-[55] and partial root irrigation [56] [57], fertigation, high yielding cultivars grown with high levels of input [58] [59], but also innovative techniques that ensure the best use of natural precipitation, should be promoted to improve the performance of the used practices. However, due to the limited available water resources, development of techniques and methods should target at the most profitable areas where the allocation of irrigation water could be optimized.

Consequently, as olive farming becomes more intensive, crops require greater economical inputs and the 
changes accompanying the new cultivation systems have revealed a lack of knowledge about management of these orchards. Many problems erase at field level particularly when irrigating them. A large number of orchardists practice irrigation during the high fruited years independently of tree age, LAI and soil coverage increases. Thus, the amount of water distributed to the orchard may not meet its seasonal water needs and sometimes, lead to a loss of large amounts of water, low water use efficiencies, low growth rates and even dratistic yields. Negative effects appear when water shortage occurs during the critical stages of flower differenciation (February) and fruit growth (June-September), but also during the period of flower induction, occurring during the previous summer. So, because fruits are produced on one year old shoots which elongates during the last year [60]-[62], water should be available during all these stages over two growing seasons to cover water needs with regard to the importance of each one of the physiological process involved during fruit development [63].

In many studies carried out in Tunisia [64]-[69] [52] [70] and elsewhere around the Mediterramean countries [14] [71]-[77], irrigation is applied as a compulsory practice when the tree is the most responsive to water. These works sought to evaluate the potential of using different irrigation amounts to complement rainfall. Results show that in environments characterized by alternating wet and dry seasons, adding small amounts of water during the growing season can increase water productivity many-fold. This potential of supplemental irrigation must be explored to make better use of the limited resources available. Other results show that olive production was almost unchanged when water supply increased up to $300 \mathrm{~mm}$. This is well traduced by some quantitative relationships established between production and water supplies [47] [69] [57] and well described in the recent paper "Manuel d'Irrigation de l'Olivier, Techniques et Applications", published in Tunisia by Masmoudi-Charfi et al. (2012) [78].

Adequate irrigation management requires an accurate estimation of the whole orchard water losses [6] [13] [79]-[82]. This has been measured in olive plantations by using the water balance method [77] [80] [81] [83] and lysimeters [84] providing in situ measurements of the actual water used by plants cultivated under field conditions. This involves estimation of water used at specific time and location as well as the relationship between water consumption and biomass production [57] [69] [85] and its dependency with climatic data and soil coverage [69] [77]. But, when these values are applied at field level, some problems may arise inherent to the spatial representativeness of measurements. Necessarily, the field should be cultivated under the same conditions.

Nowadays, the general approach used to calculate the water requirements of olive orchards is the crop evapotranspiration ET [11] [13] [29] [68] [76] [77] [81] [86], a term more descriptive of the water sources involved, which are the amounts of water evaporated from the soil (E) and transpired by the plant (T) per unit area. These processes occur simultaneously and there is no easy way of distinguishing between them [8] [12] [13]. Plant evaporation measurements named transpiration $(\mathrm{T})$ are difficult to perform and many parameters should be taken into account [11] [49] [83] [84] [87] [88]. Errors or/and consistent changes may arise [16] [25] following age, the anatomy of trees and their vigor, soil water availability and the evaporative demand. If water is not limiting factor, transpiration will be conditioned by leaf area. This may result in a problem of representativeness, since well developed olive trees, shading a large area may provide within the same orchard higher transpiration rates. Moreno et al., (1996), Fernandez et al., (2001) and Abid-Karray (2006) [14] [89] [90] measured this component by the heat pulse technique of Granier (1985) [91]. In Tunisia, Masmoudi-Charfi et al. (2013) [55], showed that tree transpiration of young olive trees cv., Chétoui, approximates 50\% ETc. For soil evaporation, many alternative methods and models were proposed since the 70th [92]-[94]. However, although this component is theoretically well defined, it is difficult to measure for orchards and isolated trees. Most models used for this purpose are based on the fraction of solar radiation reaching the soil surface, which decreases over the growing period as the crop develops. Some attempts should be made to take into account the special inhomogeneity of the environment under the tree [81]. Works carried out in Centre Tunisia on ten years old trees of cultivars Picholine and Meski have shown that soil evaporation equals to 53\% ETC [51]. In other studies made in Spain these components were measured under olive orchards with microlysimeters [94], while the approach developed by Villalobos et al. (2000) [12] is based on the PM-equation [8] [16] with the use of crop coefficients, taken equal to 0.3 0.4 for young trees and ranging between 0.5 and 0.7 for adult plants [95]. Specific values were recently determined in Tunisia for adult trees by Braham and Boussadia (2013) [96] for the period of flowering and fruit set.

This study was carried out in several geographical sites of Tunisia covering the most common regions of olive cultivation, which are characterized by different climates. The main objectives are: 1) to evaluate the potential and accuracy of different $\mathrm{ET}_{0}$ calculation formulas for better adapting them to the existing environmental conditions; 
2) to define for each location the most appropriate formula to determine $\mathrm{ET}_{0}$ and 3) to determine the amount of irrigation application to olive orchards depending on seasonal rainfall amounts, tree age and the growing stages through the establishment of the rainfall distribution functions for each growing period and location. These objectives are set to support a wide range of irrigation management and water resources applications for use in regions where weather data are missing, incomplete or of questionable quality. For each site, the comparative study between $\mathrm{ET}_{0}$-PM and the other estimates, allowed us to choose the formula that gives the most valuable values for a specific city using a limited number of climatic data.

\section{Materials and Methods}

\subsection{Areas of Olive Cultivation and Sites of Study}

In Tunisia olive trees are mostly present in the center and southern regions of the country, contributing with $72 \%$ in number and $88 \%$ in area (Table 1).

Olive is cultivated under different growing environments, systems (rainfed, irrigated) and densities (17 to 1250 trees/ha). Soil is generally clay-loamy in the north, where Mediterranean climate prevail, and salty in the centre and southern regions, characterized by hard and dry conditions with absolute temperature exceeding $40^{\circ} \mathrm{C}$ during the summer months. Fresh water used for irrigation is available in the north and becomes scarcer and brackish elsewhere. Deep resources are found in the southern areas. Water is supplied to olive orchards during the dry season from May to October. Drip irrigation concerns less than $20 \%$ of plantations. Cities concerned with this study and their coordinates (Lat. $36^{\circ}$ to $38^{\circ}$, Long. $8^{\circ}$ to $11^{\circ}$, Alt. $2 \mathrm{~m}$ to $314 \mathrm{~m}$ ) are shown in Table 2 and Figure 1.

Table 1. Distribution of olive trees in Tunisia.

\begin{tabular}{ccc}
\hline Area & \% of total number & \% of total area \\
\hline North & 28 & 12 \\
Center & 60 & 68 \\
South & 12 & 20 \\
Total & $57,000,000$ trees & $1,400,000$ ha \\
\hline
\end{tabular}

Table 2. Coordinates of the studied cities.

\begin{tabular}{|c|c|c|c|c|c|c|}
\hline Site & Localization & Main crops & $\%$ & agriculture & area & (\%) Olive tree area \\
\hline & & & Vegetables & Fruit trees & Cereals & \\
\hline Nabeul & $\begin{array}{c}\text { LAT: } 36^{\circ} 85^{\prime} \mathrm{N} \\
\text { LON: } 11^{\circ} 08^{\prime} \mathrm{E}, \text { ALT: } 30 \mathrm{~m}\end{array}$ & Fruit trees, vine, vegetables & 53.1 & 32.3 & & 9.3 \\
\hline Sousse & $\begin{array}{c}\text { LAT: } 35^{\circ} 76^{\prime} \mathrm{N} \\
\text { LON: } 10^{\circ} 75^{\prime} \mathrm{E}, \mathrm{ALT}: 2 \mathrm{~m}\end{array}$ & Fruit trees and vegetables & 83.2 & & & 9.0 \\
\hline Sidi Bouzid & $\begin{array}{c}\text { LAT: } 34^{\circ} 41^{\prime} \mathrm{N} \\
\text { LON: } 8^{\circ} 81^{\prime} \mathrm{E}, \text { ALT: } 314 \mathrm{~m}\end{array}$ & Fruit trees, vine, wheat, vegetables & & 48.2 & 19.6 & 16.2 \\
\hline Gabes & $\begin{array}{c}\text { LAT: } 33^{\circ} 88^{\prime} \mathrm{N} \\
\text { LON: } 10^{\circ} 10^{\prime} \mathrm{E}, \mathrm{ALT}: 5 \mathrm{~m}\end{array}$ & Fruit trees, vegetables & 29.6 & 47.2 & & 3.2 \\
\hline Tunis & $\begin{array}{c}\text { LAT: } 36^{\circ} 83^{\prime} \mathrm{N} \\
\text { LON: } 10^{\circ} 23^{\prime} \mathrm{E}, \mathrm{ALT}: 4 \mathrm{~m}\end{array}$ & Fruit trees, vine, vegetables & 48.9 & 35.3 & & 10.4 \\
\hline Béjà & $\begin{array}{c}\text { LAT: } 36^{\circ} 48^{\prime} \mathrm{N} \\
\text { LON: } 8^{\circ} 8^{\prime} \mathrm{E}, \mathrm{ALT}: 144 \mathrm{~m}\end{array}$ & Wheat/Annual crops/fruit trees & & 27.1 & 36.9 & 18.7 \\
\hline Bizerte & $\begin{array}{c}\text { LAT: } 37^{\circ} 25^{\prime} \mathrm{N} \\
\text { LON: } 09^{\circ} 8^{\prime} \mathrm{E}, \text { ALT: } 3 \mathrm{~m}\end{array}$ & Fruit trees, vine, annual crops & 48.3 & 24.0 & & 10.5 \\
\hline Tunisia & & Olive trees and Cereals & 30.8 & 40.0 & 14.2 & $1,400,000$ ha \\
\hline
\end{tabular}

NB: fruit trees including olive trees. Remarks: 1. Although Sfax is the main region of olive cultivation it was not considered in the results because the climatic data are incomplete. 2. Climatic data used for the city of Sousse were recorded with an automatic climatic station located in Monastir, which is a locality of Sousse. 


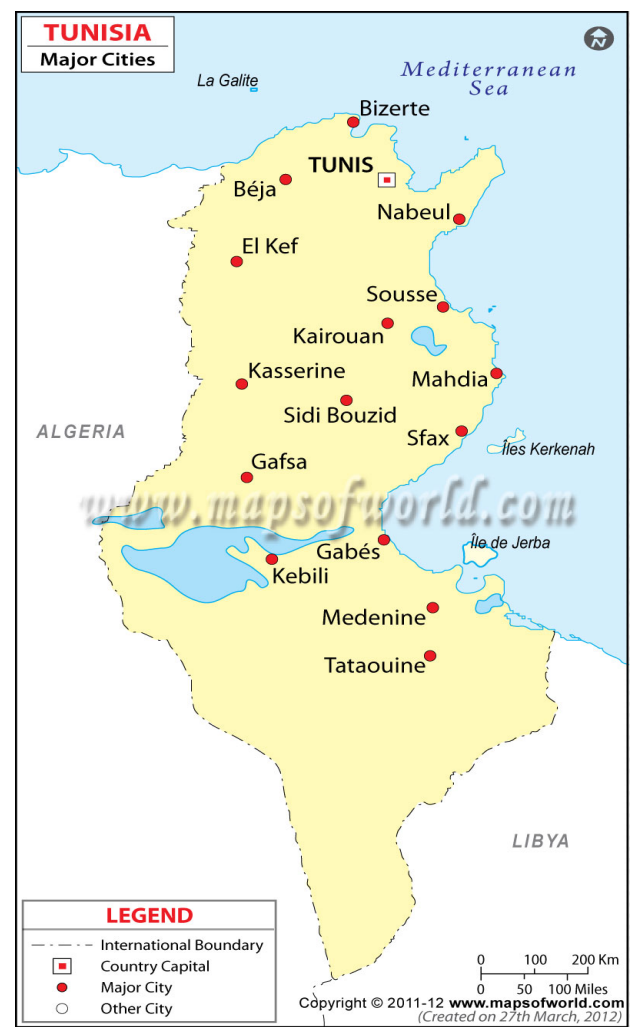

Figure 1. Cities of Tunisia.

Cities of Béja, Tunis, Bizerte and Nabeul are all situated in the North of the country, while Sousse and Sidi Bouzid are located in the Center, and Sfax and Gabes are both coastal sites of South Tunisia.

\subsection{Metdology}

\subsubsection{Steps of Work}

The following steps were followed in this study:

1) Computation of the monthly reference evapotranspiration $\left(\mathrm{ET}_{0}, \mathrm{~mm}\right)$ by using several formulas, comparing estimates to $\mathrm{ET}_{0}$-PM computations;

2) Estimation of the crop evapotranspiration $(E T c, \mathrm{~mm})$ following age and the growing periods;

3) Establishment of the rainfall distribution functions for all growing periods and cites;

4) Visualizing $E T c$ values on the rainfall distribution graphs;

5) Computing the climatic deficit (P-ETc) and determination of the irrigation water amounts (I, mm) following tree age and site.

On the basis of the results produced, we have to decide for each region and period of growth if complementary irrigation is needed or not. Indicative amounts are given for each case study.

\subsubsection{Climatic Variables}

Climatic data were provided by the National Institute of Meteorology (INM) website [92], covering many years (Table 3). Data used for this study are maximum and minimum temperatures $\left(\mathrm{T}_{\max }\right.$ and $\left.\mathrm{T}_{\min },{ }^{\circ} \mathrm{C}\right)$, maximum and minimum relative humidity $\left(\mathrm{RH}_{\max }\right.$ and $\left.\mathrm{RH}_{\min }, \%\right)$, maximum (N, hours/day) and actual sunshine durations (n, hours/month), wind speed measured at $2 \mathrm{~m}$ height $\left(\mathrm{U}_{2}, \mathrm{~m} / \mathrm{s}\right)$ and atmospheric radiation $\left(\mathrm{R}_{\mathrm{a}}, \mathrm{Mj} / \mathrm{m}^{2} / \mathrm{day}\right)$. The majority of the selected cities have the longest and nearly complete data records for the requested period.

Rainfall records are averages of 99 years-long-period (1901-2000). Values are presented in Figure 2 following the regions and the growing periods of olive trees.

Annual rainfall amounts ranged approximately between $200 \mathrm{~mm}$ at Gabes, an east-southern area of Tunisia and $600 \mathrm{~mm}$ at Béja and Bizerte which are continental and coastal areas located in the western and northern areas of 


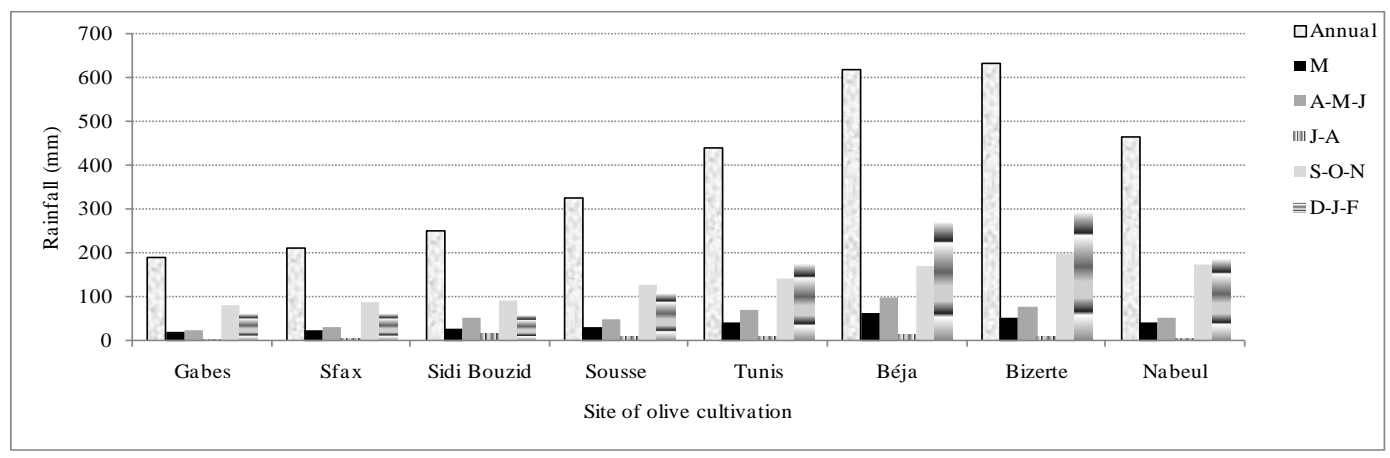

Figure 2. Rainfall amounts (P, mm) recorded in Tunisia following the growing period and sites of olive cultivation. Data are averages computed over 99 years-long-period between years 1901 and 2000.

Table 3. Climatic data recorded at the studied cities (INM, 2013) [97].

\begin{tabular}{|c|c|c|c|c|c|c|c|}
\hline & Tunis & Nabeul & SB & Béja & Gabes & Bizerte & Monastir \\
\hline $\mathrm{T}_{\min }\left({ }^{\circ} \mathrm{C}\right)$ & 13.4 & 15.1 & 12.5 & 10.8 & 162 & 13.1 & 15.2 \\
\hline $\mathrm{T}_{\max }{ }^{\circ} \mathrm{C}$ & 23.5 & 22.7 & 25.3 & 239 & 243 & 22.6 & 24.0 \\
\hline $\mathrm{U}_{2}(\mathrm{~m} / \mathrm{s})$ & 4.2 & 3.0 & 2.8 & 42 & 34 & 3.9 & 4.5 \\
\hline es (mb) & 2.3 & 2.4 & 2.5 & 23 & 26 & 2.2 & 2.5 \\
\hline $\mathrm{R}_{\mathrm{a}}\left(\mathrm{Mj} / \mathrm{m}^{2} /\right.$ day $)$ & 29.3 & 29.3 & 30.3 & 296 & 303 & 29.2 & 29.6 \\
\hline N (h/day) & 5.0 & 12.0 & 12.0 & 120 & 12.0 & 12.0 & 12.0 \\
\hline HR (\%) & 68.9 & 72.4 & 59.0 & 650 & 63.0 & 70.8 & 66.0 \\
\hline n (h/month) & 238.3 & 213.5 & 229.2 & 2048 & 265.0 & 242.2 & 223.5 \\
\hline Rainfall (P, mm/year) & 449.7 & 468.1 & 251.8 & 628.3 & 190.1 & 634.6 & 328.1 \\
\hline
\end{tabular}

the country, respectively (Figure 1). For Sousse and Sidi Bouzid, annual rainfall varied between $200 \mathrm{~mm}$ and 300 $\mathrm{mm}$; all of them are located in the Centre of Tunisia. For Tunis and Nabeul, annual precipitations ranged between $400 \mathrm{~mm}$ and $500 \mathrm{~mm}$. The driest month is July and the wettest is January.

Monthly average rainfall amounts (mm) recorded between 1901 and 2000 and their ecartypes are presented in Figure 3 for the different cities. Largest variations between years were recorded during the rainiest months, i.e. December-February and September-November following the site. Lower variations between averge values were recorded during the summer months for all sites.

\subsubsection{Climatic Characterization of the Studied Cities}

The UNEP aridity index, which is adopted by the FAO and used worldwide, consists of the ratio of mean annual precipitation (P) to mean annual potential evapotranspiration $\mathrm{ET}_{0}$ computed with the Thornthwaite method [35] [86] [98]. Values are presented in Table 4 to climatically characterize the different cities on the basis of the following classification: Hyper-arid: 0 - 0.08, Arid: 0.08 - 0.2, Semi-arid: 0.2 - 0.5, Dry sub-humid: 0.5 - 0.65 , Moist sub humid: 0.65 - 1, Humid: 1 - 2.

Values of aridity index obtained herein points to:

1) Tunisia is not concerned with humid and sub-humid climates.

2) Arid and semi-arid climate dominate the central and southern landscape.

3) Although Bizerte, a coastal region, has a relatively high annual precipitation accompanied with cold winters, it is not considered as a sub-humid region. Its AI is close to that of Béja, a continental area of north Tunisia.

4) Arid climate refers to the areas of west (Sidi Bouzid) and south (Gabes) Tunisia, although Gabes is a coastal site.

The Aridity Index AI ranges between 0.11 and 0.43, making Tunisia mostly concerned with the arid (Gabes and Sidi Bouid) and semi-arid climates (other cites). This agrees partially with Kassas (2005) [39], for which 


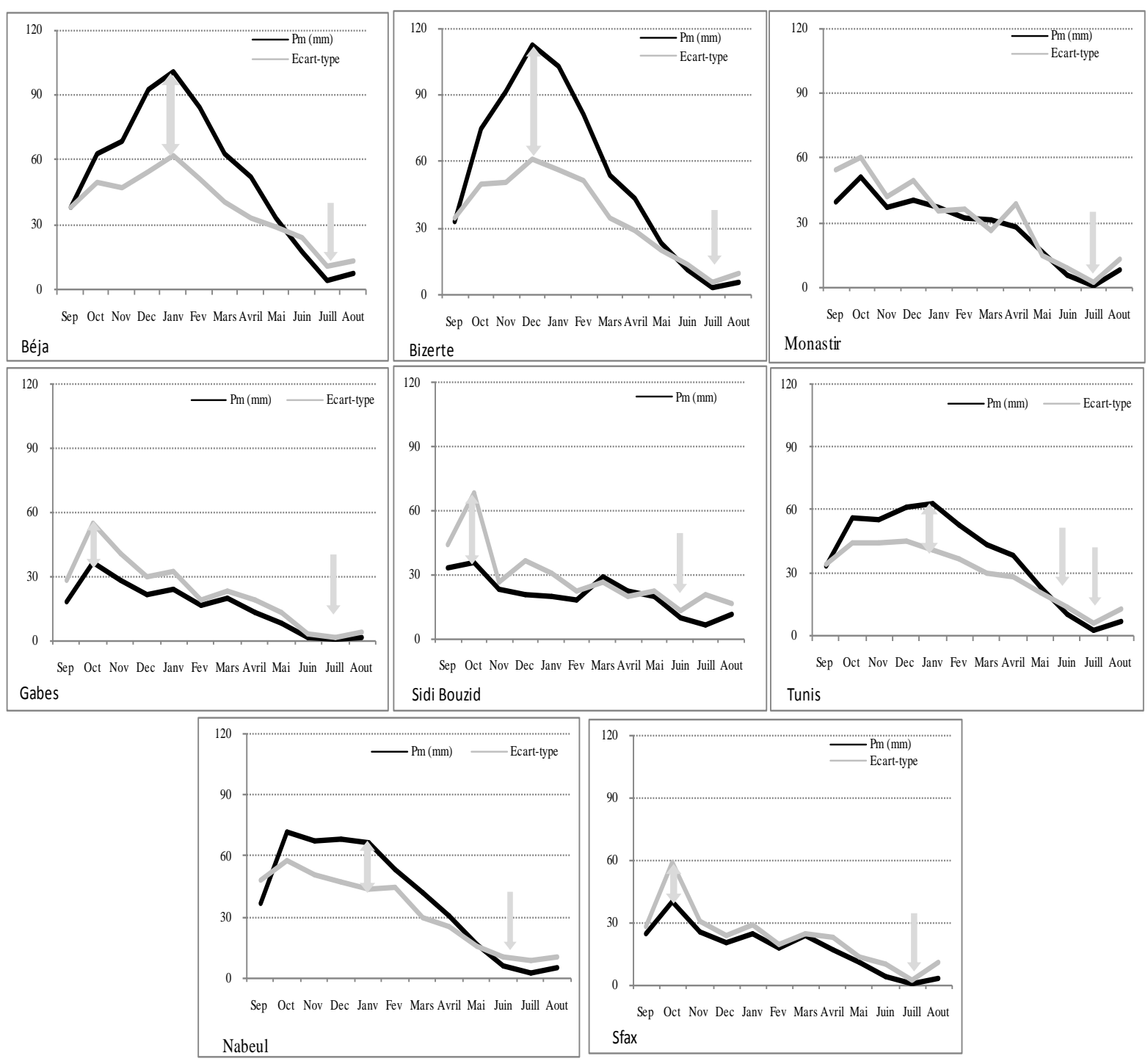

Figure 3. Monthly average rainfall amounts $(\mathrm{mm})$ recorded between years 1901 and 2000 and the corresponding ecartypes.

Table 4. Mean annual values of Thornth waite (TW) potential evapotranspiration (mm), precipitation (P, mm) and index of aridity (IA) calculated for the studied cites.

\begin{tabular}{ccccc}
\hline & $\mathrm{ET}_{0}$-TW (mm/year) & Rainfall (P, mm/year) & Index of aridity & Type of Climate \\
\hline Tunis & 1556.2 & 449.7 & 0.29 & Semi-arid \\
Béja & 1471.2 & 628.3 & 0.43 & Semi-arid \\
Nabeul & 1592.9 & 468.1 & 0.29 & Semi-arid \\
Monastir & 1679.5 & 328.1 & 0.20 & Semi-arid \\
Gabes & $\mathbf{1 7 6 2 . 0}$ & $\mathbf{1 9 0 . 1}$ & $\mathbf{0 . 1 1}$ & Arid \\
SB & $\mathbf{1 6 3 4 . 9}$ & $\mathbf{2 5 1 . 8}$ & $\mathbf{0 . 1 5}$ & Arid \\
Bizerte & 1494.4 & 634.6 & 0.42 & Semi-arid \\
\hline
\end{tabular}

"Thornthwaite (TW) classification based on the UNEP aridity index [86]. SB: Sidi Bouzid city. 
Tunisia is concerned with the semi-arid and arid climates in most areas and sub-humid in the extreme north of the country dominated by the mountains of Kroumirie, where the aridity index varies between 0.50 and 0.65 .

The climate sub-regions of Tunisia produced herein based on the spatial variability of the aridity index, are in relatively good agreement with the results of "The precipitation based regionalization studies for Tunisia" illustrating the main structure of the Tunisian climate [41] but different from others produced by using other index to climatically characterise the different regions of the country. According to the FAO classification based on the length of the growing period, Tunisia is found out of the dry lands because crops can grow over a long period, exceeding 120 days (4 months).

\subsubsection{Methods of $\mathrm{ET}_{0}$ Calculation}

Empirical formula used for $\mathrm{ET}_{0}$ calculation is detailed in a previous paper published by Habaieb and Masmoudi-Charfi (2003) [9], and summarized in Table 5. The parameterization scheme for $\mathrm{ET}_{0}\left(\mathrm{~L}\right.$ ground $\left.\mathrm{m}^{-2} \cdot \mathrm{d}^{-1}\right)$ estimation is reported in Table 6 . This schema adapted the PM-equation to be used with daily total net radiation $\left(\mathrm{R}_{\mathrm{n}}\right.$, MJ ground $\left.\mathrm{m}^{-2} \cdot \mathrm{d}^{-1}\right)$ and the corresponding daily averages for air temperature $\left(\mathrm{T}_{\text {mean }},{ }^{\circ} \mathrm{C}\right)$, wind speed $\left(\mathrm{U}_{2}, \mathrm{~m} \cdot \mathrm{s}^{-1}\right)$, vapor pressure deficit (VPD, $\mathrm{kPa}$ ) and conductances [8] [13] [99]. The equation uses standard records of solar radiation (sunshine), air temperature, humidity and wind speed. Currently the climate data to calculate $\mathrm{ET}_{0}-\mathrm{PM}$ are readily available from automated climate stations [1]. To ensure the integrity of computations, the weather measurements should be made at $2 \mathrm{~m}$ (or converted to that height, FAO 56) above an extensive surface of green grass, shading the ground and not short of water.

To appropriately compute the parameters of $\mathrm{ET}_{0}-\mathrm{PM}(\mathrm{mm} / \mathrm{day})$, the procedures proposed by Allen et al., (1998) [8] should be followed as indicated above. Gavilán et al., (2007) [20] reported that the methods proposed by Allen et al. (1998) [8] for estimating $\mathrm{R}_{\mathrm{n}}$ and $\mathrm{G}$ are appropriate for $\mathrm{ET}_{0}$ estimation for both daily and hourly

Table 5. Methods for $\mathrm{ET}_{0}$ calculation and corresponding formulas. Parameters used in the formula are defined in the list of abbreviations below.

\begin{tabular}{|c|c|c|}
\hline Method of $\mathrm{ET}_{0}$ computation & Climatic variable & Formula \\
\hline $\begin{array}{l}\text { Blaney-Criddle modified (1950) } \\
\text { by Doorenbos and Pruitt (1977) }\end{array}$ & $\mathrm{T}_{\text {average }}, \mathrm{n}, \mathrm{N}$ & $\mathrm{ET}_{\mathrm{o}}=\left(8+0.46 \mathrm{~T}_{\text {average }}\right) \times \mathrm{n} / \mathrm{N} / \mathrm{i}$ \\
\hline Hargreaves-Samani (1985) & $\begin{array}{l}\mathrm{T}_{\text {average, }}, \mathrm{R}_{\mathrm{a}}, \mathrm{T}_{\max } \\
\quad \mathrm{T}_{\min }, \mathrm{R}_{\mathrm{a}}\end{array}$ & $\begin{aligned} \text { Original: } \mathrm{ET}_{\mathrm{o}} & =0.0023 \mathrm{R}_{\mathrm{a}} \Delta \mathrm{T}^{0,5} \times\left(\mathrm{T}_{\text {average }}+17.8\right) \\
\text { Modified: } \mathrm{ET}_{\mathrm{o}} & =0.0035 \mathrm{R}_{\mathrm{a}} \Delta \mathrm{T}^{0,5} \times\left(\mathrm{T}_{\text {average }}+12.54\right)\end{aligned}$ \\
\hline Christiansen-Hargreaves (1969) & $\begin{array}{l}\mathrm{R}_{\mathrm{s}} \text { or } \mathrm{R}_{\mathrm{a}}, \mathrm{U}_{2}, \mathrm{~T}_{\text {average, }} \\
\mathrm{RH}_{\text {average }}, \mathrm{E}\end{array}$ & $\begin{array}{c}\text { Original: } \mathrm{ET}_{0}=0.492 \mathrm{R}_{\mathrm{s}} \times \mathrm{C}_{\mathrm{TT}} \times \mathrm{C}_{\mathrm{WT}} \times \mathrm{C}_{\mathrm{HT}} \\
\text { Modified: } \mathrm{ET}_{\mathrm{o}}=0.324 \mathrm{R}_{\mathrm{a}} \times \mathrm{C}_{\mathrm{TT}} \times \mathrm{C}_{\mathrm{WT}} \times \mathrm{C}_{\mathrm{HT}} \times \mathrm{C}_{\mathrm{ST}} \times \mathrm{C}_{\mathrm{R}}\end{array}$ \\
\hline $\begin{array}{l}\text { (1) Penman Original (1963) } \\
\text { (2) Penman Monteith (1998) }\end{array}$ & $\begin{array}{l}\mathrm{T}_{\text {average }}, \mathrm{e}_{\mathrm{o}}, \mathrm{U}_{2}, \mathrm{n}, \\
\mathrm{N}, \mathrm{R}_{\mathrm{a}}, \mathrm{RH}_{\text {average }}\end{array}$ & $\begin{array}{c}\mathrm{ET}_{0}=\left[\Delta /(\Delta+\gamma) \times\left(\mathrm{R}_{\mathrm{n}}+\mathrm{G}\right)\right]+\left[\gamma /(\Delta+\gamma) \times 15.36 \times\left(1+0,0062 \times \mathrm{U}_{2} \times\left(\mathrm{e}^{\mathrm{o}}-\mathrm{e}\right)\right)\right] \\
\mathrm{ET}_{0}=\frac{\left[0.408 \times \Delta \times\left(\mathrm{R}_{\mathrm{n}}-\mathrm{G}\right)\right]+\left[900 \times \gamma /(\mathrm{T}+273) \times\left(\mathrm{e}^{\mathrm{o}}-\mathrm{e}\right) \times \mathrm{U}_{2}\right]}{\Delta+\left[\gamma \times\left(1+0.34 \times \mathrm{U}_{2}\right)\right]}\end{array}$ \\
\hline Ivanov (1954) & $\begin{array}{c}\mathrm{T}_{\max }, \mathrm{T}_{\min }, \mathrm{T}_{\mathrm{m}}, \mathrm{e}_{\mathrm{o}} \\
\mathrm{RH}_{\text {average }}, \mathrm{RH}_{\max }, \mathrm{RH}_{\min }\end{array}$ & $\mathrm{ET}_{\mathrm{o}}=0.0018 \times(\mathrm{T}+25)^{2} \times\left(100-\mathrm{e} / \mathrm{e}^{\mathrm{o}} 100\right)$ \\
\hline Eagleman (1967) & $\begin{array}{l}\mathrm{T}_{\max }, \mathrm{T}_{\min }, \mathrm{T}_{\text {average, }}, \mathrm{e}_{\mathrm{o}} \\
\mathrm{RH}_{\text {average }}, \mathrm{RH}_{\max }, \mathrm{RH}_{\min }\end{array}$ & $\mathrm{ET}_{0}=0.035 \times \mathrm{e}^{\mathrm{o}} \times\left(100-\mathrm{RH}_{\text {average }}\right)^{0.5}$ \\
\hline Stephens and Stewart (1965) & $T_{\text {average }}, R_{a}, n, N$ & $\begin{aligned} \mathrm{ET}_{\mathrm{o}}= & \left(0.014 \mathrm{~T}_{\text {average }}-0.37\right) \times \mathrm{R}_{\mathrm{s}} / 1500 / 0.039 \\
& \text { with } \mathrm{R}_{\mathrm{s}}=(0.25+0.5 \mathrm{n} / \mathrm{N}) \times \mathrm{R}_{\mathrm{a}}\end{aligned}$ \\
\hline Turc (1961-1965). & $\begin{array}{l}\mathrm{T}_{\text {average, }} \mathrm{RH}_{\text {average, }} \\
\mathrm{R}_{\mathrm{a}}, \mathrm{n}, \mathrm{N}\end{array}$ & $\begin{array}{c}\mathrm{RH}>50 \%: \mathrm{ET}_{\mathrm{o}}=0.40\left(\mathrm{R}_{\mathrm{s}}+50\right) \mathrm{T}_{\text {average }} /\left(\mathrm{T}_{\text {average }}+15\right) \\
\mathrm{RH}<50 \%: \mathrm{ET}_{\mathrm{o}}=0.40\left(\mathrm{R}_{\mathrm{s}}+50\right) \mathrm{T}_{\text {average }} /\left(\mathrm{T}_{\text {average }}+15\right)\left(1+50-\mathrm{RH}_{\text {average }}\right) / 70 \\
\text { With } \mathrm{R}_{\mathrm{s}}=(0.25+0.5 \mathrm{n} / \mathrm{N}) \times \mathrm{R}_{\mathrm{a}}\end{array}$ \\
\hline
\end{tabular}

where: $\mathbf{T}_{\text {max }}$ : Maximum air temperature $\left({ }^{\circ} \mathrm{C}\right), \mathbf{T}_{\text {min }}$ : Minimum air temperature $\left({ }^{\circ} \mathrm{C}\right), \mathbf{T}_{\text {average: }}$ Mean daily air temperature $\left({ }^{\circ} \mathrm{C}\right)$, $\mathbf{T}_{\mathbf{m o n t h}}$ : Average monthly air temperature $\left({ }^{\circ} \mathrm{C}\right), \Delta \mathrm{T}$ : $\mathrm{T}_{\max }-\mathrm{T}_{\min }\left({ }^{\circ} \mathrm{C}\right), \Delta$ : Slope of the saturated vapor pressure curve $\left(\mathrm{KPa}{ }^{\circ} \mathrm{C}^{-1}\right), \gamma$ : Psychrometric constant $\left(\mathrm{KPa} \cdot{ }^{\circ} \mathrm{C}^{-1}\right)$, was set constant and equal to $0.066\left(\mathrm{KPa} /{ }^{\circ} \mathrm{C}\right), \mathbf{U}_{2}$ : Wind speed measured at $2 \mathrm{~m}$ height $(\mathrm{m} / \mathrm{s}), \mathbf{R H}_{\max }$ and $\mathbf{R} \mathbf{H}_{\min }$ : Maximum and minimum relative humidity of the air (\%), $\mathbf{e}_{\mathbf{s}}$ : Saturated vapor pressure (KPa), $\boldsymbol{e}_{\mathbf{s}}=0.5\left[e_{0}\left(T_{\max }\right)+e_{0}\left(T_{\min }\right)\right], \mathbf{e}^{\mathbf{0}}\left(T_{\max }\right)$ : Saturation vapor pressure (KPa) at $\mathrm{T}_{\max ,} \mathbf{e}^{\mathbf{0}}\left(\mathrm{Tmin}_{\mathrm{min}}\right)$ : Saturation vapor pressure $(\mathrm{KPa})$ at $\mathrm{T}_{\min }, \mathbf{e}_{\mathrm{a}}$ : Average value of vapor pressure or actual vapor pressure $(\mathrm{kPa}), \boldsymbol{e}_{\mathrm{a}}=\left[e_{\mathrm{o} T \max } \mathrm{RH}_{\min }+e_{\mathrm{o} T \min } \mathrm{H}_{\max }\right] / 200 . \boldsymbol{e}_{\mathbf{0}}-\boldsymbol{e}_{\mathrm{a}}: \mathrm{Saturated}$ vapor pressure deficit of the air (KPa), VPD, $\mathbf{R}_{\mathbf{a}}$ and $\mathbf{R}_{\mathbf{s}}$ : atmospheric and solar radiation $\left(\mathrm{Mj} / \mathrm{m}^{2} /\right.$ day). $\mathbf{R}_{\mathbf{n s}}$ : short radiations $\left(\mathrm{Mj} / \mathrm{m}^{2} /\right.$ day). $\mathbf{R}_{\mathbf{n l}}$ : long radiations $\left(\mathrm{Mj} / \mathrm{m}^{2} /\right.$ day). $\mathbf{N}$ : Maximum (Hours/day) sunshine duration, $\mathbf{n}$ : Actual sunshine duration (Hours $/ \mathrm{month}$ ), $\mathbf{n} / \mathbf{N}=\mathbf{p}$ : daylight hours monthly/annual daylight hours, $\mathbf{i}$ : number of days/month. $\mathbf{R}_{\mathbf{n}}$ : net radiation at the crop surface $\left(\mathrm{MJ} \cdot \mathrm{m}^{-2} \cdot \mathrm{day}^{-1}\right.$ ), $\mathrm{R}_{\mathrm{n}}$ is computed as the algebraic sum of the net short and long short radiations. K: Constant of Boltzman. $\mathbf{E T}_{\mathbf{0}}$ : Reference evapotranspiration (mm/day). G: Soil heat flux density $\left(\mathrm{MJ} \cdot \mathrm{m}^{-2} \cdot \mathrm{day}^{-1}\right)$, flux of heat into the soil, set equal to zero to represent the condition of an isolated tree. $\mathbf{G}_{\text {month }}$ : Monthly soil heat flux density (MJ $\left.\mathrm{m}^{-2}\right)$, PM: Penman-Monteith equation. 
Table 6. Daily $\mathrm{ET}_{0}(\mathrm{~mm})$ estimation procedure according to Penman-Monteith (PM) formula.

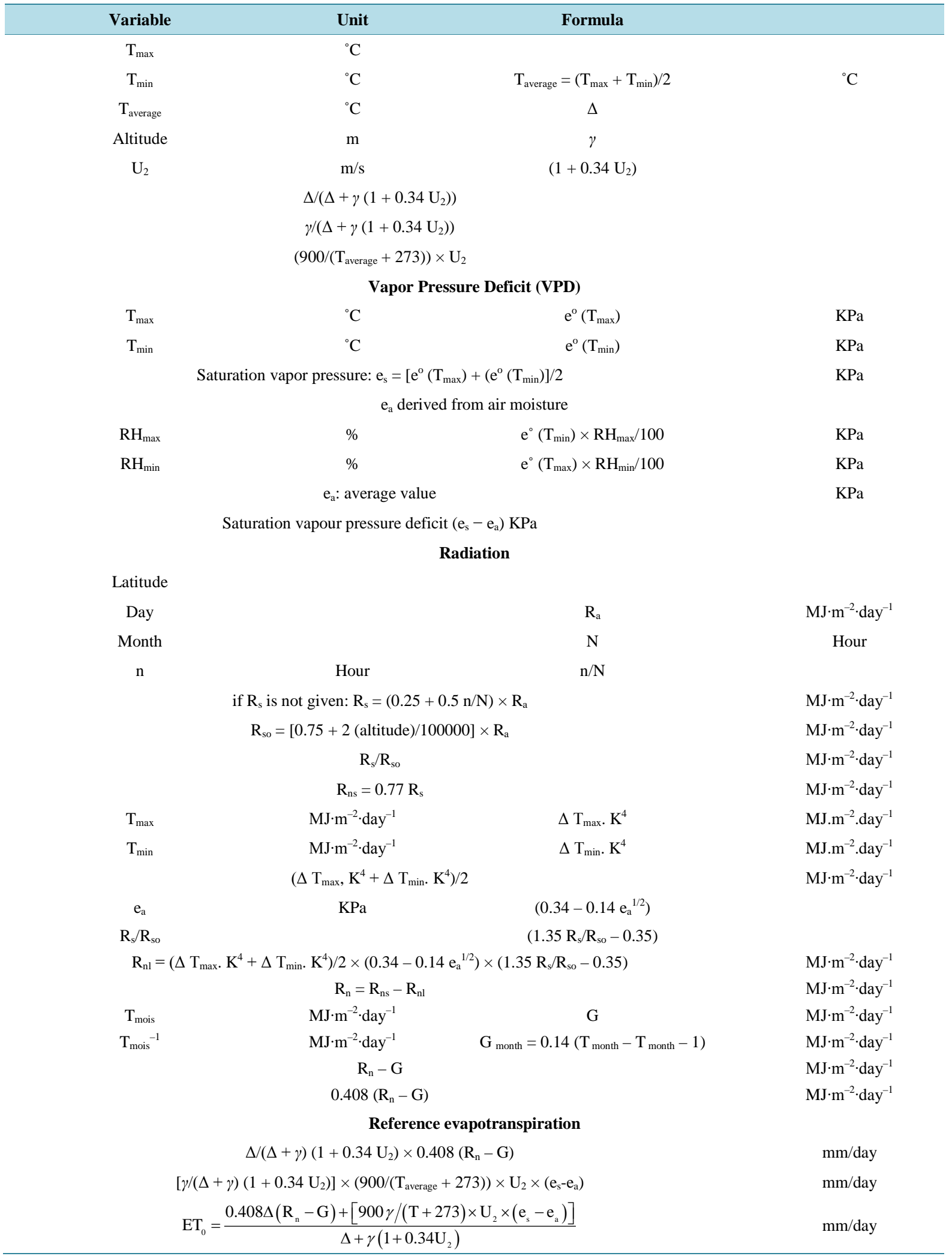

NB: Representative meanings of the variables indicated in Table 6 are defined in the previous page. 
time scales. Gong et al., (2006) [17] performed a sensitivity analysis of $\mathrm{ET}_{0}-\mathrm{PM}$ parameters and pointed to the very high influence of solar radiation and relative humidity in accurate estimation of $\mathrm{ET}_{0}$. Recently, Allen et al., (2011) [25] published a paper in which they present the factors governing measurement accuracy, while Popova et al., (2006) [30] validate the FAO methodology for computing $\mathrm{ET}_{0}$ with missing climatic data.

\subsubsection{Growing Periods, Kc Values, Crop Water Needs and Irrigation Amounts}

1) Growing periods

Olive is grown in the Mediterranean region over 270 days-long-period, beginning from March. Flower differenciation occurs from 15 February to 15 March while early fruit growth and pit hardening were observed from end of May to end of June. The ultimate fruit growth and oil synthesis were always observed beginning from 15 September. In order to adapt these stages to the available rainfall data, five growing periods were considered in this study, slightly different from the subdivisions made for the bisannual growing cycle [60] [63]:

1: March: shoot growth and flower development;

2: April-June: flowering and early fruit growth;

3: July and August: fruit development;

4: September-November: shoot growth, fruit enlargement, oil synthesis and olive maturation;

5: December-February: quiescence;

2) Crop coefficient $\left(K_{c}\right)$ values

Values of $K_{c}$ recommended by Allen et al., (1998) [8] for adult olive trees ranged between 0.5 and 0.7. For young trees, Lebourdelles (1977) [65] recommended the use of values of 0.3 for trees aged 1 year and 2 years, 0.4 for trees of 3 - 5 years and 0.5 - 0.7 for adult plants. Recently, Braham and Boussadia (2013) [96] found for Tunisia values ranging between 0.46 and 0.51 (Table 7) which were determined by using the sap flow technique of Granier (1985) [91], with an average value of 0.48 in April and 0.47 for May.

3) Crop water needs and irrigation amounts

Crop water needs were determined following the FAO method where $E T c=E T_{0} \times K_{c} \times K_{r}$. The coefficient $K_{r}$ was introduced to take into account the soil coverage.

Irrigation water requirements were determined by subtracting the rainfall $(\mathrm{P})$ that contributes to the evapotranspiration process from the estimated ETc.

\section{Results}

\subsection{Spatial Pattern of ET 0 -PM}

The range of annual $\mathrm{ET}_{0}$-PM varies from $1321.6 \mathrm{~mm}$ up to $1570.1 \mathrm{~mm}$ (Table 8), with maximum value observed in the arid area of Gabes (south-east of Tunisia) characterized by high temperature and radiation levels. Lowest annual $\mathrm{ET}_{0}$ is recorded at Béja, a continental area of north-western Tunisia. Inversely, the highest seasonal $\mathrm{ET}_{0}-\mathrm{PM}$ value is recorded in the continental area of Centre-western Tunisia (Sidi Bouzid), a mountainuous area situated at $314 \mathrm{~m}$ height, while the lowest value is observed at Bizerte, a coastal and windy town of North Tunisia.

Daily maximum values ranged between $6.5 \mathrm{~mm}$ (Bizerte) and $7.1 \mathrm{~mm}$ (Sidi Bouzid), while minimums were

Table 7. Values of $\mathrm{K}_{\mathrm{c}}$ obtained for olive trees cultivated in the Centre of Tunisia under adequate watering conditions [96].

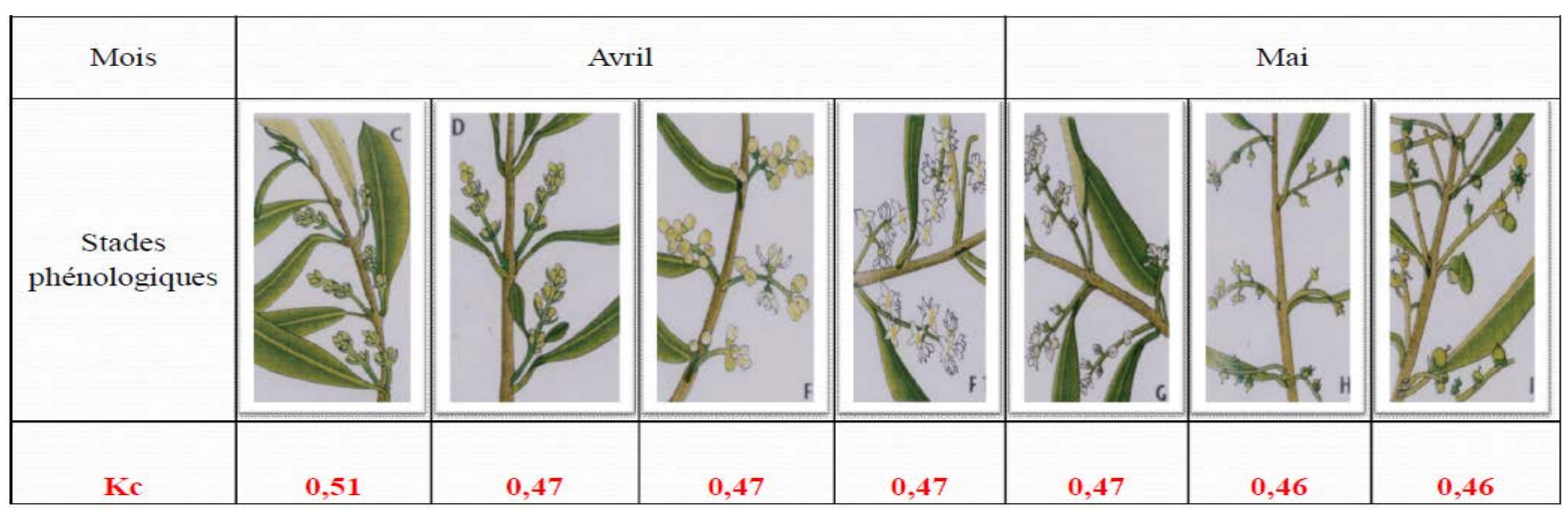


recorded in December and January and varied between $1.2 \mathrm{~mm}$ (Béja) and $2.2 \mathrm{~mm}$ (Sousse) (Table 9). Highest daily values of $\mathrm{ET}_{0}-\mathrm{PM}$ are those recorded for the arid regions of Gabes and Sidi Bouzid, while the lowest are observed for the East (Bizerte) and West (Béja) northern areas.

The spatial pattern of $\mathrm{ET}_{0}$ estimated using full datasets show a gradual increase of $\mathrm{ET}_{0}$ to peak in July (Figure 4). Average annual value is well correlated to the maximum and minimum daily estimates, providing a poly

Table 8. Annual and seasonal $\mathrm{ET}_{0}$-PM (mm).

\begin{tabular}{ccc}
\hline Site & $\mathrm{ET}_{0}-\mathrm{PM}(\mathrm{mm} / \mathrm{year})$ & $\mathrm{ET}_{0}-\mathrm{PM}(\mathrm{mm} /$ season $)$ \\
\hline Tunis & 1423.6 & 896.5 \\
Nabeul & 1484.7 & 871.1 \\
SB & 1485.0 & 907.1 \\
Sousse & 1527.1 & 879.8 \\
Bizerte & 1334.1 & 839.6 \\
Gabes & 1570.1 & 894.0 \\
Béja & 1321.6 & 885.7 \\
\hline
\end{tabular}

Table 9. Average daily estimates of $\mathrm{ET}_{0}$ ( $\mathrm{mm} /$ day) computed with the PM-method.

\begin{tabular}{ccccccccccccc}
\hline PM (mm/day) & JAN & FEB & MAR & AVP & MAY & JUN & JULY & AUG & SEP & OCT & NOV & DEC \\
\hline Tunis & 1.65 & 2.13 & 2.76 & 3.59 & 4.86 & 6.08 & 6.99 & 6.49 & 4.85 & 3.30 & 2.27 & 1.70 \\
Sidi Bouzid & 1.91 & 2.51 & 3.15 & 4.02 & 5.06 & 6.18 & 7.10 & 6.38 & 4.91 & 3.34 & 2.34 & 1.81 \\
Sousse & 2.18 & 2.72 & 3.35 & 4.02 & 4.87 & 5.75 & 6.64 & 6.24 & 5.23 & 4.01 & 2.94 & 2.16 \\
Nabeul & 2.05 & 2.65 & 3.25 & 3.96 & 4.62 & 5.90 & 6.63 & 6.19 & 5.12 & 3.54 & 2.72 & 2.10 \\
Bizerte & 1.60 & 1.98 & 2.60 & 3.38 & 4.38 & 5.65 & 6.54 & 6.17 & 4.67 & 3.10 & 2.05 & 1.62 \\
Béja & 1.19 & 1.78 & 2.32 & 3.28 & 4.59 & 5.93 & 7.01 & 6.56 & 4.83 & 2.94 & 1.72 & 1.16 \\
Gabes & 2.37 & 2.89 & 3.50 & 4.31 & 5.11 & 5.93 & 6.55 & 6.27 & 5.35 & 4.05 & 2.98 & 2.21 \\
Max & 2.37 & 2.89 & 3.50 & 4.31 & 5.11 & 6.18 & 7.10 & 6.56 & 5.35 & 4.05 & 2.98 & 2.21 \\
Min & 1.19 & 1.78 & 2.32 & 3.28 & 4.38 & 5.65 & 6.54 & 6.17 & 4.67 & 2.94 & 1.72 & 1.16
\end{tabular}
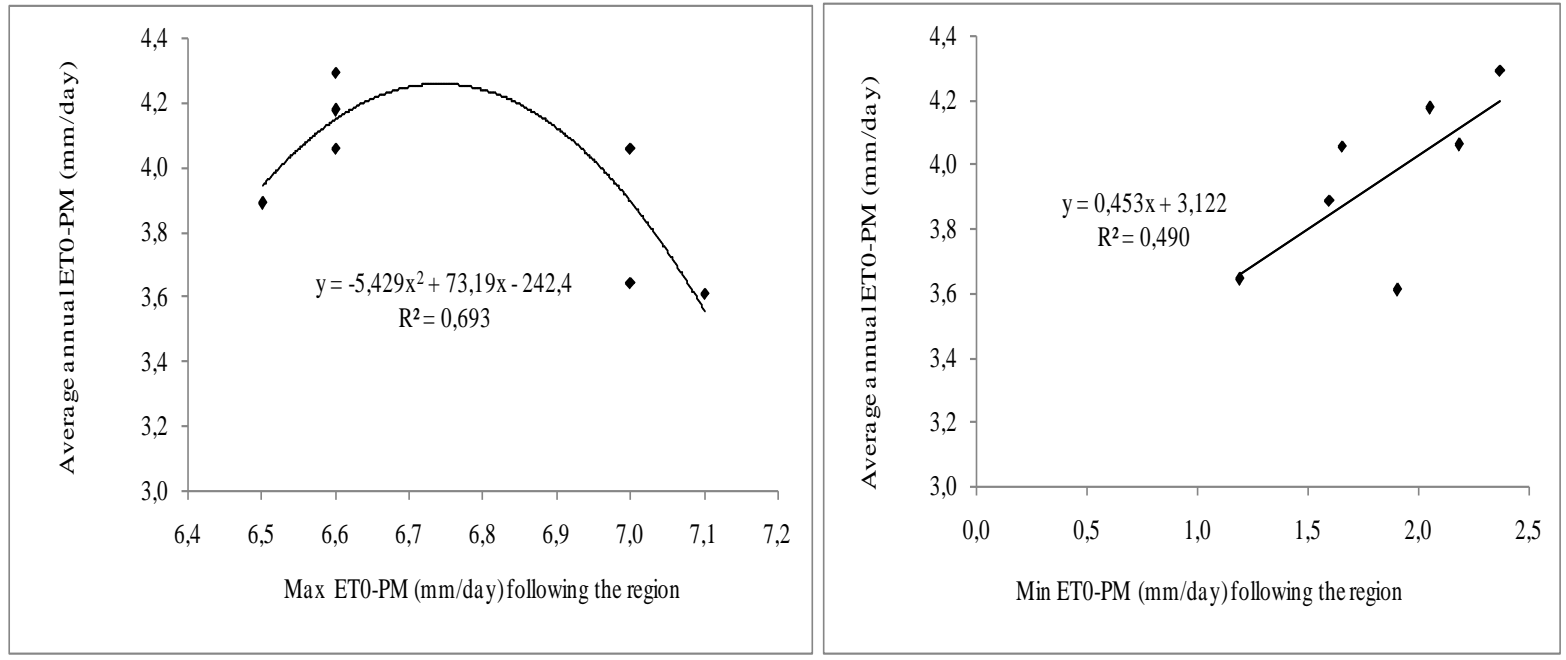

Figure 4. Statistic relationships between the average annual $\mathrm{ET}_{0}-\mathrm{PM}(\mathrm{mm} / \mathrm{day})$ and the maximum and minimum daily estimates computed for the studied cities $(p=0.05)$. 
nomial curve in the first case $(r=0.83)$ and a linear positive correlation in the second case $(r=0.70)$. For regions where maximum $\mathrm{ET}_{0}-\mathrm{PM}$ (July) exceeds $6.6 \mathrm{~mm} /$ day (Tunis $=7 \mathrm{~mm}$; $\mathrm{SB}=7.1 \mathrm{~mm}$; Béja $=7.0 \mathrm{~mm}$ ), minimum values recorded in winter are lower, ranging between 1.2 and $1.9 \mathrm{~mm} / \mathrm{day}$ (Tunis $=1.7 \mathrm{~mm}$; Sidi Bouzid $=1.9 \mathrm{~mm}$; Béja $=1.2 \mathrm{~mm}$ ). For the case of Sousse, Nabeul and Gabes, all coastal areas, maximum ET $\mathrm{E}_{0}-\mathrm{PM}$ is $6.6 \mathrm{~mm}$ (July) while minimum values reached $2.2 \mathrm{~mm} ; 2.1 \mathrm{~mm}$ and $2.4 \mathrm{~mm}$ respectively. This is the result of the proximity of the sea which temperates the climate of the surrounding areas by decreasing the summer $\mathrm{ET}_{0}-\mathrm{PM}$ values and increasing the winter ones.

Seasonal values computed following the growing periods show lower and higher estimates for west Tunisia (Beja) during winter-early spring and summer periods, respectively (Figure 5). $\mathrm{ET}_{0}-\mathrm{PM}$ varies between $50 \mathrm{~mm}$ and $70 \mathrm{~mm}$ during period 5 (December-February) and reaches $100 \mathrm{~mm}$ (Gabes) in March (period 1). Estimates of $\mathrm{ET}_{0}$ ranged between $100 \mathrm{~mm}$ and $180 \mathrm{~mm}$ during period 2 (April-June). Lower values recorded during period 1 and 2 are those of Béja and Bizerte. Maximums are recorded in July, exceeding $200 \mathrm{~mm} / \mathrm{month}$ for all stations. Those recorded in August are slightly lower. During period 5 (September-November), $\mathrm{ET}_{0}-\mathrm{PM}$ ranges between $50 \mathrm{~mm}$ and $150 \mathrm{~mm}$.

The spatial distribution of $\mathrm{ET}_{0}$ didn't follow the typical variability stipulating their increase southward and westward due to the decrease in latitude and the increase of altitude, respectively as reported by Razieia and Pereira (2013) [86]. However the spatial pattern of $\mathrm{ET}_{0}$ computed at Bizerte resemble to that of Tunis, both located in North of Tunisia. Highest daily values were recorded for the arid regions of Gabes and Sidi Bouzid, while the lowest are observed for both the East (Bizerte) and West (Béja) northern areas. During summer months, Tunis and Béja present the highest values although they are situated at different latitudes and altitudes.

\section{2. $\mathrm{ET}_{0}$ Estimates Following the Empirical Formulas Compared to PM-Computations}

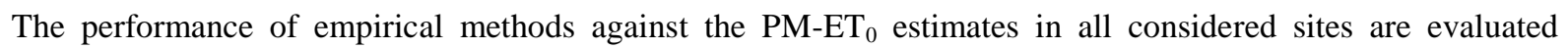
graphically (Figure 6) and statistically (Table 11). Significant positive correlations are observed with $\mathrm{r}$ values exceeding 0.88 .

To assess the performance of these methods with respect to $\mathrm{ET}_{0}-\mathrm{PM}$, relative to all values for each station, the $r$ values were determined. When the coefficient of correlation $r$ is close to 1.0, most of the variation of the observed values can be explained by the linear model.

Variations between values are due to site characteristics and the formula used for $\mathrm{ET}_{0}$ estimation. Values of $\mathrm{r}$ ranged between 0.880 and 0.999 (Table 10). The Eagleman method gave the highest values out of the range of those given by all the other formulas, while the lowest were provided by the HS formula. The lowest $r$ coefficients were obtained for the cities of Sousse $(r=0.888)$ and Gabes $(r=0.885)$ when $\mathrm{ET}_{0}$ is estimated by using the PO and Ivanov methods, respectively. These statistical coefficients are site specific even for the same species (e.g., olives) and the function for one orchard could not be used for the other.

Results show that when the series of climatic data is incomplete, $\mathrm{ET}_{0}$ can be estimated by another empirical method depending on the available climatic variables. Formula that gives values of $\mathrm{ET}_{0}$ approximating $\mathrm{ET}_{0}-\mathrm{PM}-$ the universal reference estimating $\mathrm{ET}_{0}$ method for each site are reported in Table 7 and Table 8. Results show that methods of ST and SW are suitable for all stations. For Tunis, Nabeul and Sidi Bouzid, the method of Chr.

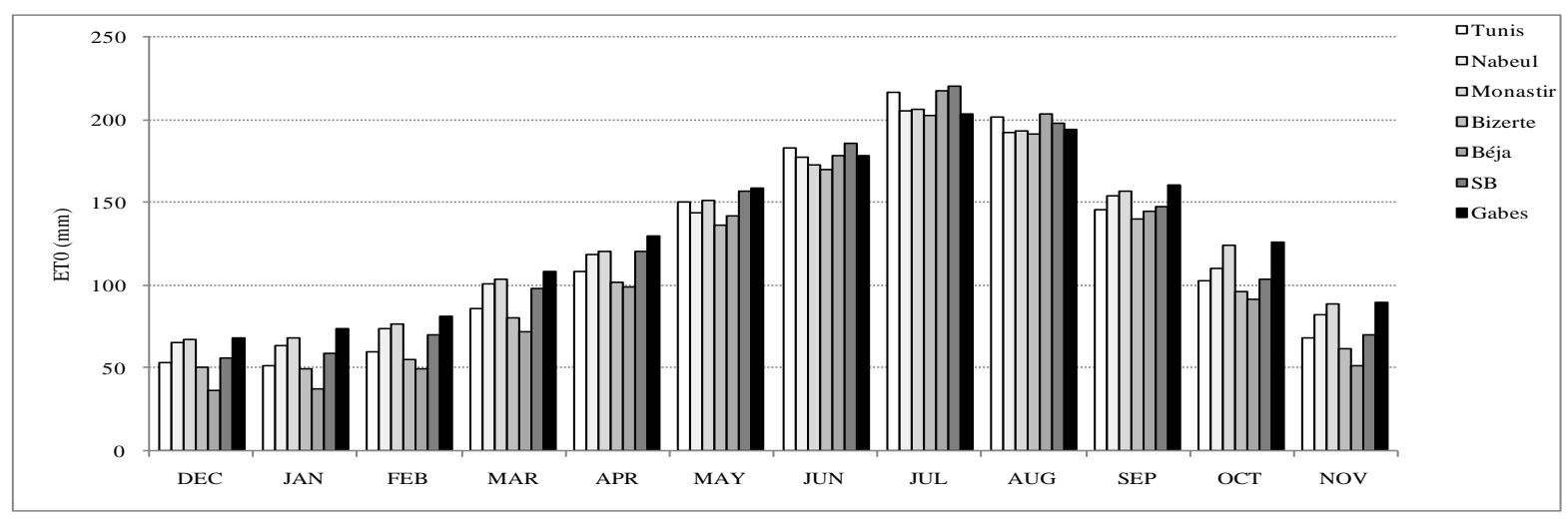

Figure 5. Values of $\mathrm{ET}_{0}$ following the growing period and site of olive cultivation. 


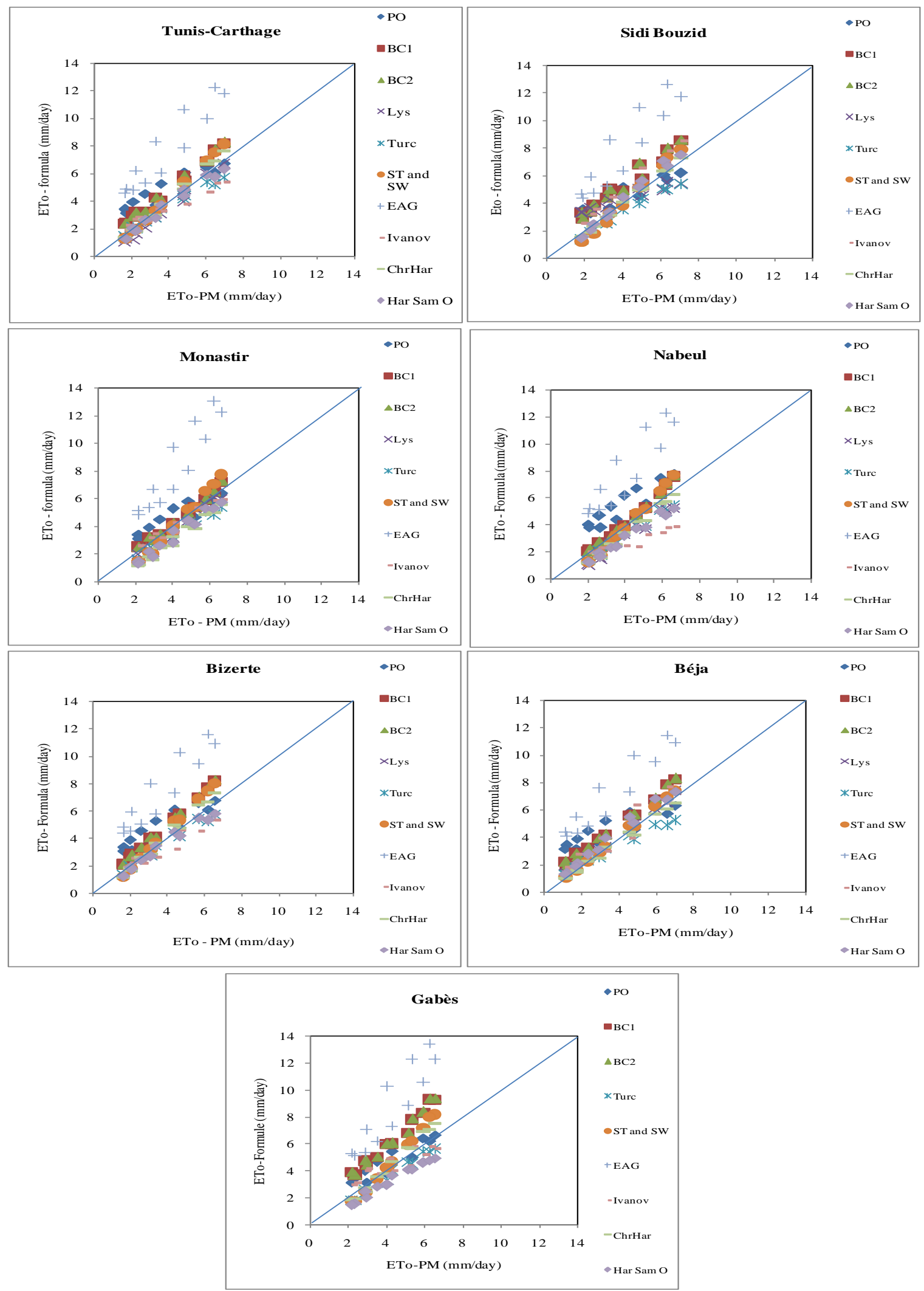

Figure 6. Relationship between $\mathrm{ET}_{0}-\mathrm{PM}$ estimates and values of $\mathrm{ET}_{0}$ determined by different calculation methods $(\mathrm{mm} /$ day) for all studied sites $(\mathrm{p}=0.05)$. 
Table 10. Coefficients of correlation obtained for the different sites. $\mathrm{ET}_{0}$ estimated by several methods are compared to $\mathrm{ET}_{0}$-PM computations.

\begin{tabular}{cccccccccc}
\hline & PO & BC1 & BC2 & Turc & ST and SW & EAG & Ivanov & Chr Harg & Harg Sam \\
\hline Bizerte & 0.918 & 0.999 & 0.999 & 0.988 & 0.999 & 0.935 & 0.961 & 0.996 & 0.988 \\
Tunis & 0.926 & 0.994 & 0.994 & 0.992 & 0.999 & 0.939 & 0.962 & 0.997 & 0.990 \\
Béja & 0.900 & 0.997 & 0.997 & 0.990 & 0.999 & 0.949 & 0.952 & 0.996 & 0.992 \\
Gabes & 0.926 & 0.991 & 0.991 & 0.979 & 0.995 & 0.909 & 0.885 & 0.991 & 0.970 \\
Sousse & 0.888 & 0.993 & 0.993 & 0.981 & 0.996 & 0.932 & 0.958 & 0.989 & 0.983 \\
Nabeul & 0.927 & 0.993 & 0.993 & 0.990 & 0.997 & 0.907 & 0.950 & 0.995 & 0.990 \\
Sidi Bouzid & 0.921 & 0.980 & 0.980 & 0.993 & 0.997 & 0.922 & 0.973 & 0.999 & 0.995 \\
\hline
\end{tabular}

Harg. gave valuable results as well as that of BC for Bizerte, Béja, Gabes and Sousse, which are coastal regions.

However, the method of calculating the best $\mathrm{ET}_{0}$ values changes following the growing period. The formula that gives values of $\mathrm{ET}_{0}$ approximating $\mathrm{ET}_{0}$-PM for each city (Table 11 and Table 12) indicates:

For Nabeul and Monastir, the BC formula is valuable for most periods of growth.

For Sidi Bouzid, the HS is valuable for stages 1, 4 and 5 and that of Chr. Harg. for stages 2 and 3 and the overall growing cycle.

For Bizerte, the method of ST and SW gives values of $\mathrm{ET}_{0}$ approximating those of $\mathrm{ET}_{0}$-PM for the overall growing cycle and stages 1 and 4 .

The regions of Tunis, Sousse, Nabeul, Bizerte and Gabes are localized on the coast but a different 'response' is observed for a given stage of development.

For Bizerte, Tunis, Béja, Gabes, Sousse and Nabeul, the ST and SW method is noted as the best one for the overall cycle and for stages 4 for the first stations and 2 for Nabeul.

Linearly with $\mathrm{ET}_{0}-\mathrm{PM}$, the Ivanov method appropriately predicts $\mathrm{ET}_{0}$ in all sites of Tunisia situated in the North and costal areas as it gives the lowest relative variation of $\mathrm{ET}_{0}$. Table 12 suggests that the Ivanov method particularly performs well with the cities of Tunis, Nabeul and Bizerte characterized by semi arid climate, having annual rainfall of up to $450 \mathrm{~mm}$. But when considering the lowest seasonal climatic deficit (P-ETc), it appears that the Turc formula is most appropriate for Tunis but also for Sousse, a coastal area of centre Tunisia. The Turc method also performs reasonably well in western areas, i.e. at Sidi Bouzid (arid climate) and Béja (semi-arid climate). Low climatic deficits were recorded at seasonal scale at both sites. For Gabes, the most appropriate method is that of Harg. Sam.

It appears from these results that the most appropriate method for $\mathrm{ET}_{0}$ estimation at annual scale may be different from that providing the best value of $\mathrm{ET}_{0}$ when considering the growing periods. Though, it is important to well define the researched objective. Indeed, the formula of Turc although it gave the best response for Sousse when estimating the annual $\mathrm{ET}_{0}$ value, it wasn't the appropriate method when considering the growing periods. Adversely, although the method of BC is suitable for periods 1, 2, 4 and 5 at Sousse, the appropriate method for the overall cycle is that of Turc. This formula (Turc) is appropriate for Tunis, Sidi Bouzid, Sousse and Béja at annual scale despite of their appartenance to different climatic regions, while the method of Ivanov is quite valuable for Bizerte and Nabeul. At seasonal scale, the formula of BC is appropriate for stages 1,4 and 5 for Tunis, Nabeul and Monsatir. That of Turc is valuable for stages 1 and 5 at Béja.

\subsection{Crop Water Needs}

Average ETC values are calculated for each site following age and the growing period (Table 13). The annual course of ETc computed by using $\mathrm{ET}_{0}-\mathrm{PM}$ values shows minimum estimates close to 300 mm per year for young trees and maximum values ranging between $800 \mathrm{~mm}$ and $1000 \mathrm{~mm}$ for the older ones. Highest annual values of ETC are those recorded for Gabes, ranging between $335 \mathrm{~mm}$ and $894 \mathrm{~mm}$ depending on age. Minimum yearly values are those of Béja varying from $282 \mathrm{~mm}$ and $752 \mathrm{~mm}$, due to $\mathrm{ET}_{0}$ variations.

Water requirements (Table 13) increases during the first period of growth (March) from $15 \mathrm{~mm}$ to $40 \mathrm{~mm}$ for 
Table 11. Appropriate methods for $\mathrm{ET}_{0}$ calculation following the region and the growing period. Costal and northern cities.

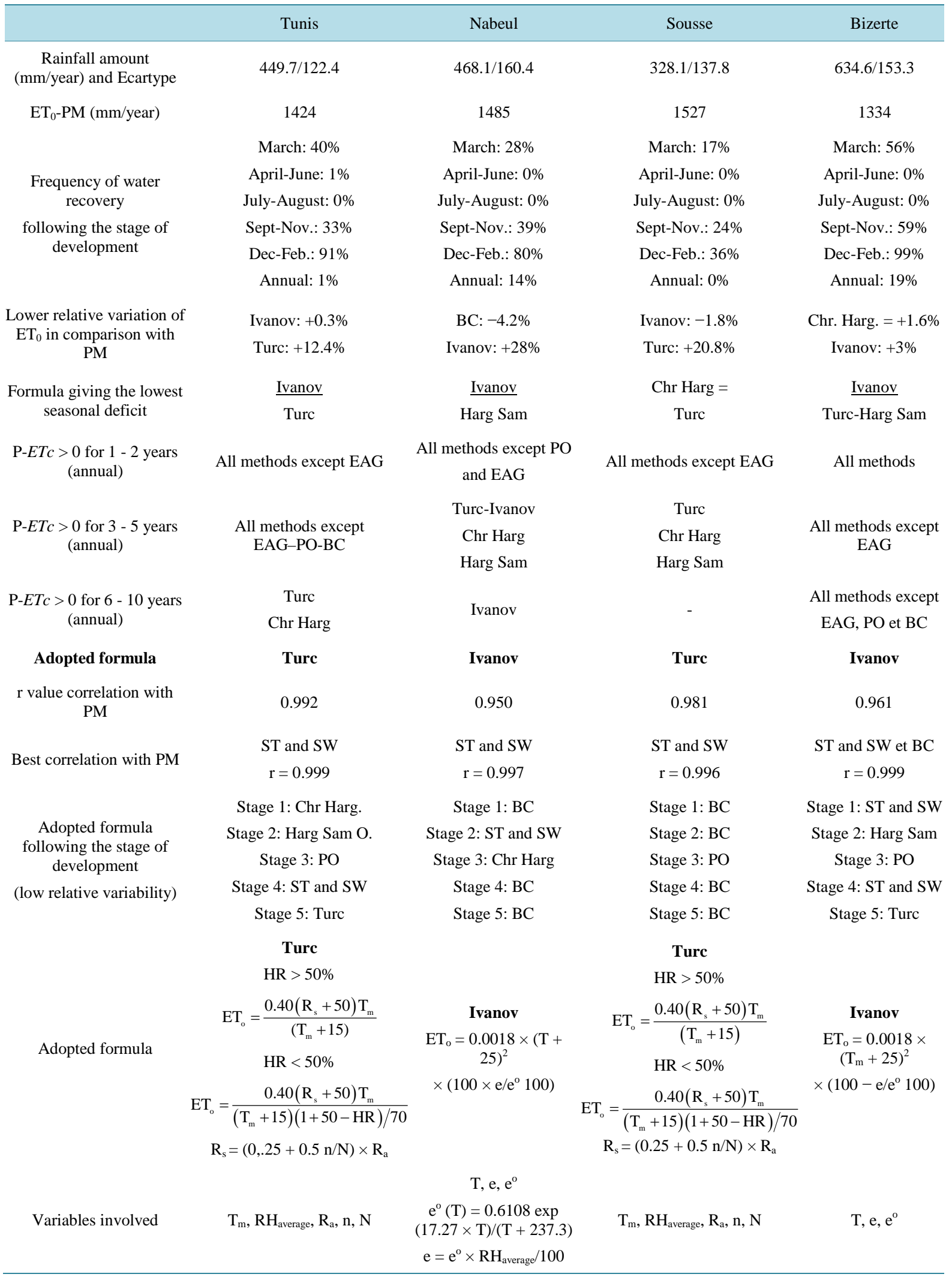


Table 12. Appropriate methods for $\mathrm{ET}_{0}$ calculation following the region and the growing period. Continental and southern cities.

\begin{tabular}{|c|c|c|c|}
\hline & Sidi Bouzid & Gabes & Béja \\
\hline $\begin{array}{l}\text { Rainfall amount (mm/year) and } \\
\text { Ecartype }\end{array}$ & 251.8/121.4 & 190.1/98.7 & $628.9 / 154.8$ \\
\hline $\mathrm{ET}_{0}-\mathrm{PM}(\mathrm{mm} /$ year$)$ & 1485 & 1570 & 1322 \\
\hline \multirow{6}{*}{$\begin{array}{c}\text { Frequency of water recovery } \\
\text { following the stage of develop- } \\
\text { ment }\end{array}$} & March: $17 \%$ & March: 5\% & March: 73\% \\
\hline & April-June: 0\% & April-June: 0\% & April-June: $4 \%$ \\
\hline & July-August: $0 \%$ & July-August: $0 \%$ & July-August: $0 \%$ \\
\hline & Sept-Nov: 8\% & Sept-Nov: 4\% & Sept-Nov: 48\% \\
\hline & Dec-Feb: 5\% & Dec-Feb: $14 \%$ & Dec-Feb: 99\% \\
\hline & Annual: 7\% & Annual: 7\% & Annual: $18 \%$ \\
\hline \multirow{2}{*}{$\begin{array}{l}\text { Lower relative variation of } \mathrm{ET}_{0} \text { in } \\
\text { comparaison with PM }\end{array}$} & Harg Sam O.: +12.5\% & Chr Harg: $-1.4 \%$ & ST and SW: $+2.4 \%$ \\
\hline & Turc: $+20.4 \%$ & Harg. Sam: +23.9\% & Turc: $+9.3 \%$ \\
\hline Formula giving the lowest & \multirow{2}{*}{ Turc } & Harg Sam & Turc \\
\hline seasonal deficit & & Turc & Chr Harg \\
\hline $\begin{array}{l}\mathrm{P}-E T C>0,1-2 \text { years } \\
\quad \text { (annual) }\end{array}$ & - & - & All formula \\
\hline $\mathrm{P}-E T C>0,3-5$ years (annual) & - & - & All formula except EAG \\
\hline \multirow{2}{*}{$\mathrm{P}-E T C>0,6-10$ years (annual) } & \multirow{2}{*}{-} & \multirow{2}{*}{-} & All formula except \\
\hline & & & EAG, PO et BC \\
\hline Adopted formula & Turc & Harg Sam & Turc \\
\hline r value correlation with PM & 0.993 & 0.970 & 0.990 \\
\hline \multirow{2}{*}{ Meilleure corrélation avec PM } & Chr Harg & ST and SW & ST and SW \\
\hline & $r=0.999$ & $r=0.995$ & $r=0.999$ \\
\hline \multirow{5}{*}{$\begin{array}{l}\text { Adopted formula following the } \\
\text { stage of development } \\
\text { (low relative variability) }\end{array}$} & Stage 1: Harg Sam & Stage 1: Chr Harg & Stage 1: Turc \\
\hline & Stage 2: Chr Harg & Stage 2: Turc & Stage 2: Chr Harg \\
\hline & Stage 3: Chr Harg & Stage 3: PO & Stage 3: Harg Sam \\
\hline & Stage 4: Harg Sam & Stage 4: ST and SW & Stage 4: ST and SW \\
\hline & Stage 5: Harg Sam & Stage 5: Chr Harg & Stage 5: Turc \\
\hline \multirow{6}{*}{ Adopted formula } & Turc & \multirow{3}{*}{$\begin{array}{c}\text { Hargreaves-Samani } \\
\text { Original: } \mathrm{ET}_{0}=0.0023 \mathrm{R}_{\mathrm{a}} \Delta \mathrm{T} \\
{ }_{0,5} \mathrm{x}\left(\mathrm{T}_{\mathrm{m}}+17.8\right)\end{array}$} & Turc \\
\hline & $\mathrm{HR}>50 \%$ & & $\mathrm{HR}>50 \%$ \\
\hline & $\mathrm{ET}_{\mathrm{o}}=\frac{0.40\left(\mathrm{R}_{\mathrm{s}}+50\right) \mathrm{T}_{\mathrm{m}}}{\left(\mathrm{T}_{\mathrm{m}}+15\right)}$ & & $\mathrm{ET}_{\mathrm{o}}=\frac{0.40\left(\mathrm{R}_{\mathrm{s}}+50\right) \mathrm{T}_{\mathrm{m}}}{\left(\mathrm{T}_{\mathrm{m}}+15\right)}$ \\
\hline & HR < $50 \%$ : & \multirow{3}{*}{$\begin{array}{c}\text { Modified: } \\
\mathrm{ET}_{\mathrm{o}}=0.0035 \mathrm{R}_{\mathrm{a}} \Delta \mathrm{T}^{0,5} \\
\mathrm{x}\left(\mathrm{T}_{\mathrm{m}}+12.54\right)\end{array}$} & HR < $50 \%$ : \\
\hline & $\mathrm{ET}_{\mathrm{o}}=\frac{0.40\left(\mathrm{R}_{\mathrm{s}}+50\right) \mathrm{T}_{\mathrm{m}}}{\left(\mathrm{T}_{\mathrm{m}}+15\right)(1+50-\mathrm{HR}) / 70}$ & & $\mathrm{ET}_{\mathrm{o}}=\frac{0.40\left(\mathrm{R}_{\mathrm{s}}+50\right) \mathrm{T}_{\mathrm{m}}}{\left(\mathrm{T}_{\mathrm{m}}+15\right)(1+50-\mathrm{HR}) / 70}$ \\
\hline & $\mathrm{R}_{\mathrm{s}}=(0.25+0.5 \mathrm{n} / \mathrm{N}) \times \mathrm{R}_{\mathrm{a}}$ & & $\mathrm{R}_{\mathrm{s}}=(0.25+0.5 \mathrm{n} / \mathrm{N}) \times \mathrm{R}_{\mathrm{a}}$ \\
\hline Variables involved & $\mathrm{T}_{\mathrm{m}}, \mathrm{RH}_{\text {average }}, \mathrm{R}_{\mathrm{a}}, \mathrm{n}, \mathrm{N}$ & $\mathrm{T}_{\mathrm{m}}, \mathrm{R}_{\mathrm{a}}, \mathrm{T}_{\max }, \mathrm{T}_{\min }, \mathrm{R}_{\mathrm{a}}$ & $\mathrm{T}_{\mathrm{m}}, \mathrm{RH}_{\text {average }}, \mathrm{R}_{\mathrm{a}}, \mathrm{n}, \mathrm{N}$ \\
\hline
\end{tabular}

Béja following age, from $21 \mathrm{~mm}$ to $55 \mathrm{~mm}$ for Sidi Bouzid, from $18 \mathrm{~mm}$ to $48 \mathrm{~mm}$ for Tunis, from $21 \mathrm{~mm}$ to 46 $\mathrm{mm}$ for Nabeul, from $22 \mathrm{~mm}$ to $52 \mathrm{~mm}$ for Sousse, from $17 \mathrm{~mm}$ to $45 \mathrm{~mm}$ for Bizerte and from $23 \mathrm{~mm}$ and $61 \mathrm{~mm}$ for Gabes. For the other periods (April to November, 2 to 4), water needs increased consistently with values ranging between $87 \mathrm{~mm}$ and $254 \mathrm{~mm}$ for the coastal areas and from $90 \mathrm{~mm}$ to $266 \mathrm{~mm}$ for the continental locations. Minimum ETC values were recorded when the formulas of Turc, Chr. Harg, Harg.Sam and Ivanov are used. 
Table 13. Water requirements of olive trees $(E T c, \mathrm{~mm})$ following age, site, growing periods and methods of $\mathrm{ET}_{0}$ computation.

\begin{tabular}{|c|c|c|c|c|c|c|c|c|c|c|c|c|c|c|}
\hline Bizerte & 1 & 2 & 3 & 4 & 5 & $\mathrm{PM}$ & $\mathrm{PO}$ & $\mathrm{BC}$ & Turc & STand SW & EAG & Ivanov & Chr-Harg & Harg-Sam O. \\
\hline 1 - 2 years & 17 & 87 & 83 & 64 & 34 & 285 & 374 & 366 & 262 & 315 & 575 & 259 & 295 & 261 \\
\hline 3 - 5 years & 23 & 116 & 110 & 85 & 45 & 380 & 499 & 488 & 350 & 419 & 766 & 346 & 394 & 347 \\
\hline 6 - 10 years & 30 & 156 & 148 & 114 & 60 & 508 & 668 & 653 & 468 & 562 & 1026 & 463 & 527 & 465 \\
\hline$>10$ years & 45 & 233 & 221 & 170 & 90 & 759 & 997 & 975 & 699 & 839 & 1532 & 691 & 787 & 695 \\
\hline Sousse & 1 & 2 & 3 & 4 & 5 & $\mathrm{PM}$ & $\mathrm{PO}$ & $\mathrm{BC}$ & Turc & STand SW & EAG & Ivanov & Chr-Harg & Harg-Sam O. \\
\hline 1 - 2 years & 22 & 95 & 84 & 79 & 46 & 326 & 363 & 349 & 262 & 322 & 647 & 320 & 243 & 265 \\
\hline 3 - 5 years & 29 & 127 & 112 & 106 & 61 & 435 & 483 & 465 & 349 & 429 & 863 & 426 & 324 & 353 \\
\hline 6 - 10 years & 39 & 170 & 150 & 142 & 82 & 582 & 648 & 623 & 467 & 574 & 1155 & 571 & 434 & 473 \\
\hline$>10$ years & 58 & 254 & 224 & 211 & 122 & 870 & 967 & 931 & 698 & 858 & 1725 & 852 & 649 & 707 \\
\hline Béja & 1 & 2 & 3 & 4 & 5 & $\mathrm{PM}$ & $\mathrm{PO}$ & $\mathrm{BC}$ & Turc & STand SW & EAG & Ivanov & Chr-Harg & Harg-Sam O. \\
\hline 1 - 2 years & 15 & 90 & 88 & 62 & 27 & 282 & 360 & 362 & 239 & 285 & 556 & 315 & 260 & 312 \\
\hline 3 - 5 years & 20 & 120 & 118 & 82 & 36 & 376 & 481 & 483 & 319 & 380 & 741 & 420 & 347 & 416 \\
\hline 6 - 10 years & 27 & 160 & 158 & 110 & 48 & 504 & 644 & 647 & 428 & 509 & 992 & 562 & 464 & 558 \\
\hline$>10$ years & 40 & 240 & 236 & 165 & 72 & 752 & 961 & 966 & 639 & 760 & 1482 & 839 & 693 & 833 \\
\hline Nabeul & 1 & 2 & 3 & 4 & 5 & $\mathrm{PM}$ & $\mathrm{PO}$ & $\mathrm{BC}$ & Turc & STand SW & EAG & Ivanov & Chr-Harg & Harg-Sam O. \\
\hline 1 - 2 years & 21 & 94 & 83 & 74 & 44 & 317 & 378 & 497 & 291 & 366 & 678 & 353 & 353 & 258 \\
\hline 3 - 5 years & 28 & 126 & 111 & 99 & 59 & 423 & 505 & 662 & 389 & 488 & 904 & 471 & 470 & 344 \\
\hline 6 - 10 years & 38 & 168 & 149 & 132 & 79 & 566 & 676 & 887 & 521 & 654 & 1211 & 631 & 630 & 461 \\
\hline$>10$ years & 56 & 251 & 223 & 198 & 118 & 846 & 1009 & 1325 & 777 & 977 & 1809 & 942 & 941 & 688 \\
\hline Tunis & 1 & 2 & 3 & 4 & 5 & $\mathrm{PM}$ & $\mathrm{PO}$ & $\mathrm{BC}$ & Turc & STand SW & EAG & Ivanov & Chr-Harg & Harg-Sam O. \\
\hline 1 - 2 years & 18 & 95 & 88 & 68 & 36 & 304 & 370 & 371 & 263 & 320 & 602 & 279 & 307 & 277 \\
\hline 3 - 5 years & 24 & 126 & 117 & 90 & 48 & 405 & 494 & 495 & 351 & 426 & 803 & 373 & 410 & 369 \\
\hline 6 - 10 years & 32 & 169 & 157 & 121 & 64 & 543 & 661 & 663 & 470 & 571 & 1075 & 499 & 549 & 494 \\
\hline$>10$ years & 48 & 252 & 234 & 181 & 95 & 810 & 987 & 989 & 701 & 852 & 1606 & 745 & 819 & 738 \\
\hline Sidi Bouzid & 1 & 2 & 3 & 4 & 5 & $\mathrm{PM}$ & $\mathrm{PO}$ & BC & Turc & STand SW & EAG & Ivanov & Chr-Harg & Harg-Sam O. \\
\hline 1 - 2 years & 21 & 99 & 88 & 69 & 41 & 317 & 362 & 420 & 254 & 312 & 611 & 316 & 302 & 291 \\
\hline 3 - 5 years & 27 & 132 & 117 & 92 & 54 & 423 & 483 & 560 & 338 & 417 & 815 & 422 & 402 & 389 \\
\hline $6-10$ years & 37 & 177 & 157 & 123 & 72 & 566 & 647 & 749 & 453 & 558 & 1092 & 565 & 539 & 520 \\
\hline$>10$ years & 55 & 265 & 234 & 184 & 108 & 845 & 966 & 1119 & 676 & 833 & 1630 & 843 & 805 & 777 \\
\hline Gabes & 1 & 2 & 3 & 4 & 5 & $\mathrm{PM}$ & $\mathrm{PO}$ & $\mathrm{BC}$ & Turc & STand SW & EAG & Ivanov & Chr-Harg & Harg-Sam O. \\
\hline 1 - 2 years & 23 & 100 & 83 & 81 & 49 & 335 & 378 & 497 & 291 & 366 & 678 & 353 & 353 & 258 \\
\hline 3 - 5 years & 30 & 133 & 111 & 107 & 65 & 447 & 505 & 662 & 389 & 488 & 904 & 471 & 470 & 344 \\
\hline 6 - 10 years & 41 & 178 & 149 & 144 & 87 & 599 & 676 & 887 & 521 & 654 & 1211 & 631 & 630 & 461 \\
\hline$>10$ years & 61 & 266 & 223 & 215 & 130 & 894 & 1009 & 1325 & 777 & 977 & 1809 & 942 & 941 & 688 \\
\hline
\end{tabular}


Maximum estimates are those obtained by the Eagleman formula.

Lysimetric values determined by Nasr (2002) [1] representing the effective need of water are significantly lower than ETC computed with the PM-formula (ETC-PM) for Tunis, Nabeul, Sousse and Gabes, which are coastal areas. Annual ratios between the lysimetric values and ETc ranged between 0.74 and 0.96 for these areas and approximate the unit for both Béja and Sidi Bouzid as shown in Table 14.

\subsection{Water Deficit and Irrigation Amounts Following Location}

Annual and seasonal values of (P-ETc) computed for all sites are reported in Tables 15-21. Negative values represent the amount of water needed by trees over the year or the irrigation period (May-September) to complement rainfall. Amounts of water available for the crop are designed by the sign $(+)$. Details for all sites are decribed as follows:

Tunis: At annual scale all methods allow recovery of the crop water needs of trees aged one to five years except that of Eagleman. But this result is not suitable for such plantations at seasonal scale. Indeed, all values of (P-ETC) are negative even for the youngest orchards. The lowest difference between rainfall $\mathrm{R}$ and ETc is recorded with the Ivanov method $(-72 \mathrm{~mm})$. Thus the seasonal rainfall amounts are not suffisant to meet the crop water needs for all tranches of age. The method of Turc, recorded previously as the most appropriate for this region allow recovery of the crop water needs of olive plantations aged one to ten years at annual scale and provide low differences between $\mathrm{R}$ and ETc at seasonal scale. The amount of water needed at seasonal scale varies from $76 \mathrm{~mm}$ to $344 \mathrm{~mm}$ depending on age.

Nabeul: At annual scale all methods allow recovery of the crop water needs of trees aged one to two years except those of Eagleman and PO. All seasonal values of (P-ETc) are negative. The Ivanov method provides the lowest water deficit. Irrigation is needed for all kind of olive plantations from May to September. The amount of

Table 14. Ratio between the lysimetric values and ETc $(\mathrm{mm})$ following the site and the growing period.

\begin{tabular}{cccccccc}
\hline & M & A-J & Jt-A & S-N & D-F & Annual \\
Tunis & 1 & 2 & 3 & 4 & 5 & Cycle \\
Nabeul & 0.74 & 0.96 & 0.92 & 0.80 & 0.64 & 0.86 \\
Sousse & 0.83 & 0.86 & 0.82 & 0.70 & 0.56 & 0.77 \\
Gabes & 0.83 & 0.90 & 0.93 & 0.93 & 0.77 & 0.89 \\
\hline
\end{tabular}

Table 15. Annual and Seasonal water deficits (P-ETc, mm) at the site of Tunis.

\begin{tabular}{|c|c|c|c|c|c|c|c|c|c|c|}
\hline \multicolumn{11}{|c|}{ Annual water needs (mm) } \\
\hline $\begin{array}{c}\text { Method } \\
\text { Age (Year) }\end{array}$ & PM & $\mathrm{PO}$ & $\mathrm{BC}$ & Turc & ST and SW & EAG & Ivanov & Chr Harg & Har Sam O. & Lysimeter \\
\hline $1-2$ & +178.2 & +111.8 & +111.0 & +219.0 & +162.5 & -120.2 & +202.5 & +174.7 & +205.1 & +220.6 \\
\hline $3-5$ & +76.9 & -11.6 & -12.7 & +131.3 & +56.0 & -321.0 & +109.3 & +72.3 & +112.8 & +133.5 \\
\hline $6-10$ & -60.5 & -179.1 & -180.6 & +12.4 & -88.5 & -593.4 & -17.1 & +66.8 & -12.5 & +15.3 \\
\hline$>10$ & -382.2 & -505.2 & -507.4 & -219.3 & -370.0 & -1123.9 & -263.3 & -337.5 & -256.4 & -215.0 \\
\hline
\end{tabular}

\begin{tabular}{|c|c|c|c|c|c|c|c|c|c|c|}
\hline \multicolumn{11}{|c|}{ Seasonal water needs (mm) } \\
\hline $\begin{array}{c}\text { Method } \\
\text { Age (Year) }\end{array}$ & PM & PO & $\mathrm{BC}$ & Turc & ST and SW & EAG & Ivanov & Chr Harg & Har Sam O. & Lysimeter \\
\hline $1-2$ & -105.6 & -109.3 & -138.9 & -76.2 & -131.4 & -256.5 & -71.9 & -118.9 & -91.0 & -92.2 \\
\hline $3-5$ & -169.1 & -174.1 & -213.6 & -129.9 & -203.5 & -370.3 & -124.2 & -186.9 & -149.7 & -151.3 \\
\hline $6-10$ & -255.3 & -262.1 & -314.9 & -202.8 & -301.3 & -524.8 & -195.2 & -279.1 & -229.3 & -231.4 \\
\hline$>10$ & -423.1 & -433.3 & -512.1 & -344.8 & -491.9 & -825.7 & -333.4 & -458.7 & -384.4 & -387.5 \\
\hline
\end{tabular}


Table 16. Annual and Seasonal water deficit $(\mathrm{P}-E T c, \mathrm{~mm})$ at the site of Nabeul.

\begin{tabular}{|c|c|c|c|c|c|c|c|c|c|c|}
\hline \multicolumn{11}{|c|}{ Annual water needs (mm) } \\
\hline $\begin{array}{c}\text { Method } \\
\text { Age (Year) }\end{array}$ & PM & $\mathrm{PO}$ & BC & Turc & ST and SW & EAG & Ivanov & Chr Harg & Har Sam O. & Lysimeter \\
\hline $1-2$ & +71 & -46 & +52 & +136 & +83 & -227 & +175 & +123 & +150 & +145 \\
\hline $3-5$ & -35 & -191 & -60 & +52 & -19 & -432 & +103 & +35 & +70 & +64 \\
\hline $6-10$ & -178 & -387 & -211 & -62 & -157 & -710 & +7 & -85 & -37 & -46 \\
\hline$>10$ & -458 & -770 & -507 & -285 & -425 & -1251 & -181 & -318 & -247 & -260 \\
\hline \multicolumn{11}{|c|}{ Seasonal water needs (mm) } \\
\hline $\begin{array}{c}\text { Method } \\
\text { Age (Year) }\end{array}$ & PM & $\mathrm{PO}$ & $\mathrm{BC}$ & Turc & ST and SW & EAG & Ivanov & Chr Harg & Har Sam O. & Lysimeter \\
\hline $1-2$ & -115 & -154 & -133 & -83 & -133 & -270 & -40 & -101 & -77 & -81 \\
\hline $3-5$ & -177 & -229 & -201 & -134 & -201 & -383 & -77 & -157 & -126 & -132 \\
\hline $6-10$ & -261 & -330 & -292 & -203 & -293 & -537 & -127 & -234 & -192 & -200 \\
\hline$>10$ & -424 & -528 & -471 & -337 & -472 & -836 & -224 & -385 & -321 & -334 \\
\hline
\end{tabular}

Table 17. Annual and Seasonal water deficit (P-ETc, mm) at the site of Sidi Bouzid.

\begin{tabular}{ccccccccccc}
\hline \multicolumn{2}{c}{ Annual water needs (mm) } & & & & & & & & \\
\hline Method Age (Year) & PM & PO & BC & Turc & ST and SW & EAG & Ivanov & Chr Harg & Harg Sam O. Lysimeter \\
\hline $1-2$ & -71 & -116 & -174 & -8 & -66 & -365 & -138 & -63 & -83 & -87 \\
$3-5$ & -177 & -237 & -314 & -92 & -171 & -569 & -266 & -166 & -193 & -198 \\
$6-10$ & -320 & -401 & -503 & -207 & -312 & -846 & -440 & -306 & -341 & -348 \\
$>10$ & -599 & -720 & -873 & -430 & -587 & -1384 & -778 & -579 & -631 & -641
\end{tabular}

Seasonal water needs $(\mathrm{mm})$

\begin{tabular}{ccccccccccc} 
Method Age (Year) & PM & PO & BC & Turc & ST and SW & EAG & Ivanov & Chr Harg & Har Sam O. & Lysimeter \\
$1-2$ & -113 & -103 & -157 & -74 & -131 & -272 & -148 & -116 & -129 & -86 \\
$3-5$ & -177 & -164 & -236 & -125 & -201 & -389 & -224 & -181 & -199 & -141 \\
$6-10$ & -264 & -247 & -343 & -195 & -297 & -548 & -327 & -269 & -294 & -216 \\
$>10$ & -434 & -409 & -552 & -330 & -483 & -858 & -527 & -442 & -478 & -362 \\
\hline
\end{tabular}

water needed at seasonal scale varies from $40 \mathrm{~mm}$ to $224 \mathrm{~mm}$ depending on age.

Sidi Bouzid: The deficit of water is recorded at both annual and seasonal scales. Rainfall amounts are not suffisant to cover the crop water needs even those of one and two years old plantations. Irrigation is thus needed for all kinds of olive orchards. The method giving the lowest value of (P-ETc) is that of Turc. The amount of water needed at seasonal scale varies from $74 \mathrm{~mm}$ to $330 \mathrm{~mm}$ depending on age.

Sousse: At annual scale all methods allow recovery of the crop water needs of trees aged one and two years except that of Eagleman. At seasonal scale, the deficit is present for all tranches of age with lowest differences recorded for both methods: Turc and Chr. Harg. Seasonal rainfall is not suffisant to cover the crop water needs and irrigation is needed from May to September with amounts ranging between $95 \mathrm{~mm}$ and $351 \mathrm{~mm}$ depending on age.

Gabès: Water deficit is present at seasonal and annual scale. The rainfall amounts are not high enougth to meet the crop water needs even for young plantations. The most valuable method giving the lowest deficit is that of Harg. Sam. Irrigation is requested at seasonal scale with amounts ranging between $128 \mathrm{~mm}$ and $374 \mathrm{~mm}$ depending on tree age. 
Table 18. Annual and Seasonal water deficit $(\mathrm{P}-E T c, \mathrm{~mm})$ at the site of Soussse.

\begin{tabular}{|c|c|c|c|c|c|c|c|c|c|c|}
\hline \multicolumn{11}{|c|}{ Annual water needs (mm) } \\
\hline $\begin{array}{c}\text { Method } \\
\text { Age (Year) }\end{array}$ & $\mathrm{PM}$ & $\mathrm{PO}$ & $\mathrm{BC}$ & Turc & ST and SW & EAG & Ivanov & Chr Harg & Harg Sam O. & Lysimeter \\
\hline $1-2$ & +50 & +13 & +27 & +114 & +54 & -271 & +56 & +133 & +111 & +85 \\
\hline $3-5$ & -59 & -107 & -89 & +27 & -53 & -487 & -50 & +52 & +23 & -12 \\
\hline $6-10$ & -206 & -272 & -247 & -91 & -198 & -779 & -195 & -58 & -97 & -144 \\
\hline$>10$ & -494 & -591 & -555 & -322 & -482 & -1349 & -476 & -273 & -331 & -401 \\
\hline \multicolumn{11}{|c|}{ Seasonal water needs (mm) } \\
\hline $\begin{array}{c}\text { Method } \\
\text { Age (Year) }\end{array}$ & $\mathrm{PM}$ & $\mathrm{PO}$ & BC & Turc & ST and SW & EAG & Ivanov & Chr Harg & Harg Sam O. & Lysimeter \\
\hline $1-2$ & -130 & -130 & -140 & -96 & -151 & -303 & -114 & -95 & -105 & -120 \\
\hline $3-5$ & -192 & -193 & -205 & -147 & -220 & -423 & -170 & -145 & -159 & -179 \\
\hline $6-10$ & -277 & -277 & -294 & -216 & -314 & -585 & -247 & -214 & -232 & -259 \\
\hline$>10$ & -442 & -442 & -468 & -351 & -497 & -902 & -398 & -347 & -375 & -415 \\
\hline
\end{tabular}

Table 19. Annual and Seasonal water deficit (P-ETc, mm) at the site of Gabes.

\begin{tabular}{|c|c|c|c|c|c|c|c|c|c|c|}
\hline \multicolumn{11}{|c|}{ Annual water needs (mm) } \\
\hline $\begin{array}{c}\text { Method } \\
\text { Age (Year) }\end{array}$ & $\mathrm{PM}$ & $\mathrm{PO}$ & BC & Turc & ST and SW & EAG & Ivanov & Chr Harg & Har Sam O. & Lysimeter \\
\hline $1-2$ & -134 & -177 & -296 & -90 & -165 & -477 & -152 & -152 & -57 & -82 \\
\hline $3-5$ & -246 & -304 & -461 & -188 & -287 & -703 & -270 & -269 & -143 & -176 \\
\hline $6-10$ & -398 & -475 & -686 & -320 & -453 & -1010 & -430 & -429 & -260 & -304 \\
\hline$>10$ & -693 & -808 & -1124 & -576 & -776 & -1608 & -741 & -740 & -487 & -553 \\
\hline \multicolumn{11}{|c|}{ Seasonal water needs (mm) } \\
\hline $\begin{array}{l}\text { Method } \\
\text { Age (Year) }\end{array}$ & $\mathrm{PM}$ & PO & $\mathrm{BC}$ & Turc & ST and SW & EAG & Ivanov & Chr Harg & Har Sam O. & Lysimeter \\
\hline $1-2$ & -171 & -178 & -254 & -148 & -212 & -355 & -157 & -196 & -128 & -151 \\
\hline $3-5$ & -235 & -244 & -346 & -204 & -289 & -480 & -216 & -267 & -177 & -208 \\
\hline $6-10$ & -321 & -333 & -469 & -279 & -394 & -649 & -295 & -364 & -244 & -285 \\
\hline$>10$ & -488 & -507 & -710 & -427 & -598 & -978 & -450 & -553 & -374 & -435 \\
\hline
\end{tabular}

Bizerte: At annual scale all methods allow recovery of the crop water needs of trees aged one to five years except that of Eagleman. Other methods like that of Turc allow also recovery of water needs of older trees, to ten years old. Thus, irrigation is needed during the fruit growth season with amounts ranging between $72 \mathrm{~mm}$ and $323 \mathrm{~mm}$ depending on age, computed with the method of Ivanov wich provid the lowest deficits.

Béja: At annual scale all methods allow recovery of the crop water needs of trees aged one to five years except that of Eagleman. The most appropriate formula is that of Turc providing the lowest deficit. Irrigation should be applied during summer months from May to September with amounts of water ranging between 49 $\mathrm{mm}$ and $296 \mathrm{~mm}$ depending on tree age.

The method of Turc appears as the most appropriate for Tunis, Sousse, Sidi Bouzid and Béja while the method of Ivanov is adaquate for Bizerte and Nabeul. For Gabes the method of Harg Sam gave the most adequate values. The main climatic data requested are temperature, humidity and insolation, which are available in most stations. These formulas can be used specifically for these stations when the climatic data are not available to compute $\mathrm{ET}_{0}-\mathrm{PM}$, particularly the solar radiation. 
Table 20. Annual and Seasonal water deficit $(\mathrm{P}-E T c, \mathrm{~mm})$ at the site of Bizerte.

\begin{tabular}{|c|c|c|c|c|c|c|c|c|c|c|}
\hline \multicolumn{11}{|c|}{ Annual water needs (mm) } \\
\hline $\begin{array}{c}\text { Method } \\
\text { Age (Year) }\end{array}$ & PM & $\mathrm{PO}$ & BC & Turc & ST and SW & EAG & Ivanov & Chr Harg & Har Sam O. & Lysimeter \\
\hline $1-2$ & +360 & +271 & +279 & +383 & +330 & +70 & +386 & +350 & +384 & \\
\hline $3-5$ & +256 & +146 & +157 & +295 & +226 & -121 & +299 & +251 & +298 & \\
\hline $6-10$ & +137 & -23 & -8 & +177 & +83 & -381 & +182 & +118 & +180 & \\
\hline$>10$ & -114 & -352 & -330 & -54 & -194 & -887 & -46 & -142 & -50 & \\
\hline \multicolumn{11}{|c|}{ Seasonal water needs $(\mathrm{mm})$} \\
\hline $\begin{array}{c}\text { Method } \\
\text { Age (Year) }\end{array}$ & PM & $\mathrm{PO}$ & BC & Turc & ST and SW & EAG & Ivanov & Chr Harg & Har Sam O. & Lysimeter \\
\hline $1-2$ & -100 & -119 & -147 & -84 & -136 & -245 & -72 & -119 & -86 & \\
\hline $3-5$ & -160 & -185 & -222 & -139 & -208 & -352 & -123 & -184 & -141 & \\
\hline $6-10$ & -241 & -274 & -324 & -212 & -305 & -498 & -191 & -273 & -216 & \\
\hline$>10$ & -398 & -448 & -523 & -355 & -494 & -783 & -323 & -446 & -361 & \\
\hline
\end{tabular}

Table 21. Annual and Seasonal water deficit (P-ETc, $\mathrm{mm})$ at the site of Béja.

\begin{tabular}{|c|c|c|c|c|c|c|c|c|c|c|}
\hline \multicolumn{11}{|c|}{ Annual water needs (mm) } \\
\hline $\begin{array}{c}\text { Method } \\
\text { Age (Year) }\end{array}$ & $\mathrm{PM}$ & $\mathrm{PO}$ & $\mathrm{BC}$ & Turc & ST and SW & EAG & Ivanov & Chr Harg & Har Sam O. & Lysimeter \\
\hline $1-2$ & +296 & +218 & +216 & +339 & +293 & +22 & +263 & +318 & +266 & +288 \\
\hline $3-5$ & +202 & +97 & +95 & +259 & +198 & -163 & +158 & +231 & +162 & +192 \\
\hline $6-10$ & +74 & -66 & -69 & +150 & +69 & -414 & +16 & +114 & +20 & +61 \\
\hline$>10$ & -174 & -383 & -388 & -61 & -182 & -904 & -261 & -115 & -255 & -195 \\
\hline
\end{tabular}

Seasonal water needs (mm)

\begin{tabular}{ccccccccccc}
$\begin{array}{c}\text { Method } \\
\text { Age (Year) }\end{array}$ & PM & PO & BC & Turc & ST and SW & EAG & Ivanov & Chr Harg & Har Sam O. & Lysimeter \\
$1-2$ & -88 & -86 & -124 & -49 & -97 & -220 & -101 & -75 & $-\mathbf{1 0 5}$ & -92 \\
$3-5$ & -151 & -148 & -199 & -98 & -162 & -326 & -168 & -133 & $-\mathbf{1 7 3}$ & -156 \\
$6-10$ & -236 & -232 & -300 & -165 & -251 & -471 & -258 & -212 & $-\mathbf{2 6 5}$ & -243 \\
$>10$ & -402 & -395 & -498 & -296 & -424 & -753 & -435 & -367 & $-\mathbf{4 4 5}$ & -413 \\
\hline
\end{tabular}

Values of (ETC-P) computed for the irrigation season, from May to September, are negatives. The deficit of water is present even for young plantations. Rainfall amounts were insuffisant to meet the crop water needs of this species during the period of fruit growth. These amounts should be supplied by irrigation. The lowest deficit is observed at Béja and the highest at Gabes. At annual scale, values of (ETC-P) are positive for Tunis, Nabeul, Sousse, Bizerte and Beja when young olive plantations are considered. For older trees, values are positive only for the northern areas of Tunis, Bizerte and Béja. This last location is the only case where water needs are covered for olive trees aged 6 to 10 years. So there is a need for irrigating olive plantations aging more than 5 years and especially when olive is cultivated in the western areas. Irrigation is needed during the growing fruit period but also during the other seasons, when shoots grow.

\subsection{Rainfall Distribution Functions and Recovery of Crop Water Needs}

Rainfall distribution functions were established for each city following the growing periods (Figure 7).

Rainfall distribution functions present different evolutionary. For rainy regions like Béja, Nabeul and Bizerte, 

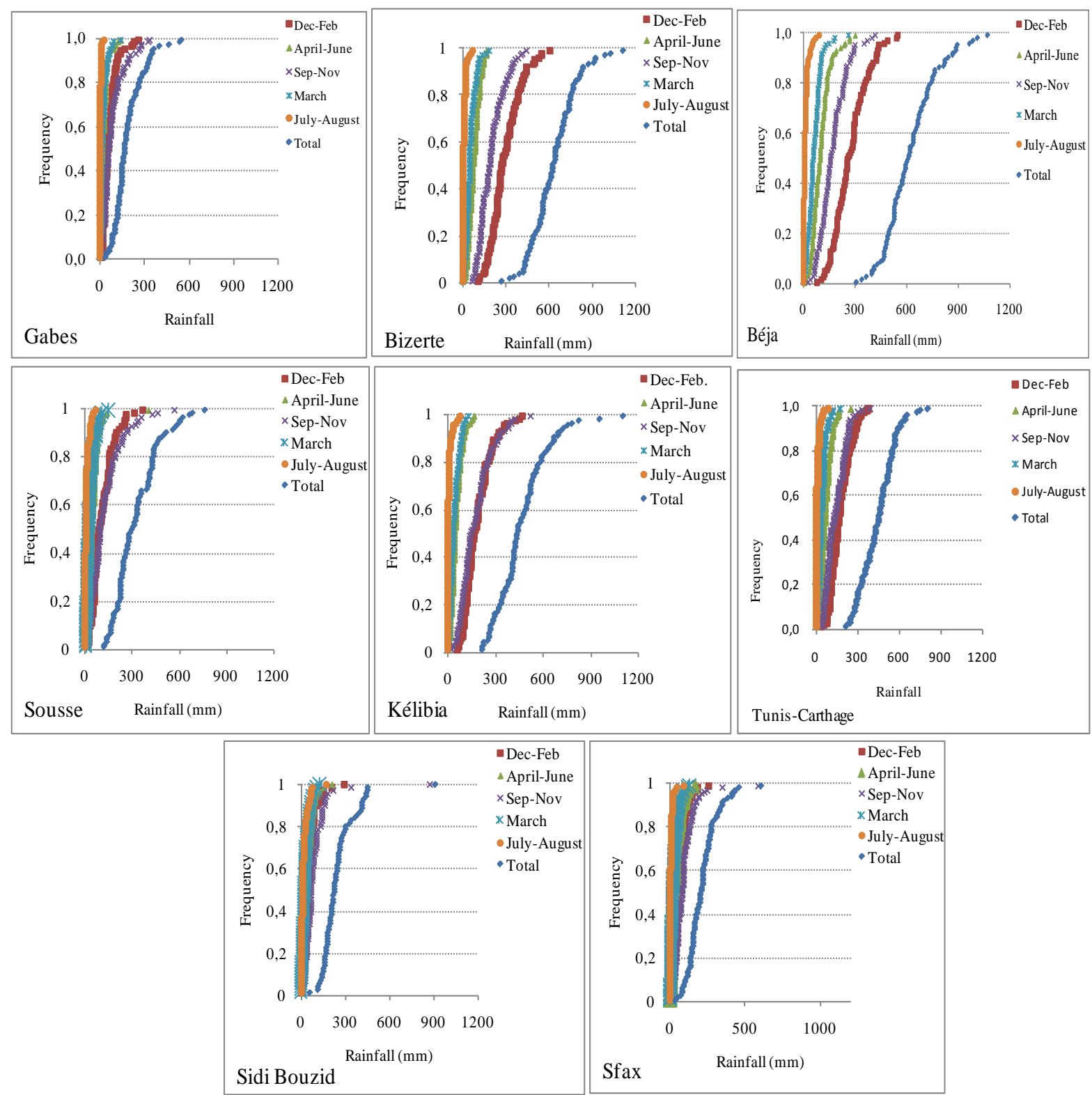

Figure7. Rainfall distribution functions following site of olive cultivation and the growing periods.

the curves looks separate, while those of Gabes and Sidi Bouzid are close one another. On the basis of these seasonal and annual distributions of rainfall, the frequencies of non-satisfactory were determined following tree age and location. Values are reported in Table 22. As shown in the following table, the frequencies of non-satisfactory (F) vary consistently from location to another and following the growing period. During July-August, F values exceed 0.9 in all cases and only $10 \%$ of water needs are supplied by rainfall even for the rainiest areas like Bizerte. For young trees aged one to five years, rainfall amounts meet excactly the crop water needs at Béja and Bizerte. Rainfall amounts cover 60\% to 85\% ETc of trees aged 6 to 10 years at Bizerte and Béja and trees aged one to five years at Nabeul and Tunis. About 50\% ETC of one year old trees are covered by rainfall at Sousse. Less than $20 \%$ of water needs are covered at Bizerte and Béja for old trees aged more than 10 years, at Nabeul and Tunis for trees aged 6 to 10 years, at Sousse for trees aging 3 to 5 years and at Sidi Bouzid for of one year and two years old trees.

It appears from these results based on the seasonal rainfall frequencies and water needs computed with the PM formula that irrigation supply is necessary all time for trees aging more than 10 years even for the rainiest 
Table 22. Frequencies of non-satisfactory of water needs following age and location.

\begin{tabular}{|c|c|c|c|c|c|c|c|c|c|c|c|c|}
\hline Bizerte & 1 & $\mathbf{F}$ & 2 & $\mathbf{F}$ & 3 & $\mathbf{F}$ & 4 & $\mathbf{F}$ & 5 & $\mathrm{~F}$ & $\mathbf{T}$ & $\mathbf{F}$ \\
\hline 1 - 2 years & 17 & 0.101 & 87 & 0.611 & 83 & 0.917 & 64 & 0.009 & 34 & 0.008 & 285 & 0.011 \\
\hline 3 - 5 years & 23 & 0.148 & 116 & 0.828 & 110 & 0.999 & 85 & 0.050 & 45 & 0.005 & 380 & 0.038 \\
\hline 6 - 10 years & 30 & 0.216 & 156 & 0.945 & 148 & 0.999 & 114 & 0.150 & 60 & 0.004 & 508 & 0.216 \\
\hline$>10$ years & 45 & 0.441 & 233 & 0.990 & 221 & 0.999 & 170 & 0.409 & 90 & 0.003 & 759 & 0.815 \\
\hline Sousse & 1 & $\mathbf{F}$ & 2 & $\mathbf{F}$ & 3 & $\mathbf{F}$ & 4 & F & 5 & $\mathrm{~F}$ & $\mathbf{T}$ & $\mathbf{F}$ \\
\hline 1 - 2 years & 22 & 0.440 & 95 & 0.905 & 84 & 0.999 & 79 & 0.353 & 46 & 0.15 & 326 & 0.541 \\
\hline 3 - 5 years & 29 & 0.590 & 127 & 0.958 & 112 & 0.999 & 106 & 0.541 & 61 & 0.29 & 435 & 0.818 \\
\hline 6 - 10 years & 39 & 0.740 & 170 & 0.999 & 150 & 0.999 & 142 & 0.673 & 82 & 0.471 & 582 & 0.924 \\
\hline$>10$ years & 58 & 0.840 & 254 & 0.999 & 224 & 0.999 & 211 & 0.860 & 122 & 0.64 & 870 & 0.990 \\
\hline Béja & 1 & $\mathbf{F}$ & 2 & $\mathbf{F}$ & 3 & $\mathbf{F}$ & 4 & $\mathbf{F}$ & 5 & $\mathrm{~F}$ & $\mathbf{T}$ & F \\
\hline 1 - 2 years & 15 & 0.083 & 90 & 0.446 & 88 & 0.990 & 62 & 0.039 & 27 & 0.003 & 282 & 0.009 \\
\hline 3 - 5 years & 20 & 0.104 & 120 & 0.687 & 118 & 0.999 & 82 & 0.134 & 36 & 0.005 & 376 & 0.031 \\
\hline 6 - 10 years & 27 & 0.193 & 160 & 0.879 & 158 & 0.999 & 110 & 0.299 & 48 & 0.006 & 504 & 0.218 \\
\hline$>10$ years & 40 & 0.268 & 240 & 0.960 & 236 & 0.999 & 165 & 0.521 & 72 & 0.009 & 752 & 0.822 \\
\hline Nabeul & 1 & $\mathbf{F}$ & 2 & $\mathbf{F}$ & 3 & $\mathbf{F}$ & 4 & $\mathbf{F}$ & 5 & $\mathrm{~F}$ & $\mathbf{T}$ & $\mathbf{F}$ \\
\hline 1 - 2 years & 21 & 0.282 & 94 & 0.884 & 83 & 0.990 & 74 & 0.117 & 44 & 0.000 & 317 & 0.175 \\
\hline 3 - 5 years & 28 & 0.376 & 126 & 0.886 & 111 & 0.999 & 99 & 0.248 & 59 & 0.009 & 423 & 0.427 \\
\hline 6 - 10 years & 38 & 0.547 & 168 & 0.990 & 149 & 0.999 & 132 & 0.411 & 79 & 0.048 & 566 & 0.782 \\
\hline$>10$ years & 56 & 0.723 & 251 & 0.999 & 223 & 0.999 & 198 & 0.615 & 118 & 0.203 & 846 & 0.960 \\
\hline Tunis & 1 & $\mathbf{F}$ & 2 & $\mathbf{F}$ & 3 & $\mathbf{F}$ & 4 & $\mathbf{F}$ & 5 & $\mathrm{~F}$ & $\mathbf{T}$ & $\mathbf{F}$ \\
\hline 1 - 2 years & 18 & 0.163 & 95 & 0.761 & 88 & 0.945 & 68 & 0.150 & 36 & 0.011 & 304 & 0.171 \\
\hline 3 - 5 years & 24 & 0.284 & 126 & 0.850 & 117 & 0.999 & 90 & 0.275 & 48 & 0.015 & 405 & 0.370 \\
\hline 6 - 10 years & 32 & 0.398 & 169 & 0.980 & 157 & 0.999 & 121 & 0.456 & 64 & 0.021 & 543 & 0.768 \\
\hline$>10$ years & 48 & 0.598 & 252 & 0.990 & 234 & 0.999 & 181 & 0.668 & 95 & 0.089 & 810 & 0.990 \\
\hline Sidi Bouzid & 1 & $\mathbf{F}$ & 2 & $\mathbf{F}$ & 3 & $\mathbf{F}$ & 4 & $\mathbf{F}$ & 5 & $\mathrm{~F}$ & $\mathbf{T}$ & $\mathbf{F}$ \\
\hline 1 - 2 years & 21 & 0.479 & 99 & 0.909 & 88 & 0.999 & 69 & 0.499 & 41 & 0.37 & 317 & 0.790 \\
\hline 3 - 5 years & 27 & 0.593 & 132 & 0.846 & 117 & 0.999 & 92 & 0.666 & 54 & 0.56 & 423 & 0.930 \\
\hline 6 - 10 years & 37 & 0.732 & 177 & 0.860 & 157 & 0.999 & 123 & 0.764 & 72 & 0.74 & 566 & 0.930 \\
\hline$>10$ years & 55 & 0.832 & 265 & 0.999 & 234 & 0.999 & 184 & 0.984 & 108 & 0.953 & 845 & 0.934 \\
\hline Gabes & 1 & $\mathbf{F}$ & 2 & $\mathbf{F}$ & 3 & $\mathbf{F}$ & 4 & $\mathbf{F}$ & 5 & $\mathrm{~F}$ & $\mathbf{T}$ & $\mathbf{F}$ \\
\hline 1 - 2 years & 23 & 0.694 & 100 & 0.843 & 83 & 0.999 & 81 & 0.653 & 49 & 0.496 & 335 & 0.916 \\
\hline 3 - 5 years & 30 & 0.782 & 133 & 0.929 & 111 & 0.999 & 107 & 0.713 & 65 & 0.605 & 447 & 0.942 \\
\hline 6 - 10 years & 41 & 0.880 & 178 & 0.999 & 149 & 0.999 & 144 & 0.814 & 87 & 0.780 & 599 & 0.999 \\
\hline$>10$ years & 61 & 0.952 & 266 & 0.999 & 223 & 0.999 & 215 & 0.826 & 130 & 0.860 & 894 & 0.999 \\
\hline
\end{tabular}

NB: Period 1: March; Period 2: April-June; Period 3: July-August; Period 4: September-November and Period 5: December-February. Only the PM formula is adopted for ETc estimation. 
locations as Bizerte and Béja where $20 \%$ only of the water needs are satisfied by rainfall. For younger plantations, irrigation becomes necessary beginning from the second period of development, i.e. April-June for Bizerte, Béja, Nabeul and Tunis. For the other stations, and particularly for Gabes and Sidi-Bouzid, irrigation is necessary for both young and old trees during the early spring period.

Figures 8-11 present the annual and seasonal distribution of rainfall expressed in terms of frequencies with
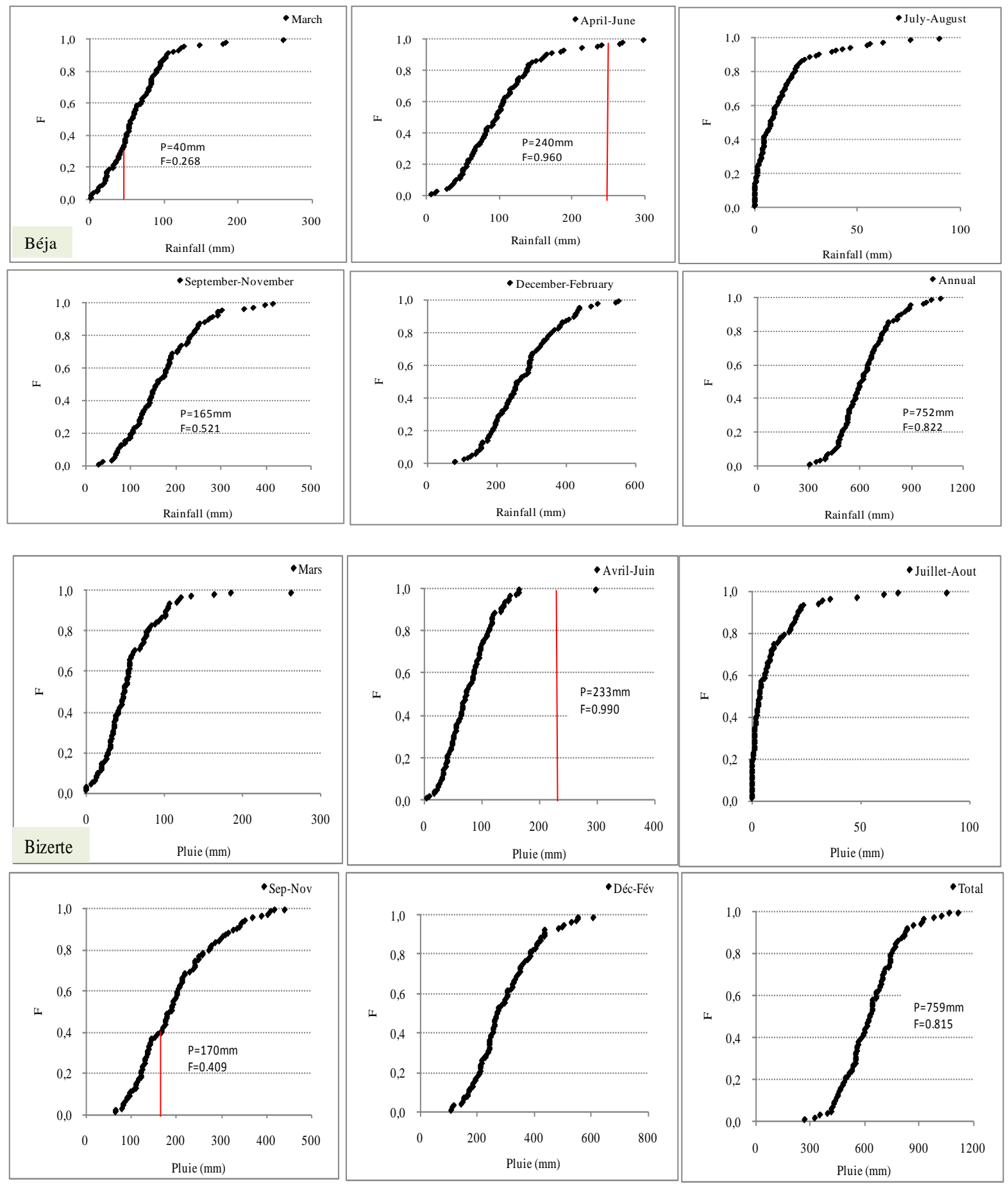

Figure 8. Rainfall distribution functions established for the sites of Béja and Bizerte with series of data recorded during 90 years-long-period and following the growing periods. Bars represent the amount of water needed (ETc, mm) for each period computed with the $\mathrm{ET}_{0}$-PM formula for 10 years old trees. 

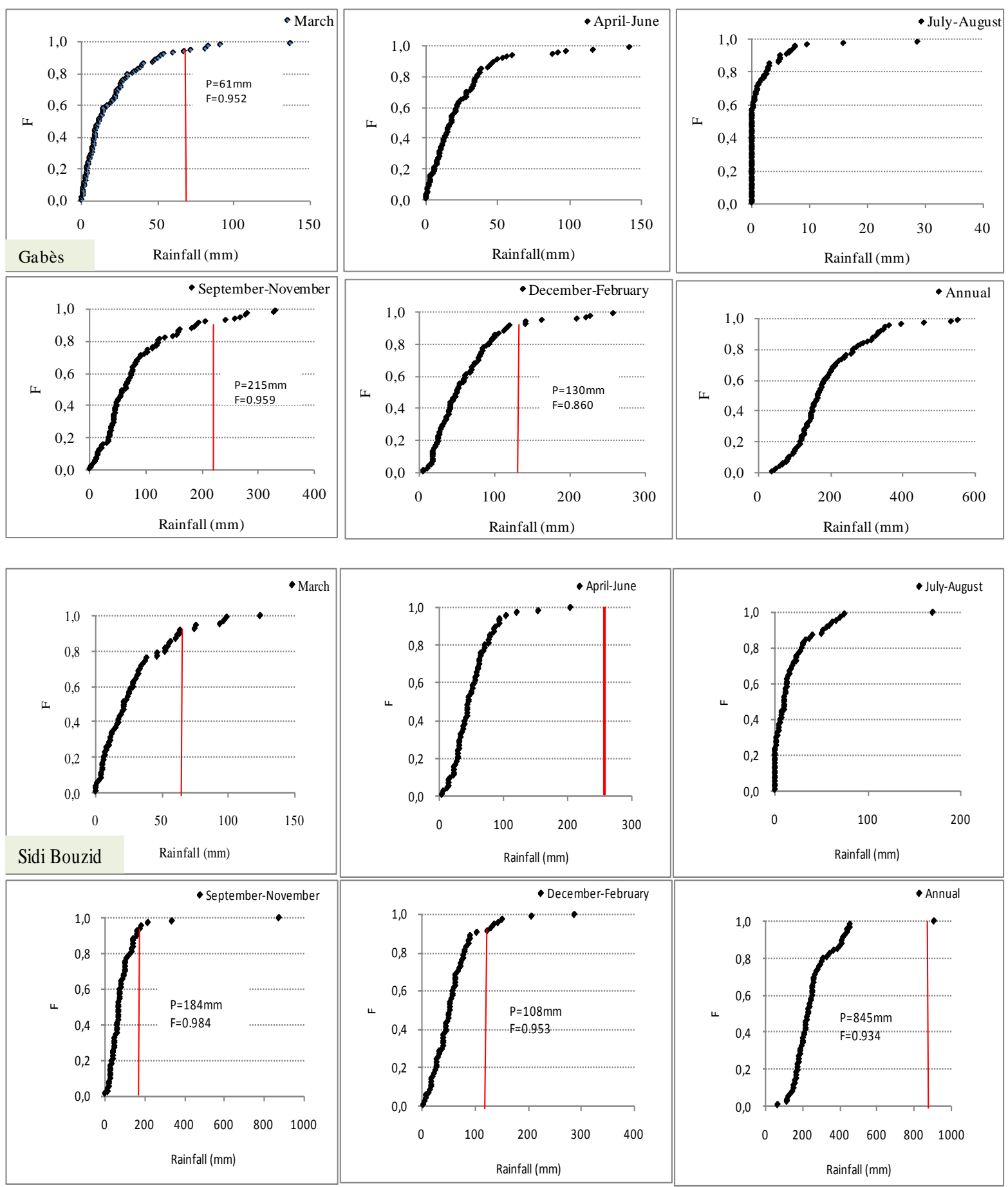

Figure 9. Rainfall distribution functions established for the sites of Gabes and Sidi Bouzid with series of data recorded during 90 years-long-period and following the growing periods. Bars represent the amount of water needed (ETc, mm) for each period computed with the $\mathrm{ET}_{0}$-PM formula for 10 years old trees.

bars representing the amount of water needed for each period of growth following the site.

Rainfall distribution functions established for the first growing period (March), for period 4 (September-November) and period 5 (December-February) showed that an important fraction of water needs, ranging between $60 \%$ and $90 \%$ is covered by rainfall supplies at Bizerte and Béja. For Nabeul and Tunis, Water amounts needed during stages 1, 4 and 5 for plants aged one to 10 years are correctly covered by rainfall. A similar situation 

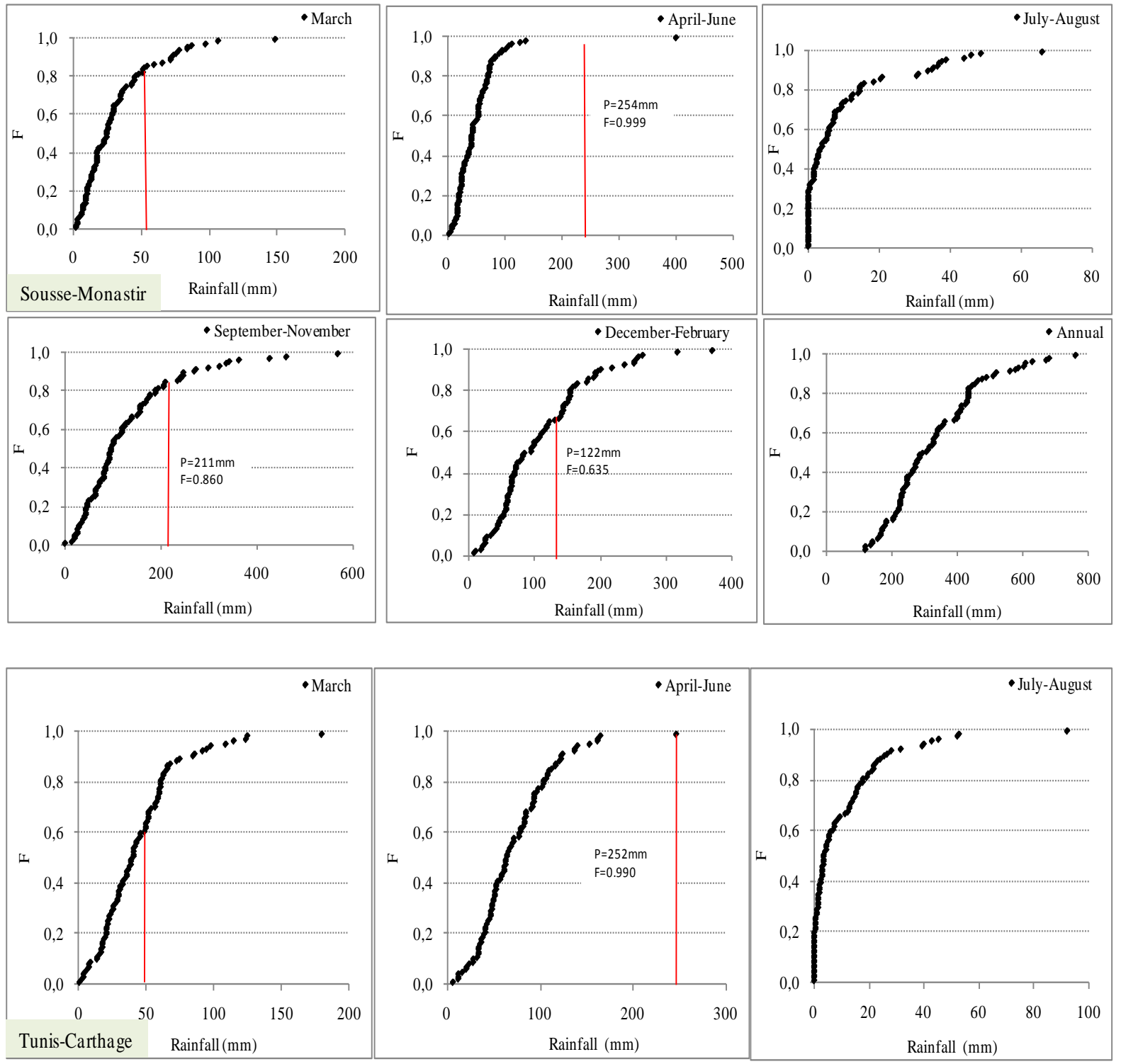

\begin{tabular}{rr} 
Tunis-Carthage $\quad$ Rainfall $(\mathrm{mm})$ \\
\hline$\bullet$ September-November
\end{tabular}
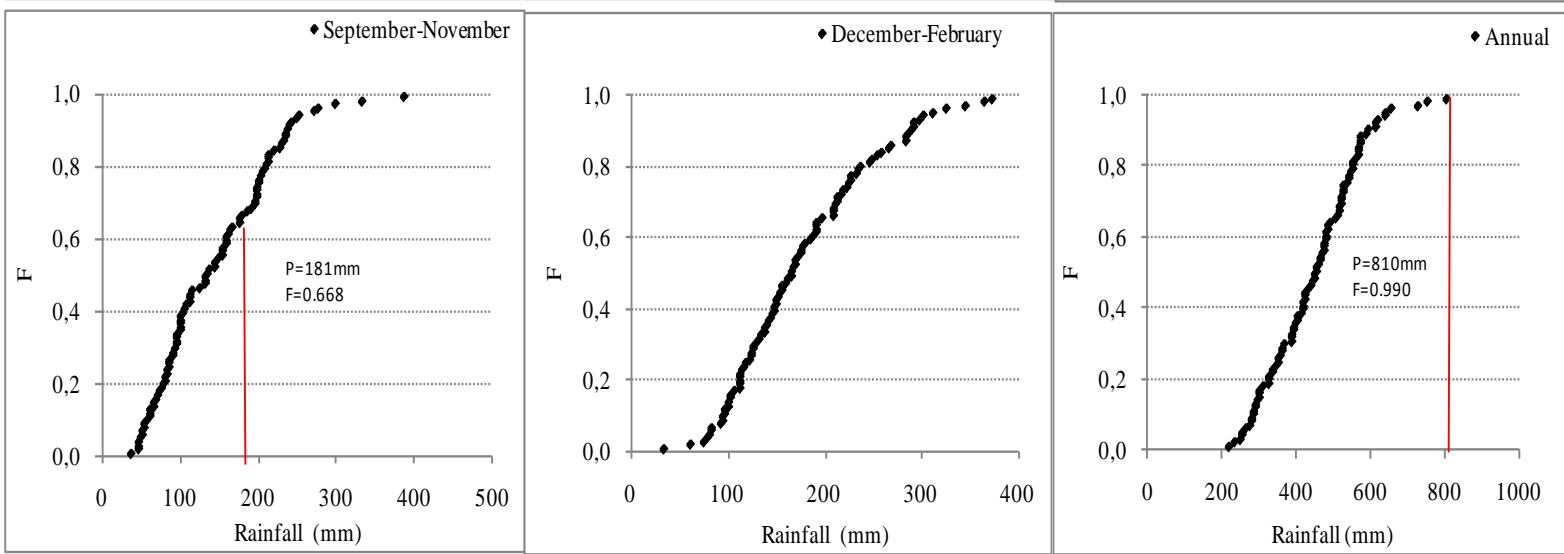

Figure 10. Rainfall distribution functions established for the sites of Sousse and Tunis with series of data recorded during 90 years-long-period and following the growing periods. Bars represent the amount of water needed $(E T c, \mathrm{~mm})$ for each period computed with the $\mathrm{ET}_{0}$-PM formula for 10 years old trees. 

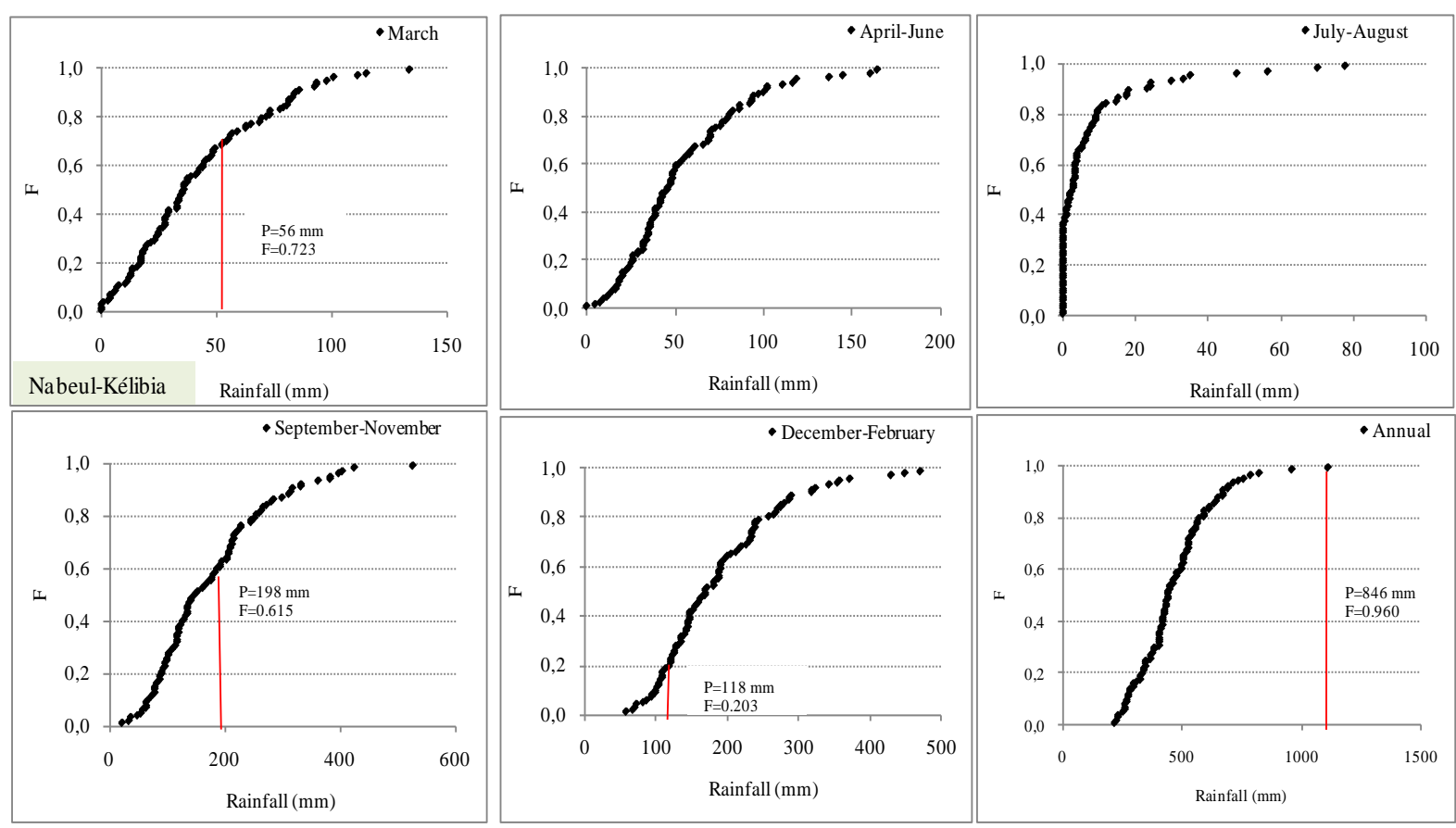

Figure 11. Rainfall distribution functions established for the site of Nabeul-Kélibia with series of data recorded during 90 years-long-period and following the growing periods. Bars represent the amount of water needed (ETc, mm) for each period computed with the $\mathrm{ET}_{0}$-PM formula for 10 years old trees.

is observed for Sousse where plantations aged one to five years are correctly supplied by rainfall received during stages 1,4 and 5 . For the other locations, less than $50 \%$ of water needs are covered by rainfall from September to March.

For the period of April-June, i.e., the period of flowering and early fruit development (period 2), rainfall amounts meet the crop water needs of young trees partially with a fraction ranging between $10 \%$ and $55 \%$ ( $40 \%$ at Bizerte, $10 \%$ at Monastir, 55\% at Béja, $15 \%$ at Nabeul, $24 \%$ at Tunis, $10 \%$ at Sidi Bouzid and $16 \%$ at Gabes). For adult plants amounts of rainfall are insufficient to cover their water requirements. Therefore irrigation is needed in most cases.

Rainfall amounts received during the summer period (period 3) are very low, not exceeding $10 \%$ of the crop water needs for all stations, and irrigation is needed even for one year old plants.

For the period of September-November (period 4), i.e., that of oil synthesis and harvest, annual water needs ranged between 62 and $215 \mathrm{~mm}$ following the age. Irrigation is necessary and particularly during the first weeks of this period particularly for Monastir, sidi Bouzid and Gabes where less than $60 \%$ of ETc of adult trees are covered.

Rainfall amounts received during winter (December-February, period 5) when flowers differenciate and fruits maturate cover more than $60 \%$ of young olive water needs even for the driest areas of Gabes and Sidi Bouzid. For Tunis, Béja, Bizerte and Nabeul, water needs are normally satisfied for all tranches of age.

\section{Discussion}

Aiming at a comparative analysis of the behaviour of the different methods of $\mathrm{ET}_{0}$ computation, their performance against the $\mathrm{ET}_{0}-\mathrm{PM}$ was evaluated in all considered cities through a set of commonly used statistics.

Results obtained from $\mathrm{ET}_{0}$ estimation by using different formulas show that the response differs following site, season and the calculation procedure. Analyses of data on differences between $\mathrm{ET}_{0}$ estimated with different formulas have shown that maximum estimates are provided by Eagleman and PO methods. The BC estimates are more often significantly superior to the other values. Minimum values are provided by ST and SW, Ivanov, Turc and Chr. Harg formulas depending on season and site. Significant differences were found between PO and

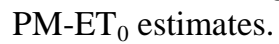

Values of $\mathrm{ET}_{0}$ computed by different empirical formulas and compared to the PM-estimates using full data- 
sets, show that the estimated $\mathrm{ET}_{0}$ values strongly correlate with $\mathrm{ET}_{0}-\mathrm{PM}$ at all stations with all formulas. However, the most appropriate methods are those of Turc and Ivanov, implying that these methods appropriately predict the $\mathrm{ET}_{0}$ in all climatic regions of Tunisia. A visual inspection of data suggests that the Turc method performs well for all climatic zones, arid and semi-arid, in western, northern and coastal areas of Tunisia. The Ivanov method appears to be more appropriate to the northen areas i.e. Béja and Bizerte. Estimates of $\mathrm{ET}_{0}$ by using the Hargreave-Samani (HS) equation for the east-southern area (Gabes) characterised by arid climate, show sa-

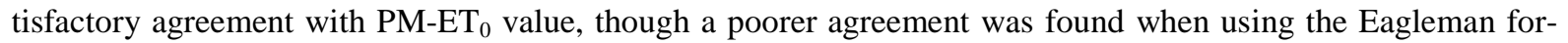
mula.

Results presented herein are coherent with previous findings [5] [82] [100] [101] comparing several evapotranspiration methods, particularly those made in Iran [24] [30] [32] [86], reporting that the HS method performs well in most climatic regions, with the exception of humid areas where it tends to overestimate $\mathrm{ET}_{0}$. The research works carried out around the Mediterranean basin show different responses. In Northern and Central Tunisia, Jabloun and Sahli (2008) [31] found better estimates for PM than for HS. Paredes and Rodrigues (2010) [102] found small errors with PM relative to HS, thus adopting it to estimate $\mathrm{ET}_{0}$ in Portugal for irrigation scheduling purposes; they found that estimation errors were larger in humid locations comparative to dryer ones. Temesgen et al., (2005) [100] stated that the HS method underestimates $\mathrm{ET}_{0}$ for dry and windy locations due to not considering a wind factor and concluded that it is more accurate when applied for 5 or 7-day averages than for daily time scales. Application of PM to different climates of South Africa showed to be superior to HS and that better results were obtained when applied to 5-day rather than daily time cales [29]. Differently, Martinez and Thepadia (2010) [32] found that the HS produced smaller overestimation errors than PM in a humid climate, while Gocic and Trajkovic (2010) [22] proposed software to estimate $\mathrm{ET}_{0}$ for minimizing computation errors using an adjusted HS equation when weather data are missing. Hargreaves and Allen (2003) and Razieia and Pereira (2013) [5]-[86] tend to explain these differences. Their explanation is based on a careful analysis of the history and applications of the HS equation, considering that as the HS method was developed initially for arid to sub-humid climates and thus it may not fit well to conditions of humid climates, necessitating different calibration with regard to the particularities of these climates. Droogers and Allen (2002) and Trajkovic (2007) [15] [103] attempted to recalibrate the HS coefficients in order to improve its performance. A large number of versions emerged to locally adapt the HS equation, amongst the PM which was lately adapted for using daily forecasted weather data for irrigation scheduling purposes [19]. However, Hargreaves and Allen (2003) [5] concluded that recalibrating the exponents and coefficients of the HS equation only increased the complexity of the equation. The HS method is usually preferred with respective to other more complicated equations since it requires only maximum and minimum air temperatures, which are available in most agro-climatic stations and can be measured with less error and by less trained individuals than the other climate variables used in combination equations. This is very important when solar radiation and wind speed data are lacking.

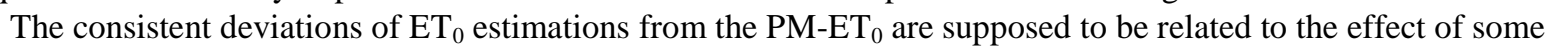
climatic variables amongst the wind speed, which affect greately $\mathrm{ET}_{0}$ computation. Discrepancies between $\mathrm{HS}$ and $\mathrm{PM}-\mathrm{ET}_{0}$ for example at Bizerte and Nabeul, is attributed to the high wind speed, particularly during spring when $\mathrm{ET}_{0}$ is higher. In our case, the observed disagreement between estimations may be partially due to not considering wind speed in the HS method. In other case studies, errors may be due to the lack of data and the use of empirical formula for estimating wind speed [89]. Raziei and Pereira (2013) [86] showed that using seasonal regional values as default wind speed values decreased the variance of residuals and the heteroscedasticity of regressions but increased the regression coefficients and therefore $\mathrm{ET}_{0}$ became over-estimated in the hot and windy locations (case of Bizerte and Nabeul). These authors conclude that, considering the need to minimize errors in estimating $\mathrm{ET}_{0}$ when only temperature data are available in areas where wind may play a major role, remains an open problem to further research developments.

The BC formula correlates well with PM at all Tunisian sites with $\mathrm{r}$ values ranging between 0.888 and 0.927 . However at seasonal scale it appears to be not appropriate for all growing periods. It performs well with PM during stages 1, 4 and 5 only for Nabeul and Sousse, which are coastal areas characterized by moderate rainfall amounts. These responses are perhaps due to the fact that the BC formula derived initially in farmers' fields under water stress conditions, and calculates an ET that is most closely related to the average county yields during the years the measurements were taken [104]. Therefore the values obtained in our case did not represent anon-water stressed condition. Razieia and Pereira (2013) [86] consider that the empirical relationship and the 
originally derived coefficients are nowadays outdated and invalid for today's agriculture production systems even with the subsequent changes that improved the BC-formula by adding more weather and crop variables, like that of Doorenbos and Pruitt (1974) [26] which is generally referred to as the FAO Blaney-Criddle (EtBC) including adjustment factors based on minimum relative humidity, sunshine, and daytime wind speed estimates. This modification to the BC formula was made to make it compatible with the modified Penman's reference ET equation.

Variations recorded when comparing the different methods of $\mathrm{ET}_{0}$ estimation indicate that there is no weather-based evapotranspiration equation that can be expected to predict evapotranspiration perfectly under every climatic situation due to simplification in formulation and errors in data measurement. According to Razieia and Pereira (2013) [86] it is probable that precision instruments under excellent environmental and biological management conditions will show the FAO Penman-Monteith equation to deviate at times from true measurements of grass $\mathrm{ET}_{0}$. However, the Expert Consultation agreed to use the hypothetical reference definition of the FAO Penman-Monteith equation as the definition for grass $\mathrm{ET}_{0}$ when deriving and expressing crop coefficients.

Local information on $\mathrm{K}_{\mathrm{c}}$ is scarce for olive, and mainly obtained from ET measurements by using the soil water balance method [76]. Orgaz et al., (2006) [18] reported crop coefficients for olive varying from 0.45 to 0.75 in different locations which are far below the values of annual crops, typically varying from 1.0 to 1.2 [26]. For central Tunisia, Braham and Boussadia (2013) [96] found values of 0.46 during the flowering and fruit set periods. Villalobos et al., (2000) [13] found an average annual crop coefficient of 0.62 which is considered rather low due to the low ground cover and to the enhanced control of canopy conductance by stomatal responses to VPD. These authors showed that the crop coefficient will vary among locations and even among years and seasons depending on soil humectation (rainfall, irrigation), solar radiation and reference evapotranspiration (ET), because this coefficient was derived under non-stressed conditions where water, fertilizer, insects, and salinity do not limit crop growth and production. However, in many cases these non-stressed conditions were not met when deriving the crop coefficients and consequently, the $\mathrm{K}_{\mathrm{c}}$ values have been adjusted upward as new measurements of Et have occurred under better irrigation scheduling conditions in the research fields [27] [37].

The variability of $\mathrm{K}_{\mathrm{c}}$ makes difficult to apply the FAO method to locations where no experimental information exists. So it is desirable to have a method that estimates directly the actual ET consistently well. In addition, the crop coefficient concept has not only the problem of it being unique to the reference ET formula use but the change in the crop coefficient over time can be a function of days since planting, percent cover or growing degree-days. Variations in $\mathrm{K}_{\mathrm{c}}$ and ETc estimates are also inherent to differences in resistance to transpiration, crop height, crop roughness, ground cover and crop rooting characteristics which explain the different ET levels in different types of environmental conditions for identical crop. Thus the crop variety and development stage should be considered when assessing the evapotranspiration from crops grown in large, well-managed fields. Additional consideration should be given to the range of management practices that act on the climatic and crop factors affecting the ET process. Cultivation practices and the type of irrigation method can affect the crop characteristics and the wetting of the soil. These results indicate that the use of no adequate method to estimate reference evapotranspiration for ETc estimation allowed overestimating or underestimating the water requirements; future research is needed to reconcile which should be the standard method of calculating the change in the crop coefficient over time. Recent works on plant water use showed that integrating daily sap flow is a very good way to establish the connection between the reference evapotranspiration and the individual plant water use [51] [99]. The method was proven to be valuable and valid for canopies with different sizes, exposure and environments. Masmoudi-Charfi et al., (2012) [105], by using the sap flow technique of Granier (1985) [91], found values of $\mathrm{K}_{\mathrm{c}} \mathrm{x} \mathrm{K}_{\mathrm{r}}$ of 0.53 for six-years old trees cultivated in North Tunisia, while Braham and Boussadia (2013) [96] adopting the same technique found specific values ranging between 0.46 and 0.51 for the period of flowing and early fruit development (April-May) for olive orchards cultivated in central Tunisia.This approach eliminates the need of the traditional crop coefficient scheme and future research is needed to reconcile which should be the standard method of calculating the change in the crop coefficient over time. It is desirable to have a method that estimates the $(E T c)$ consistently well.

Results relative to rainfall distribution show large annual and seasonal variability. Precipitation occurs sporadically, particularly in the centre and southern areas. Annual precipitations computed, from 1901 to 2000 over 99 years long period varied from less than $200 \mathrm{~mm}$ at Gabes to more than $600 \mathrm{~mm}$ at Bizerte and Béja. The lowest amount was obtained for the regions of Sidi-Bouzid located at the Center of Tunisia in the western area. 
At a seasonal scale, the rainiest periods are December-February for Béja-Tunis-Bizerte and September-November for the sites of Gabes, Sidi Bouzid, Sousse and Nabeul with similar trends for rainfall frequency. The autumnal and winter amounts are equivalent for Nabeul. The driest period is that of July-August for all sites. Minimum variations were observed during the summer period, in June (Nabeul, Sidi Bouzid) or July (Tunis, Sousse, Gabes) depending on site specificities.

On the basis of annual rainfall amounts and $\mathrm{ET}_{0}$-Thornthwaite estimates, cities of study were classified by using the UNEP aridity index. Values show that Béja and Bizerte as well as Tunis, Nabeul and Sousse have semi-arid climate with IA ranging between 0.20 and 0.43, while Gabes and Sidi-Bouzid are characterized by typical arid-climate with IA of 0.11 and 0.15 respectively, in spite of their location, since Gabes is a coastal town and Sidi Bouzid a western area located at $314 \mathrm{~m}$ of altitude. These results show that Tunisia is not concerned with humid and sub-humid climates when the IA is considered to climatically classify these regions, although some published papers considered the region of Kroumirie, extreme NW of Tunisia as humid area [41], while arid and semi-arid climates dominate the central and southern landscape. Also, although Bizerte, a coastal region, has a relatively high annual precipitation accompanied with cold winters, it is not considered as a sub-humid region. Its AI is close to that provided for Béja, a continental area of NW Tunisia, situated at $144 \mathrm{~m}$ of altitude.

These conditions make yields of olive orchards highly dependent on rainfall amounts and specially their distribution, resulting in a recurring deficiency of soil moisture and variable yields. Indeed, olive production varies from one year to another by a factor of five depending on the amount of rainfall and fall's timing. This situation is uncomfortable for Tunisia because olive production is vital to national economy, playing a key role in maintaining social stability and accounts for a large share of employment (30 millions/year). To face this problem, adequate water conservation strategies have been developed since many centuries and most of them have focused on improving the performance of irrigation systems or on adapting crop management systems to reduce the need for irrigation water particularly during summer months. But, at this time, there was no any fundamental or technical research to determine the effective water needs of olive orchards. First studies begin in Tunisia during the seventeenths [64]. Yield-enhancing techniques have been adopted at different scales to ensure the best use of natural water resources, ranging from modern irrigation techniques (drip irrigation and fertigation) to high yielding cultivars grown with high levels of inputs and with densities ranging between 300 and more than 1250 plants/ha. Many research studies show that in environments characterized by alternating wet and dry seasons, adding small amounts of water during the growing season can increase remarkably water productivity [14] [40] [51] [52] [76] [85] [106]. However, this potential of supplemental irrigation must be explored to make better use of the limited resources available, how we can use this fresh water for irrigating olive species which is considered for a long time as a tolerant crop supporting water shortage, vegetating and producing even with very low amounts of water. Nowadays, orchadists, conscious that olive industry is an obvious choice to improve agriculture, take to be informed about the crop water management and how to determine precisely and judiciously water needs for a better use efficiency. To help orchardists, a technical paper has been prepared and widely distributed in 2006 [107], presenting the crop water needs of olive trees depending on soil coverage, age and sites of olive cultivation. In this paper the FAO-PM method was used to compute $\mathrm{ET}_{0}$ with average climatic data recorded over a twenty-year long period.

Annual course of ETC computed with the PM method shows values ranging between $300 \mathrm{~mm}$ for young plantations and up to $800 \mathrm{~mm}$ for adult trees following. Highest ETC estimates are those recorded for Gabes, ranging between $335 \mathrm{~mm}$ and $894 \mathrm{~mm}$ depending on age. Minimum yearly values are recorded for Béja varying from $282 \mathrm{~mm}$ and $752 \mathrm{~mm}$. Lysimetric values determined by Nasr (2002) [1] representing the effective need of water are lower than ETC computations (ETC-PM) for Tunis, Nabeul, Sousse and Gabes, which are coastal areas. Annual ratios between the lysimetric values and ETc range between 0.74 and 0.96 for these areas and approximate the unit for both Béja and Sidi Bouzid. At seasonal scale, results showed that ETc increases following season in response to the increasing leaf area, varying for all stations from $15 \mathrm{~mm}$ to $61 \mathrm{~mm}$ in March, from $87 \mathrm{~mm}$ to 254 $\mathrm{mm}$ for the coastal areas and from $90 \mathrm{~mm}$ to $266 \mathrm{~mm}$ for the continental locations from April to November. In most cases and particularly for adult plantations cultivated in Centre and South Tunisia, rainfall amounts didn't meet these water needs. Estimates of seasonal values of (ETC-P), showed negatives values. The deficit of water is present even for young plantations inspite of their low water needs. Rainfall amounts were unable to cover the needs of water for this specie during the period of May-September, i.e. during fruit growth, the most important 
period that determines the production level. These amounts should be supplied necessary by irrigation. The lowest deficit is that provided for Béja and the highest is observed for Gabes. At annual scale, values of (ETc-P) are positive for Tunis, Nabeul, Sousse, Bizerte and Beja when young olive plantations are considered. For adult trees, values are positive only for Tunis, Bizerte and Béja. This last location is the only case where water needs are covered for olive trees aged 6 to 10 years. So there is a need for irrigating olive plantations aging more than 5 years and especially when olive is cultivated in the western areas. Irrigation is needed during the growing fruit period but also during the other seasons, when shoots grow. It is also necessary during "on" and "off” years. On the other hand the curves relative to rainfall distribution established for the different periods of growing give precious quantitative and qualitative information about water supplies: how irrigation can be made and at which amounts. Indeed, it appears from these results based on the seasonal rainfall frequencies and water needs computed with the PM formulae that irrigation supply is necessary all time for trees aging more than 10 years even for the rainiest locations as Bizerte and Béja where $20 \%$ only of the water needs are satisfied by rainfall. For younger plantations, irrigation becomes necessary beginning from the second period of development, i.e. AprilJune for Bizerte, Béja, Nabeul and Tunis. For the other stations, and particularly for Gabes and Sidi-Bouzid, irrigation is necessary for both young and old trees during the early spring period. If the requested amounts are not applied, many problems can arise affecting shoot growth [54], root development, water mineral uptakes [108] [109], fructification [61], olive maturation [74] and production [73] [85] [110], but also the water use efficiency. However, recent studies show that we can reduce water supplies during some periods without affecting production or fruit size, through application of the concept of deficit irrigation [50] [55] [56] [111]-[115]. Furthermore, a certain lack of water is appreciated and can improve substantially fructification and oil synthesis, but only if water is applied at specific stages [60] [116].

\section{Conclusions}

Based on a careful analysis of the history and applications of empirical formula for $\mathrm{ET}_{0}$ computation, their accuracy have been assessed against the $\mathrm{ET}_{0}-\mathrm{PM}$ formula, showing an adequateness of using some of them in Tunisia for different climatic sites. Good relationships were observed between $\mathrm{ET}_{0}-\mathrm{PM}$ estimates and those issued from Ivanov, Turc and HS methods, confirming the previous referred conclusion, which indicates that $\mathrm{ET}_{0}$ can be estimated with a specific formula even when climatic data are lacking. Each region may have an appropriate alternative for $\mathrm{ET}_{0}$ estimation. This may concern even the remote stations having only minimum and maximum temperature records.

Adequate estimation of $\mathrm{ET}_{0}$ is of great importance in agricultural and hydrological studies, water resources and watershed management. In particular, it is required for supporting irrigation scheduling, drought management and climate change studies. In this work, irrigation water needs of olive obtained from $\mathrm{ET}_{0}-\mathrm{PM}_{\mathrm{P}}$ computation were determined following sites of olive production, age of the orchard and the growing periods by associating them to the rainfall distribution functions. This allowed us to determine the case studies where irrigation is needed. However, despite a quite good performance of the PM-equation in most applications, and the fact that it is appropriate for a wide range of climates and sites, particularly when it is used for ETc estimation and irrigation scheduling purposes, using this method may confront users with the lack of information on radiation and $E T c$. It is thus necessary to adjust them with regard to the local conditions, and particularly in precising the correct values of $E T c$, which should be determined for all growing periods because the crop coefficient concept has not only the problem of it being unique to the reference ET formula use but the change in ETc values over time can be a function of days since planting, percent cover soil, humectation, vapour pressure deficit (VPD), solar radiation. Additional research is needed on developing specific crop coefficients that use the PM-equation when calculating ET and a standardized method of calculating the time base for the crop coefficients preferably based on a growing degree day concept. Also, applying irrigation amounts on the basis of $\mathrm{ET}_{0}$ - $\mathrm{PM}$ formula needs necessary determination of the effective rainfall amounts which is not easy to measure and many studies use approximate method for its calculation. It remains a big challenge.

Herefore, to have a reliable estimation of $\mathrm{ET}_{0}$ at a fine spatial resolution over the country, it is important to use accurate methods requiring limited weather data that can be available in a dense network through the country as it is the case for temperature. Indeed, the stations recording the climate variables needed for $\mathrm{ET}_{0}$-PM estimation are very sparse and in many cases have incomplete records, particularly in the central and southern 
areas where the Tunisian deserts are situated. That's why to our best knowledge, this work with that of Nasr (2002) [1] is the only one that has estimated $\mathrm{ET}_{0}$ for the whole country, but we didn't test the possible advantages in using calibrated values for the radiation adjustment coefficient or temperature adjustment for dew point temperature estimation as proposed by Allen (1996) [2]. This calibration is therefore a line to be explored.

\section{Acknowledgements}

Authors would like to thank Andolsi Shourouk for her assistance. Computation of $\mathrm{ET}_{0}$ was supported by this student. Thanks also to Mrs Chaabouni-Hadjtaieb Monia and Pr. Slimani at INAT.

\section{References}

[1] Nasr, Z. (2002) Mesures et estimations de l'évapotranspiration de référence en Tunisie. Annales de l'INRAT, 75, 241256.

[2] Allen, R.G. (1996) Assessing Integrity of Weather Data for Reference Evapotranspiration Estimation. Journal of Irrigation and Drainage Engineering, 122, 97-106. http://dx.doi.org/10.1061/(ASCE)0733-9437(1996)122:2(97)

[3] Hargreaves, G.H. and Samani, Z.A. (1982) Estimating Potential Evapotranspiration. Journal of the Irrigation and Drainage Division, 108, 225-230.

[4] Hargreaves, G.H. and Samani, Z.A. (1985) Reference Crop Evapotranspiration from Temperature. Applied Engineering in Agriculture, 1, 96-99. http://dx.doi.org/10.13031/2013.26773

[5] Hargreaves, G.H. and Allen, R.G. (2003) History and Evaluation of Hargreaves Evapotranspiration Equation. Journal of Irrigation and Drainage Engineering, 129, 53-63. http://dx.doi.org/10.1061/(ASCE)0733-9437(2003)129:1(53)

[6] Rana, G. and Katerji, N. (2000) Measurement and Estimation of Actual Evapotranspiration in the Field under Mediterranean Climate: A Review. European Journal of Agronomy, 13, 125-153. http://dx.doi.org/10.1016/S1161-0301(00)00070-8

[7] Allen, R.G., Jensen, M.E., Wright, J.L. and Burman, R.D. (1989) Operational Estimates of Reference Evapotranspiration. Agronomy Journal, 81, 650-662. http://dx.doi.org/10.2134/agronj1989.00021962008100040019x

[8] Allen, R.G., Pereira, L.S., Raes, D. and Smith, M. (1998) Crop Evapotranspiration, Guidelines for Computing Crop Water Requirements. Irrigation and Drainage Paper 56, FAO, Rome, 300.

[9] Habaieb, H. and Masmoudi-Charfi, C. (2003) Calcul des besoins en eau des principales cultures exploitées en Tunisie: Estimation de l'évapotranspiration de référence par différentes formules empiriques. Cas des régions de Tunis, Béja et Bizerte, Sécheresse, 14, 1-9.

[10] Sammis, T.W., Wang, J. and Miller, D.R. (2011) The Transition of the Blaney-Criddle Formula to the Penman-Monteith Equation in the Western US. Journal of Service Climatology, 5, 1-11. www.journalofserviceclimatology.org

[11] Denden, M. and Lemeur, R. (1999) Mesure de la transpiration par le modèle de Penman-Monteith. Sécheresse, 10, 3944.

[12] Pereira, L.S., Perrier, A., Allen, R.G. and Alves, I. (1999) Evapotranspiration: Review of Concepts and Future Trends. Journal of Irrigation and Drainage Engineering, 125, 45-51. http://dx.doi.org/10.1061/(ASCE)0733-9437(1999)125:2(45)

[13] Villalobos, F.J., Orgaz, F., Testi, L. and Fereres, E. (2000) Measurement and Modeling of Evapotranspiration of Olive (Olea europaea L.) Orchards. European Journal of Agronomy, 13, 155-163. http://dx.doi.org/10.1016/S1161-0301(00)00071-X

[14] Fernández, J.E., Palomo, M.J., Díaz-Espejo, A., Clothier, B.E., Green, S.R., Girón, I.R. and Moreno, F. (2001) HeatPulse Measurements of Sap Flow in Olives for Automating Irrigation: Tests, Root Flow and Diagnostics of Water Stress. Agricultural Water Management, 51, 99-123. http://dx.doi.org/10.1016/S0378-3774(01)00119-6

[15] Droogers, P. and Allen, R.G. (2002) Estimating Reference Evapotranspiration under Inaccurate Data Conditions. Irrigation and Drainage Systems, 16, 33-45. http://dx.doi.org/10.1023/A:1015508322413

[16] Allen, R.G., Pruitt, W.O., Wright, J.L., Howell, T.A., Ventura, F., Snyder, R., Itenfisu, D., Steduto, P., Berengena, J., Baselga, J., Smith, M., Pereira, L.S., Raes, D., Perrier, A., Alves, I., Walter, I. and Elliott, R. (2006) A Recommendation on Standardized Surface Resistance for Hourly Calculation of Reference ETo by the FAO56 PM-Method. Agricultural Water Management, 81, 1-22. http://dx.doi.org/10.1016/j.agwat.2005.03.007

[17] Gong, L.B, Xu, C.Y., Chen, D.L., Halldin, S. and Chen, Y.D. (2006) Sensitivity of the Penman-Monteith Reference Evapotranspiration to Key Climatic Variables in the Changjiang (Yangtze River) Basin. Journal of Hydrology, 329, 620-629. http://dx.doi.org/10.1016/j.jhydrol.2006.03.027 
[18] Orgaz, F., Testi, L., Villalobos, F.J. and Fereres, E. (2006) Water Requirements of Olive Orchards. Determination of Crop Coefficients for Irrigation Scheduling. Irrigation Science, 24, 77-84. http://dx.doi.org/10.1007/s00271-005-0012-x

[19] Cai, J.B., Liu, Y., Lei, T.W. and Pereira, L.S. (2007) Estimating Reference Evapotranspiration with the FAO PenmanMonteith Equation Using Daily Weather Forecast Messages. Agricultural and Forest Meteorology, 145, 22-35. http://dx.doi.org/10.1016/j.agrformet.2007.04.012

[20] Gavilán, P., Berengena, J. and Allen, R.G. (2007) Measuring versus Estimating Net Radiation and Soil Heat Flux: Impact on Penman-Monteith Reference ET Estimates in Semiarid Regions. Agricultural Water Management, 89, $275-$ 286. http://dx.doi.org/10.1016/j.agwat.2007.01.014

[21] López-Moreno, J.I., Hess, T.M. and White, S.M. (2009) Estimation of Reference Evapotranspiration in a Mountainous Mediterranean Site Using the Penman-Monteith Equation with Limited Meteorological Data. Pirineos, 164, 7-31. http://dx.doi.org/10.3989/pirineos.2009.v164.27

[22] Gocic, M. and Trajkovic, S. (2010) Software for Estimating Reference Evapotranspiration Using Limited Weather Data. Computers and Electronics in Agriculture, 71, 158-162. http://dx.doi.org/10.1016/j.compag.2010.01.003

[23] Kra, E.Y. (2010) An Empirical Simplification of the Temperature Penman-Monteith Model for the Tropics. Journal of Agricultural Science, 2, 162-171.

[24] Tabari, H. (2010) Evaluation of Reference Crop Evapotranspiration Equations in Various Climates. Water Resources Management, 24, 2311-2337. http://dx.doi.org/10.1007/s11269-009-9553-8

[25] Allen, R.G., Pereira, L.S., Howell, T.A. and Jensen, M.E. (2011) Evapotranspiration Information Reporting: I. Factors Governing Measurement Accuracy. Agricultural Water Management, 98, 899-920. http://dx.doi.org/10.1016/j.agwat.2010.12.015

[26] Doorenbos, J. and Pruitt, W.O. (1974) Guidelines for Predicting Crop Water Requirements. FAO Irrigation and Drainage Paper 24, Rome, 179 p.

[27] Jensen, M.E., Burman, R.D. and Allen, R.G. (1990) Evapotranspiration and Irrigation Water Requirements. ASCE Manuals and Reports on Engineering Practice, 332, American Society of Civil Engineers, New York, 360.

[28] Er-raki, S., Chehbouni, G., Guemouria, N., Ezzahar, J., Duchemin, B., Boulet, G., Hadria, R., Lakhal, A., Chehbouni, A. and Rodriguez, J.C. (2004) Measurement of Evapotranspiration and Development Of Crop Coefficients of Olive (Olea europaea L.) Orchards in Semi Arid Region (Marrakech, Morocco). Projet INCO-WADEMED Actes du Seminaire Modernisation de l'Agriculture Irriguée, Rabat, du 19 au 23 avril 2004.

[29] Annandale, J.G., Jovanovic, N.Z., Benadé, N., Bchir, A., Boussadia, O., Lemeur, R. and Braham M. (2013) Water Use in Olive Orchards Estimated by Physiologic and Climatic Methods in Tunisia. European Scientific Journal, 9.

[30] Popova, Z., Kercheva, M. and Pereira, L.S. (2006) Validation of the FAO Methodology for Computing ET $_{0}$ with Missing Climatic Data. Application to South Bulgaria. Irrigation and Drainage, 55, 201-215. http://dx.doi.org/10.1002/ird.228

[31] Jabloun, M. and Sahli A. (2008) Evaluation of FAO-56 Methodology for Estimating Reference Evapotranspiration Using Limited Climatic Data Application to TUNISIA. Agricultural Water Management, 95, 707-715. http://dx.doi.org/10.1016/j.agwat.2008.01.009

[32] Martinez, C.J. and Thepadia, M. (2010) Estimating Reference Evapotranspiration with Minimum Data in Florida. Journal of Irrigation and Drainage Engineering, 136, 494-501. http://dx.doi.org/10.1061/(ASCE)IR.1943-4774.0000214

[33] Nandagiri, L. and Kovoor, G.M. (2005) Sensitivity of the Food and Agriculture Organization Penman-Monteith Evapotranspiration Estimates to Alternative Procedures for Estimation of Parameters. Journal of Irrigation and Drainage Engineering, 131, 238-248. http://dx.doi.org/10.1061/(ASCE)0733-9437(2005)131:3(238)

[34] Jensen, D.T., Hargreaves, G.H., Temesgen, B. and Allen, R.G. (1997) Computation of ET $_{0}$ under Nonideal Conditions. Journal of Irrigation and Drainage Engineering, 123, 394-400. http://dx.doi.org/10.1061/(ASCE)0733-9437(1997)123:5(394)

[35] Thornthwaite, C.W. (1948) An Approach toward a Rational Classification of Climate. Geographical Review, 38, 5594. http://dx.doi.org/10.2307/210739

[36] Allen, R.G., Smith, M., Perrier, A. and Pereira L.S. (1994) An Update for the Definition of Reference Evapo-transpiration. ICID Bul., 43, 1-34.

[37] Martí, P. and Zarzo, M. (2012) Multivariate Statistical Monitoring of $\mathrm{ET}_{0}$ : A New Approach for Estimation in Nearby Locations Using Geographical Inputs. Agricultural and Forest Meteorology, 152, 125-134. http://dx.doi.org/10.1016/j.agrformet.2011.08.008

[38] Laroussi, C. and Habaieb, H. (1993) Gestion des ressources en eau en conditions d'aridité, cas de la Tunisie. Etat de 
l'agriculture en Méditerranée: Ressources en eau: Développement et gestion dans les pays méditerranéens. Bari: CIHEAM, Cahiers Options Méditerranéennes, 92-108.

[39] Kassas, M. (2005) Aridity, Drought and Desertification. Chapter 7, 95-110. Export Marketing of Gum Arabic from Sudan, World Bank Policy Note March 2007. www.afedonline.org/afedreport/english/book7.pdf http://siteresources.worldbank.org/INTAFRMDTF/Resources/Gum_Arabic_Policy_Note.pdf

[40] Ben Mechlia, N., Oweis, T., Masmoudi, M., Khatteli, H., Ouessar, M., Sghaier, N., Anane, M. and Sghaier, M. (2009) Assessment of Supplemental Irrigation and Water Harvesting Potential: Methodologies and Case Studies from Tunisia. ICARDA, Aleppo, 36.

[41] Hamza, M. (2009) La politique de l'eau en Tunisie. Conférence Régionale sur la gouvernance de l'eau, Echanges d'expériences entre l'OCDE et les pays arabes, CITET-Tunis, 8-9 Juillet 2009.

[42] Ben Ahmed, C., Ben Rouina, B. and Boukhris, M. (2007) Effect of Water Deficit on Olive Trees cv. Chemlali under Field Conditions in Arid Region in Tunisia. Scientia Horticulturae, 113, 267-277. http://dx.doi.org/10.1016/j.scienta.2007.03.020

[43] Ghrab, M., Gargouri, K. and Ben Mimoun, M. (2008) Long-Term Effect of Dry Conditions and Drought on Fruit Trees Yield in Dryland Areas of Tunisia. Options Méditerranéennes, Séries A, 80, 107-112.

[44] Ben Rouina, B., Trigui, A., D’andria, R., Boukhriss, M. and Chaieb, M. (2007) Effects of Water Stress and Soil Type on Photosynthesis, Leaf Water Potential and Yield of Olive Trees (Olea europaea L. cv Chemlali Sfax). Australian Journal of Experimental Agriculture, 47, 1484-1490. http://dx.doi.org/10.1071/EA05206

[45] Ben Ahmed, C., Ben Rouina, B., Sensoy, S., Boukhris, M. and Abdallah, F.B. (2009) Saline Water Irrigation Effects on Antioxidant Defense System and Proline Accumulation in Leaves and Roots of Field-Grown Olive. Journal of Agricultural and Food chemistry, 57, 11484-11490. http://dx.doi.org/10.1021/jf901490f

[46] Bedbabis, S., Ben Rouina, B. and Boukhris, M. (2010) The Effect of Waste Water Irrigation on the Extra Virgin Olive Oil Quality from the Tunisian Cultivar Chemlali. Scientia Horticulturae, 125, 556-561. http://dx.doi.org/10.1016/j.scienta.2010.04.032

[47] Guerfel, M., Baccouri, B., Boujnah, D. and Zarrouk, M. (2007) Seasonal Changes in Water Relations and Gas Exhange in Leaves of Two Tunisian Olives (Olea europaea L.) Cultivars under Water Deficit. The Journal of Horticultural Science \& Biotechnology, 82, 721-726.

[48] Guerfel, M., Baccouri, B., Boujnah, D. and Zarrouk, M. (2007) Evaluation of Morphological and Physiological Traits for Drought Tolerance in 12 Tunisian Olive Varieties (Olea europaea L.). Journal of Agronomy, 6, 356-361. http://dx.doi.org/10.3923/ja.2007.356.361

[49] Boussadia, O., Mechri, B., Benmariem, F., Boussitta, W., Braham, M. and Ben Elhadj, S. (2008) Response to Drought of Two Olive Tree Cultivars (cv Koroneki and Meski). Scientia Horticulturae, 116, 388-393. http://dx.doi.org/10.1016/j.scienta.2008.02.016

[50] Fernandez, J.E. (2006) Irrigation Management in Olive, Instituto de Recursos Naturales y Agrobiologia de Sevilla (IRNAS), 295-305.

[51] Chehab, H., Mechri, B., Benmariem, F., Hammami, M., Ben Hadj, S. and Braham, M. (2009) Effect of Different Irrigation Regimes on Carbohydrate Partitioning in Leaves and Wood of Two Table Olive Cultivars (Olea europaea L. cv. Meski and Picholine). Agricultural Water Management, 96, 293-298. http://dx.doi.org/10.1016/j.agwat.2008.08.007

[52] Dabbou, S., Chehab, H., Brahmi F., Esposto S., Elvaggini, R., Tatitcchi, A., Servili, M., Montedoro, G.F. and Hammami, M. (2010) Effect of Three Irrigation Regimes on Arbequina Olive Oil Produced under Tunisian Growing Conditions. Agricultural Water Management, 97, 763-768. http://dx.doi.org/10.1016/j.agwat.2010.01.011

[53] Masmoudi, M.M. and Ben Mechlia, N. (2003) Deficit Irrigation of Orchards. In: Hamdy, A., Ed., Regional Action Programme (RAP): Water Resources Management and Water Saving in Irrigated Agriculture (WASIA PROJECT), Bari: CIHEAM, 203-216, Options Méditerranéennes: Série B, Etudes et Recherches.

[54] Mezghani-Ayachi, M., Masmoudi-Charfi, C., Gouia, M. and Laabidi, F. (2012) Vegetative and Reproductive Behavior of Some Olive Tree Varieties (Olea europaea L.) under Deficit Irrigation Regimes in Semi-Arid Conditions of Central Tunisia. Scientia Horticulturae, 146, 143-152. http://dx.doi.org/10.1016/j.scienta.2012.07.030

[55] Masmoudi-Charfi, C. and Mezghani-Ayachi, M. (2013) Response of Olive Trees to Deficit Irrigation Regimes: Growth, Yield and Water Relations. Agricultural Research Updates, Vol. 6, Nova Sciences Publishers, New York.

[56] Fernandez, J.E., Paloma, M.J., Diaz-Espejo, A. and Giron, I.F. (2003) Influence of Partial Soil Wetting on Water Relation Parameters of the Olive Tree. Agronomie, 23, 545-552. http://dx.doi.org/10.1051/agro:2003031

[57] Ghrab, M., Gargouri, K., Bentaher, H., Chartzoulakis, K., Ayadi, M., Ben Mimoun, M., Masmoudi, M., Ben Mechlia, N. and Psarras, G. (2013) Water Relations and Yield of Olive Tree (cv. Chemlali) in Response to Partial Root-Zone Drying (PRD) Irrigation Technique and Salinity under Arid Climate. Agricultural Water Management, 123, 1-11. http://dx.doi.org/10.1016/j.agwat.2013.03.007 
[58] Piedra, P.A., Humanes, G.J., Munoz-Cobo, P. and Martin, S. (1997) Plantations à haute densité. Concepts nécessaires. Olivae, 69.

[59] Larbi, A., Ayadi, M., Ben Dhiab, A. and Msallem, M. (2009) Comparative Study of Tunisian and Foreign Olive Cultivars Sustainability for High Density Planting System. Olivebioteq, Sfax-Tunisia, 177-181.

[60] Rallo, L. (1998) Fructification y Produccion, in El Cultivo del olivo. Junta de Andalucia y Grupo Mundi-Prensa, 107136.

[61] Rallo, L. and Rapoport, H.F. (2001) Early Growth and Development of the Olive Fruit Mesocarp. Journal of Horticultural Science and Biotechnology, 76, 408-412.

[62] Masmoudi-Charfi, C. (2013) Growth of Young Olive Trees. Special Issue on Plant Growth and Development. American Journal of Plant Sciences, 4, 1316-1344. http://www.scirp.org/journal/ajps

[63] Sanz-Cortès, F., Martinez-Calvo, J., Badenes M.L., Bleiholder, H., Hack, H., Llacer, G. and Meier, U. (2002) Phenological Growth Stages of Olive Trees (Olea europaea). Annals of Applied Biology, 140, 151-157. http://dx.doi.org/10.1111/j.1744-7348.2002.tb00167.x

[64] Ben Mechlia, N. and Hamrouni, A. (1978) Alternance et production potentielle chez l’olivier irrigué. Séminaire International sur l'olivier et autres plantes oléagineuses cultivées en Tunisie, Mahdia, 3-7 Juillet 1978, 199-208.

[65] Le Bourdelles, J. (1977) Irrigation par goutte à goutte en oléiculture, principe de la méthode, installation et fonctionnement. Olea, 24, 31-49.

[66] Bouaziz, E. (1983) Intensification et irrigation à l'eau saumâtre de l'olivier dans les grandes plaines du Centre Tunisien. Mémoire de $3^{\text {ème }}$ cycle de l'INAT, Oléiculture-Oléotechnie, 126 p.

[67] Chehab, H. (2007) Etude écophysiologique, agronomique, de production et relation source-puits chez l’Olivier de table en rapport avec les besoins en eau. Thèse de Doctorat en Sciences Agronomiques, Institut National Agronomique de Tunisie, Tunis.

[68] Masmoudi-Charfi, C., Masmoudi, M.M. and Ben Mechlia, N. (2004) Irrigation de l'olivier: Cas des jeunes plantations intensives. Revue Ezzaitouna, 10, 37-51.

[69] Masmoudi-Charfi, C., Masmoudi, M.M., Mahjoub, I. and Mechlia, N.B. (2007) Water Requirements of Individual Olive Trees in Relation to Canopy and Root Development. Options Méditerranéennes, Série B, Studies and Research, Vol. 1. CIHEAM. Proceedings of the International Conference on Water saving in Mediterranean Agriculture and Future Research Needs, Valenzano, 14-17 February 2007, 73-80.

[70] Masmoudi-Charfi, C., Ayach-Mezghani, M., Gouia, M., Labidi, F., Lamari, S., Ouled Amor, A. and Bousnina, M. (2010) Water Relations of Olive Trees Cultivated under Deficit Irrigation Regimes. Scientia Horticulturae, 125, 573578. http://dx.doi.org/10.1016/j.scienta.2010.04.042

[71] Michelakis, N. (1990) Yield Response of Table and Oil Olive Tree Varieties to Different Water Doses under Drip Irrigation. Acta Horticulturae, 286, 271-274.

[72] Michelakis, N. (1995) Effet des disponibilités en eau sur la croissance et le rendement des oliviers. Olivae, 56, 29-39.

[73] Sole Riera, M.A. (1990) The Influence of Auxilary Drip Irrigation with Low Quantities of Water on Olive Trees in Las Garrigas (Cv Arbequina). Acta Horticulturae, 286, 307-310.

[74] Inglese, P., Barone, E. and Gullo, G. (1996) The Effect of Complementary Irrigation on Fruit Growth, Ripening Patter and Soil Characteristics of Olive (Olea europaea L.) Cv. Carolea. Journal of Horticultural Science, 71, 257-263.

[75] Fernandez, J.E. and Moreno, F. (1999) Water Use by the Olive Tree. Journal of Crop Production, 2, 101-162. http://dx.doi.org/10.1300/J144v02n02_05

[76] Michelakis, N. (2000) Water Requirements of Olive Tree on the Various Vegetative Stages. Proceedings of the International Course on Water Management and Irrigation of Olive Orchards, Cyprus, April 2000, 39-49.

[77] Palomo, M.J., Moreno, F., Fernandez, J.E., Diaz-Espejo, A. and Giron, I.F. (2002) Determining Water Consumptive in Olive Orchards Using the Water Balance Approach. Agricultural Water Management, 55, 15-35. http://dx.doi.org/10.1016/S0378-3774(01)00182-2

[78] Masmoudi-Charfi, C., Masmoudi, M.M., Karray-Abid, J. and Ben Mechlia, N. (2012) The Sap Flow Technique: A Precise Means to Estimate Water Consumption of Young Olive Trees (Olea europaea L.). Chapter 2 in Irrigation Management Technologies and Environmentam Impact, Nova Sciences Publishers, New York. https://www.novapublishers.com/catalog/product_info.php.

[79] Cohen, Y. (1991) Determination of Orchard Water Requirement by a Combined Trunk Sap Flow and Meteorology Approach. Irrigation Science, 12, 93-98. http://dx.doi.org/10.1007/BF00190016

[80] Villagra, M.M., Bacchi, O.O.S., Tuon, R.L. and Reichardt, K. (1995) Difficulties of Estimating Evapotranspiration from the Water Balance Equation. Agricultural and Forest Meteorology, 72, 317-325.

http://dx.doi.org/10.1016/0168-1923(94)02168-J 
[81] Testi, L., Villalobos, F.J. and Orgaz, F. (2004) Evapotranspiration of a Young Irrigated Olive Orchard in Southern Spain. Agricultural and Forest Meteorology, 121, 1-18. http://dx.doi.org/10.1016/j.agrformet.2003.08.005

[82] Todorovic, M., Karic, B. and Pereira, L.S. (2013) Reference Evapotranspiration Estimate with Limited Weather Data across a Range of Mediterranean Climates. Journal of Hydrology, 481, 166-176. http://dx.doi.org/10.1016/j.jhydrol.2012.12.034.

[83] Masmoudi-Charfi, C. (2012) Quantitative Analysis of Soil Water Content in Young Drip Irrigated Olive Orchards. Advances in Horticultural Sciences, 26, 138-147.

[84] Caspari, H.W., Green, S.R. and Edwards, W.R.N. (1993) Transpiration of Well-Watered and Water-Stressed Asian Pear Trees as Determined by Lysimetry, Heat-Pulse, and Estimated by a Penman-Monteith Model. Agricultural and Forest Meteorology, 67, 13-27. http://dx.doi.org/10.1016/0168-1923(93)90047-L

[85] Moriana, A.F., Perez-Lopez, D., Gomez-Rio, A., Salvador, M., Olmedilla, N., Ribas, F. and Fregapane, G. (2006) Irrigation Scheduling for Traditional Low-Density Olive Orchards: Water Relations and Influence on Oil Characteristics.

[86] Razieia, T. and Pereira, L.S. (2013) Reference Estimation of $\mathrm{ET}_{0}$ with Hargreaves-Samani and FAO-PM Temperature Methods for a Wide Range of Climates in Iran. Agricultural Water Management, 121, 1-18. http://dx.doi.org/10.1016/j.agwat.2012.12.019

[87] Pereira, A.R., Green, E., Villa, N. and Nilson, A. (2005) Penman-Monteith Reference Evapotranspiration Adapted to Estimate Irrigated Tree Transpiration. Agricultural Water Management, 83, 153-161.

[88] Allen, R.G. (2002) Software for Missing Data Error Analysis of Penman-Monteith Reference Evapotranspiration. Irrigation Science, 21, 57-67. http://dx.doi.org/10.1007/s002710100047

[89] Moreno, F., Fernandez, J.E., Clothier, B.E. and Green, S.R. (1996) Transpiration and Root Water Uptake by Olive Trees. Plant and Soil, 184, 85-96. http://dx.doi.org/10.1007/BF00029277

[90] Abid-Karray, J. (2006) Bilan Hydrique d’un système de cultures intercalaires (Olivier-Culture maraîchère) en Tunisie Centrale: Approche expérimentale et essai de modélisation. Thèse de Doctorat, Université de Montpellier II, Montpellier, $172 \mathrm{p}$.

[91] Granier, A. (1985) Une nouvelle méthode pour la mesure des flux de sève brute dans le tronc des arbres. Annals of Forest Science, 42, 193-200. http://dx.doi.org/10.1051/forest:19850204

[92] Penman, H.L. (1948) Natural Evaporation from Open Water, Bare Soil, and Grass. Proceedings of the Royal Society, A193, 116-140. http://dx.doi.org/10.1098/rspa.1948.0037

[93] Priestley, C.H.B. and Taylor, R.J. (1972) On the Assessment of Surface Heat Flux and Evaporation Using Large Scale Parameters. Monthly Weather Review, 100, 81-92. http://dx.doi.org/10.1175/1520-0493(1972)100<0081:OTAOSH>2.3.CO;2

[94] Bonachela, S., Orgaz, F., Villalobos, F. and Fereres, J.E. (1999) Measurement and Simulation of Evaporation from Soil in Olive Orchards. Irrigation Science, 18, 205-211. http://dx.doi.org/10.1007/s002710050064

[95] L’olivier, C.O.I. (1997) Encyclopédie Mondiale de l’Olivier. Conseil oléicole international, Madrid, 479 p.

[96] Braham, M. and Boussadia, O. (2013) Annual Report of the National Institute of Olive Tree.

[97] INM (2013) National Institute of Meteorology. www.meteo.tn

[98] Victor, M. and San Diego, P. Potential Evapotranspiration by the Thornthwaite Method. State of University. Online_Thornthwaite: Potential Evapotranspiration by Thornthwaite Method.

[99] Yunusa, I.A.M., Walker, R.R., Loveys, B.R. and Blackmore, D.H. (2000) Determination of Transpiration in Irrigated Grapevines: Comparison of the Heat-Pulse Technique with Gravimetric and Micrometeorological Methods. Irrigation Science, 20, 1-8. http://dx.doi.org/10.1007/PL00006714

[100] Temesgen, B., Eching, S., Davidoff, B. and Frame, K. (2005) Comparison of Some Reference Evapotranspiration Equations for California. Journal of Irrigation and Drainage Engineering, 131, 73-84. http://dx.doi.org/10.1061/(ASCE)0733-9437(2005)131:1(73)

[101] Alkaeed, O., Flores, C., Jinno, K. and Tsutsumi, A. (2006) Comparison of Several Reference Evapotranspiration Methods for Itoshima Peninsula Area, Fukuoka, Japan. Memoirs of the Faculty of Engineering, Kyushu University, Vol. 66, Vngsas, Fukuoka, 1-14.

[102] Paredes, P. and Rodrigues, G.C. (2010) Necessidades de água para a rega de milho em Portugal Continental considerando condic, ões de seca. In: Pereira, L.S., Mexia, J.T. and Pires, CA.L., Eds., Gestão do Risco em Secas, Métodos, Tecnologias e Desafios, Edic ões Colibri e CEER, Lisboa, 301-320.

[103] Trajkovic, S. (2007) Hargreaves versus Penman-Monteith under Humid Conditions. Journal of Irrigation and Drainage Engineering, 133, 38-42. http://dx.doi.org/10.1061/(ASCE)0733-9437(2007)133:1(38)

[104] David, R.M. (2011) The Transition of the Blaney-Criddle Formula to the Penman-Monteith Equation in the Western 
United States. Journal of Service Climatology, 5, 1-11.

[105] Masmoudi-Charfi, C., Abid-Karray, J., Gargouri, K., Rhouma, A., Habaieb, H. and Daghari, H. (2012) Manuel d'Irrigation de l'Olivier, Techniques et Applications, Institut de l'Olivier, $110 \mathrm{p}$.

[106] Bonji, G. and Palliotti, A. (1994) Olive in Hand Book of Environmental Physiology of Fruit Crop. Anderson CRC Press Inc., Boca Raton, 165-187.

[107] Masmoudi-Charfi, C. (2006) Irrigation des plantations d’olivier. Document Technique, Institut de l’Olivier, Tunisie.

[108] Palese, A.M., Nuzzo, V., Dichio, B., Celano, G., Romano, M., Xiloyannis, C., Ferreira, M.I. and Jones, H.G. (2000) The Influence of Soil Water Content on Root Density in Young Olive Trees. Acta Horticulturae, 537, 329-336.

[109] Dichio, B., Romano, M., Nuzzo, V. and Xiloyannis, C. (2002) Soil Water Availability and Relationship between Canopy and Roots in Young Olive Trees (Cv. Coratina). Acta Horticulturae, 586, 255-258.

[110] Moriana, A.F., Orgaz, F., Pastor, M. and Fereres, E. (2003) Yield Response of a Mature Olive Orchard to Water Deficits. Journal of the American Society for Horticultural Science, 128, 425-431.

[111] Tognetti, R., D’Andria, R., Lavini, A. and Morelli, G. (2006) The Effect of Deficit Irrigation on Crop Yield and Vegetative Development of Olea europaea L. (cvs. Frantoio and Leccino). European Journal of Agronomy, 25, 356-364. http://dx.doi.org/10.1016/j.eja.2006.07.003

[112] Gucci, R., Lodolini, E. and Rapoport, H.F. (2007) Productivity of Olive Trees with Different Water Status and Crop Load. Journal of Horticultural Science and Biotechnology, 82, 648-656.

[113] Melgar, J.C., Mohamed, Y., Navarro, C., Parra, M.A., Benlloch, M. and Fernandez-Escobar, R. (2008) Long-Term Growth and Yield Responses of Olive Trees to Different Irrigation Regimes. Agricultural Water Management, 95, 968-972. http://dx.doi.org/10.1016/j.agwat.2008.03.001

[114] Iniesta, F., Testi, L., Orgaz, F. and Villalobos, F.J. (2009) The Effects of Regulated and Continuous Deficit Irrigation on the Water Use, Growth and Yield of Olive Trees. European Journal of Agronomy, 25, 258-265. http://dx.doi.org/10.1016/j.eja.2008.12.004

[115] Connor, D.J. and Fereres, E. (2005) The Physiology of Adaptation and Yield Expression in Olive. Horticultural Review, Vol. 31, John Wiley \& Sons, Inc., Hoboken.

[116] Boulouha, B. (1986) Croissance, Fructification et leur interaction sur la production chez la Picholine Marocaine, Olea, 17, 41-47.

\section{List of Abbreviations}

ASCE: American Society of Civil Engineers Standardized Reference ET equation.

BC: Blaney-Criddle formula for $\mathrm{ET}_{0}$ computation.

$\mathbf{c}_{\mathbf{p}}$ : specific heat of the air.

$\mathbf{C}_{\mathrm{TT}}, \mathbf{C}_{\mathrm{WT}}, \mathbf{C}_{\mathrm{HT}}, \mathbf{C}_{\mathrm{ST}}, \mathbf{C}_{\mathbf{R}}$ : functions of temperature, wind, relative humidity, insulation and elevation.

Chr. Harg.: Christiansen-Hargreaves method for $\mathrm{ET}_{0}$ computation.

$\mathbf{e}_{\mathbf{0}}$ : saturation vapor pressure $(\mathrm{kPa})$.

$\mathrm{e}_{\mathrm{a}}$ : actual vapor pressure $(\mathrm{kPa})$.

$\boldsymbol{e}_{\mathbf{0}}-\boldsymbol{e}_{\mathbf{a}}$ : vapor pressure deficit of the air $(\mathrm{kPa})$ and $\mathrm{e}_{\mathrm{a}}$ is actual vapor pressure $(\mathrm{kPa})$.

$\boldsymbol{e}_{\boldsymbol{o}}=0.5\left[\mathrm{e}_{0}\left\{\mathrm{~T}_{\max }\right\}+\mathrm{e}_{0}\left\{\mathrm{~T}_{\min }\right\}\right]$ and $\mathrm{e}_{\mathrm{a}}=\left[\mathrm{e}_{\mathrm{oTmax}} \mathrm{RH}_{\min }+\mathrm{e}_{\mathrm{oTmin}} \mathrm{RH}_{\max }\right] / 200$.

$\mathbf{E T}_{\mathbf{0}}$ : Reference evapotranspiration ( $\mathrm{mm} /$ day).

$\mathbf{E T}_{\mathbf{0}}-\mathbf{P M}$ or PM-ET $\mathbf{P}_{\mathbf{0}}$ : Reference evapotranspiration obtained from Penman-Monteith equation (mm).

ETc: Crop evapotranspiration (mm). 
ETc-PM: Crop evapotranspiration calculated on the basis of $\mathrm{ET}_{0}$ Penman-Monteith computation (mm).

ETC-P: Climatic water deficit (mm).

ET: Maximum daily, monthly or seasonal evapotranspiration determined under non-stressed conditions (mm).

E: Elevation.

EAG: Eagleman method for $\mathrm{ET}_{0}$ computation.

F: Rainfall frequency (\%).

FAO-PM: Penman-Monteith method of FAO.

G: Soil heat flux density $\left(\mathrm{MJ} \cdot \mathrm{m}^{-2} \cdot \mathrm{day}^{-1}\right)$, flux of heat into the soil, set equal to zero to represent the condition of an isolated tree.

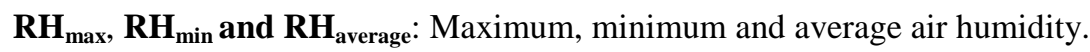

HS: Hargreaves-Samani formula for $\mathrm{ET}_{0}$ computation.

IA: Index of aridity.

INM: National Institute of Meteorology of Tunisia.

ETc: Crop coefficient.

$\mathbf{K}_{\mathbf{r}}$ : coefficient introduced to take into account the soil coverage.

LAI: Leaf area index.

N: Maximum sunshine durations (hours/day).

n: Actual sunshine durations (hours/month).

p: daylight hours monthly/annual daylight hours.

i: number of days/month.

P: Rainfall amount (mm)

PM: Penman-Monteith equation.

PMT: Penman Monteith Temperature method.

PO: Penman Original method for $\mathrm{ET}_{0}$ computation

$\mathbf{r}_{\mathrm{s}}$ and $\mathbf{r}_{\mathrm{a}}$ : bulk surface and aerodynamic resistances.

$\mathbf{R}_{\mathbf{a}}$ : atmospheric radiation $\left(\mathrm{Mj} / \mathrm{m}^{2} /\right.$ day $)$.

$\mathbf{R}_{\mathbf{n}}$ : net radiation at the crop surface $\left(\mathrm{MJ} \cdot \mathrm{m}^{-2} \cdot \mathrm{day}^{-1}\right), \mathrm{R}_{\mathrm{n}}$ is computed as the algebraic sum of the net short and long short radiations.

ST and SW: Hargreaves-Samani method for $\mathrm{ET}_{0}$ computation.

$\boldsymbol{T}$ : Tree transpiration (liters of water/day or $\mathrm{mm}$ ).

T: Mean daily air temperature at $2 \mathrm{~m}$ height $\left({ }^{\circ} \mathrm{C}\right), \mathrm{u}_{2}$ is wind speed at $2 \mathrm{~m}$ height $\left(\mathrm{m} \cdot \mathrm{s}^{-1}\right)$,

$\mathbf{T}_{\max }$ and $\mathbf{T}_{\text {min }}$ : maximum and minimum air temperatures $\left({ }^{\circ} \mathrm{C}\right)$,

$\mathrm{T}_{\mathrm{m}}$ or $\mathrm{T}_{\text {average: }}$ Mean daily air temperature ${ }^{\circ} \mathrm{C}$, with $\mathrm{T}:{ }^{\circ} \mathrm{F}=\left(\mathrm{T}\right.$ x 9/5) +32 with $\mathrm{T}_{\text {mean }}=0.5\left(\mathrm{~T}_{\max }+\mathrm{T}_{\min }\right)$

$\Delta \mathbf{T}: \mathrm{T}_{\max }-\mathrm{T}_{\min }$.

TW: Thornthwaite method for $\mathrm{ET}_{0}$ computation.

$\mathbf{U}_{2}$ : wind speed measured at $2 \mathrm{~m}$ height $(\mathrm{m} / \mathrm{s})$.

VPD: vapour pressure deficit $(\mathrm{kPa})$.

$\Delta$ : Slope of the saturated vapor pressure curve $\left(\mathrm{kPa} \cdot{ }^{\circ} \mathrm{C}^{-1}\right)$.

$\gamma$ : Psychrometric constant $\left(\mathrm{kPa}^{\circ}{ }^{\circ} \mathrm{C}^{-1}\right)$, was set constant and equal to $0.066 \mathrm{kPa} \cdot{ }^{\circ} \mathrm{C}^{-1}$ for all experiments.

Months:

Sept.: September.

Nov.: November.

Dec.: December.

Feb.: February. 
Scientific Research Publishing (SCIRP) is one of the largest Open Access journal publishers. It is currently publishing more than 200 open access, online, peer-reviewed journals covering a wide range of academic disciplines. SCIRP serves the worldwide academic communities and contributes to the progress and application of science with its publication.

Other selected journals from SCIRP are listed as below. Submit your manuscript to us via either submit@scirp.org or Online Submission Portal.
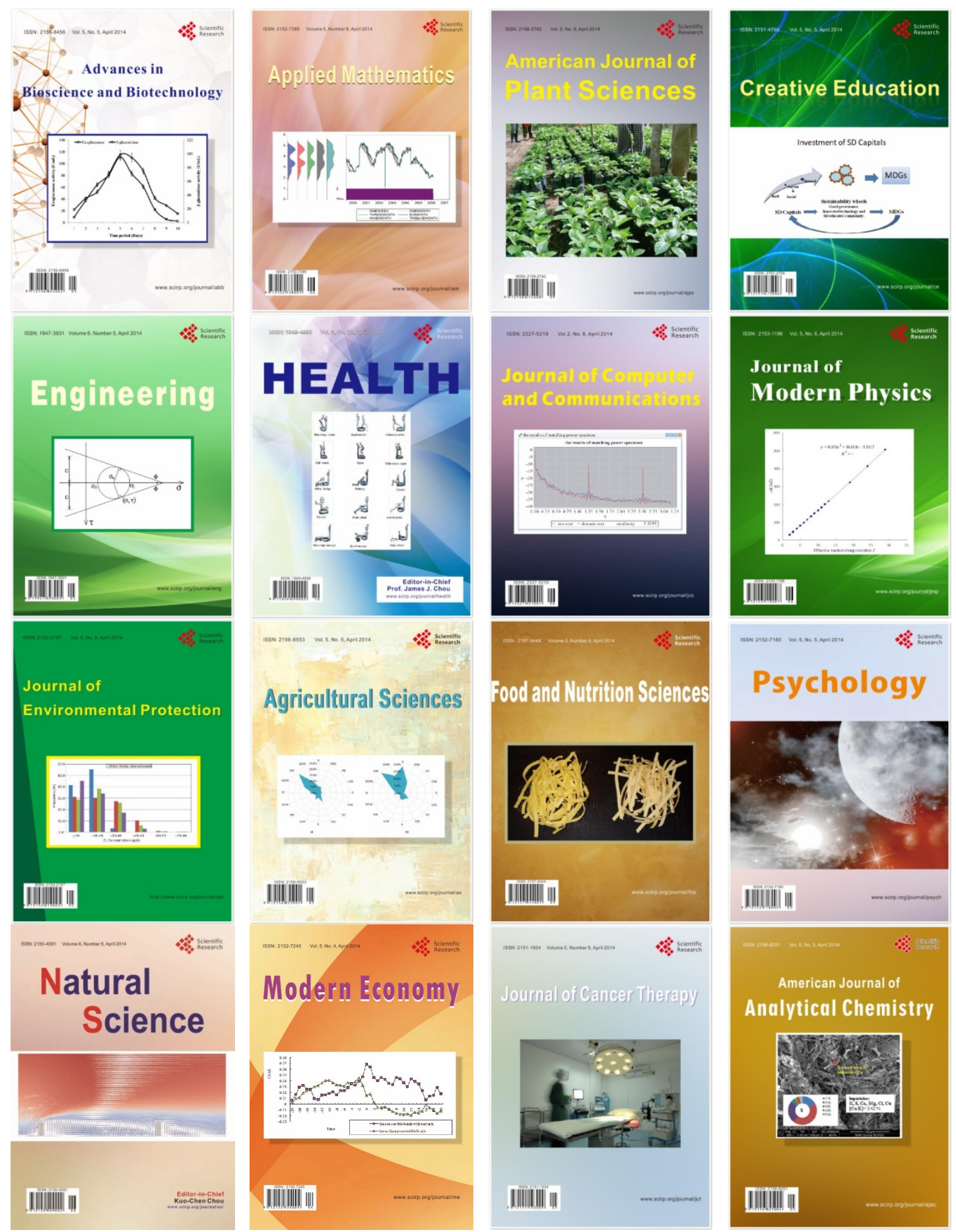